

\title{
Potential Effects of Low-Volume Effluent Discharges on Past-Practice Vadose Zone Contamination
}

\author{
L. B. Collard, J. D. Davis, D. B. Barnett
}

Westinghouse Hanford Company, Richland, WA 99352

U.S. Department of Energy Contract DE-AC06-87RL10930

$\begin{array}{lll}\text { EDT/ECN: } & 615736 & \text { UC: } 630 \\ \text { Org Code: } & 8 \text { H200 } & \text { Charge Code: } \\ \text { B\&R Code: } & \text { EW3130020 } & \text { Total Pages: } 96\end{array}$

Key Words: Numerical Modeling, Miscellaneous Streams, Past-Practice Effluent Discharges, Vadose Zone, Unsaturated Hydraulic Conductivity

Abstract: Collard, L. B., J. D. Davis, D. B. Barnett, 1996, Potential Effects of Low-Volume Effluent Discharges on Past Practice Vadose Zone Contamination: WHC-SD-LEF-ER-001, Westinghouse Hanford Company, Richland Washington.

This document estimates the behavior of extremely lowdischarges of water in the unsaturated zone in the vicinity of past-practice facilities.

TRADEMARK DISCLAIMER. Reference herein to any specific comercial product, process, or service by trade name, trademark, manufacturer, or otherwise, does not necessarily constitute or imply its endorsement, recommendation, or favoring by the United States Government or any agency thereof or $i$ ts contractors or subcontractors.

Printed in the United States of America. To obtain copies of this document, contact: WHC/BCS Document Control Services, P.O. Box 1970, Mailstop H6-08, Richland WA 99352, Phone (509) 372-2420. Fax (509) 376-4989.
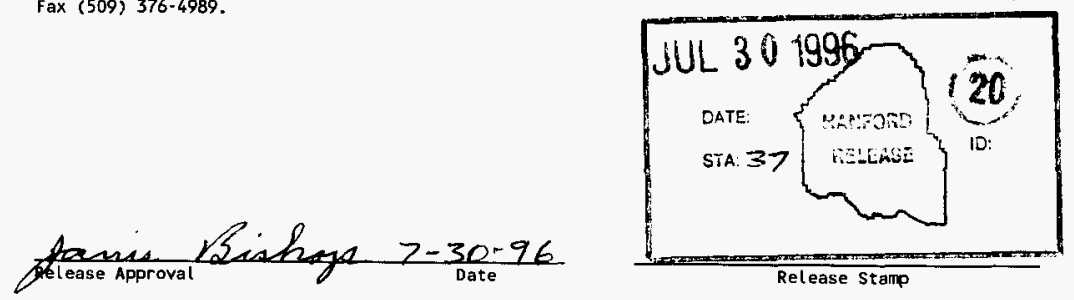
WHC-SD-LEF-ER-001, Rev. 0

POTENTIAL EFFECTS OF LOW-VOLUME EFFLUENT DISCHARGES ON PAST-PRACTICE VADOSE ZONE CONTAMINATION 


\section{CONTENTS}

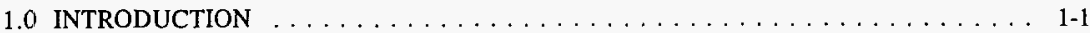

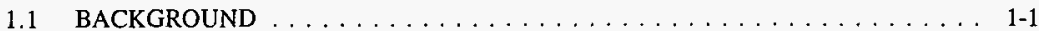

1.2 OBJECTIVES AND SCOPE OF ANALYSIS $\ldots \ldots \ldots \ldots \ldots \ldots$

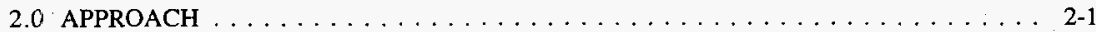

3.0 DESCRIPTION OF MISCELLANEOUS STREAMS AND

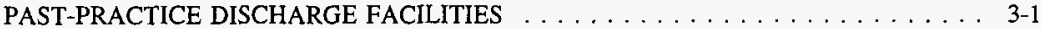

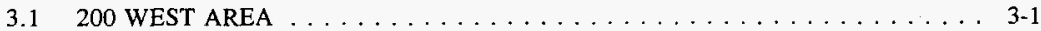

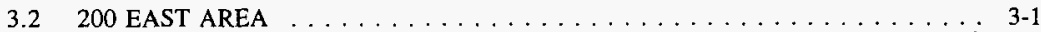

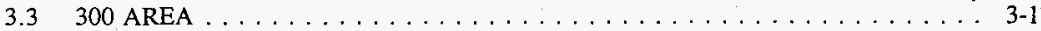

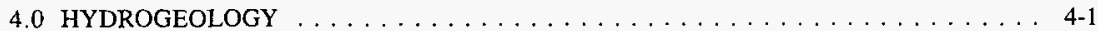

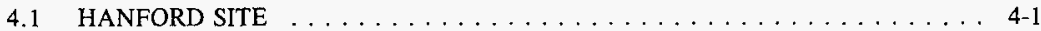

4.2 DISCHARGE SITES IN THE 200 WEST AREA $\ldots \ldots \ldots \ldots \ldots \ldots \ldots \ldots$

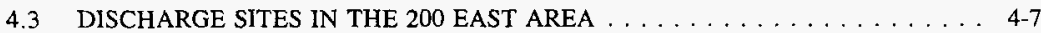

4.4 DISCHARGE SITES IN THE 300 AREA $\ldots \ldots \ldots \ldots \ldots \ldots \ldots \ldots \ldots$

5.0 NUMERICAL MODEL INPUT PARAMETERS $\ldots \ldots \ldots \ldots \ldots \ldots \ldots \ldots \ldots \ldots$

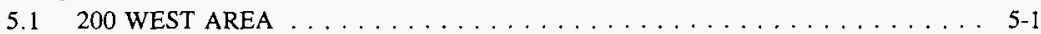

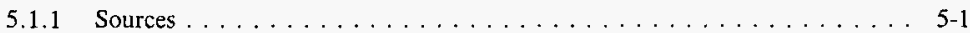

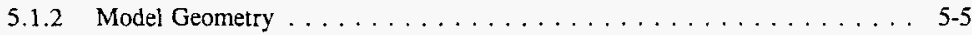

5.1 .3 Hydraulic Properties . . . . . . . . . . . . . . . . . 5-7

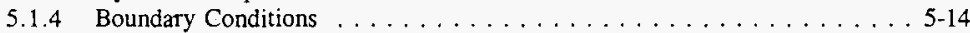

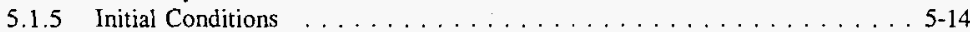

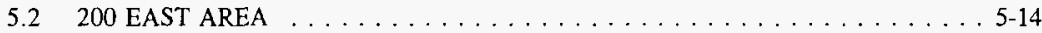

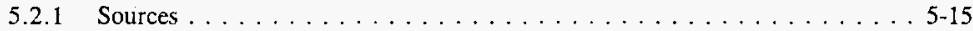

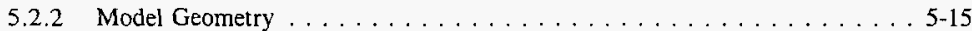

5.2 .3 Hydraulic Properties . . . . . . . . . . . . . . . . . 5-20

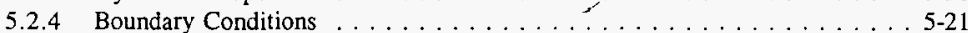

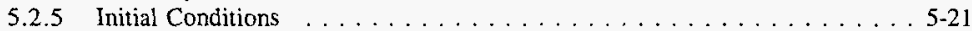

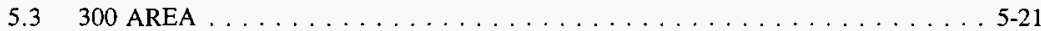

5.3 .1 Sources . . . . . . . . . . . . . . . . . . . . . . . $5-22$

5.3 .2 Model Geometry . . . . . . . . . . . . . . . . . . . . . 5-22

5.3 .3 Hydraulic Properties . . . . . . . . . . . . . . . . . . . 5-22

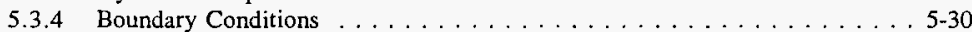

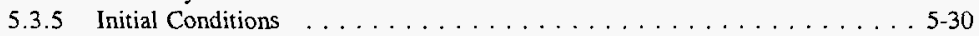

6.0 MOISTURE PROFILE RESULTS $\ldots \ldots \ldots \ldots \ldots \ldots \ldots \ldots \ldots \ldots \ldots \ldots$

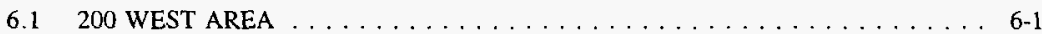

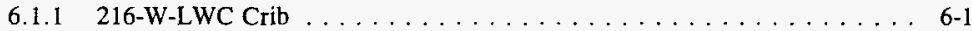

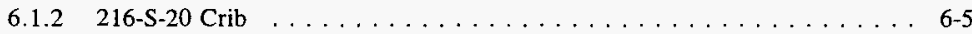

6.1 .3 Miscellaneous stream . . . . . . . . . . . . . . . 6-5

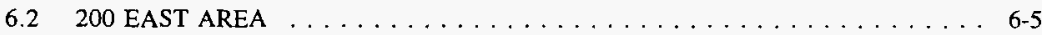

$6.2 .1 \quad 216-A-5$ Crib . . . . . . . . . . . . . . . . . . . $6-5$

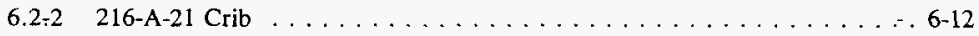


WHC-SD-LEF-ER-001, Rev. 0

CONTENTS (Continued)

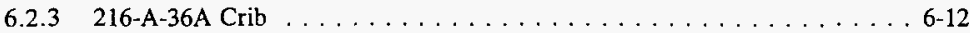

6.2 .4 Miscellaneous Stream . . . . . . . . . . . . . . 6-12

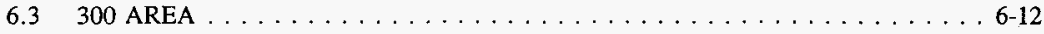

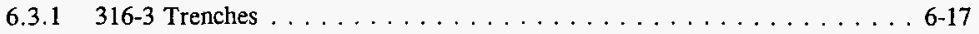

6.3 .2 Miscellaneous Stream . . . . . . . . . . . . . . 6-17

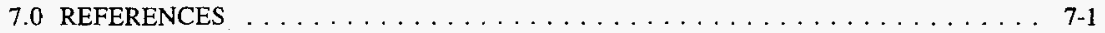

\section{APPENDIX:}

A 300 AREA HYDRAULIC DATA

A-1

\section{FIGURES:}

1-1. General Location of the Areas Analyzed . . . . . . . . . . . . . . . . . 1-3

3-1. Locations of Discharge Sites Analyzed for the 200 West Area . . . . . . . . . . . . . 3-2

3-2. Facilities and Stream Discharge Sites Near the $231-Z$ Building . . . . . . . . . . . 3-3

3-3. Facilities and Stream Discharge Sites Near the $\mathrm{Z}$ Plant . . . . . . . . . . . 3-4

3-4. Facilities and Stream Discharge Sites Near the 200 West Maintenance Area . . . . . . . 3-5

3-5. Facilities and Stream Discharge Sites East of the 241-S Tank Farm and $241-$ SX Tank Farm . . . . . . . . . . . . . . . . . . . .

3-6. Facilities and Stream Discharge Sites Near the 222-S Laboratory . . . . . . . . . . . . 3-7

3-7. Locations of Discharge Sites Analyzed for the 200 East Area . . . . . . . . . . . . 3-8

3-8. Facilities and Stream Discharge Sites Near the B Plant . . . . . . . . . . . . . . . . 3-9

3-9. Facilities and Stream Discharge Sites Near the PUREX Plant . . . . . . . . . . . 3-10

3-10. Facilities and Stream Discharge Sites in the 300 Area . . . . . . . . . . . . 3-12

4-1. Generalized Stratigraphy of the Hanford Site . . . . . . . . . . . . . . . . . 4-2

4-2. Stratigraphic Relationships of Sediments Above Basalt at the Hanford Site . . . . . . . 4-3

4-3. Representative Vadose Zone Stratigraphy of the 200 West Area . . . . . . . . . . . . 4-5

4-4. Representative Vadose Zone Stratigraphy of the 200 East Area . . . . . . . . . . . . 4-8

4-5. Representative Vadose Zone Stratigraphy of the 300 Area . . . . . . . . . . . . 4-10

5-1. Discharge Volumes for the 200 West Area Facilities . . . . . . . . . . . . . . 5-2

$5-2$. Discharge Rates for the 200 West Area Facilities . . . . . . . . . . . . . . . . 5-3

5-3. Flux Densities for the 200 West Area Facilities . . . . . . . . . . . . . . . . 5-4

5-4. Model Geometry for the 200 West Area Facilities . . . . . . . . . . . . . . . 5-6

5-5. Moisture Characteristic Plots for Hanford formation Gravel in the 200 West Area . . . . 5-8

5-6. Dry Bulk Density of Gravelly Sediments as a Function of Gravel Content. . . . . . . . . 5-9

5-7. Moisture Characteristic Plots for Hanford Formation Sand in the 200 West Area . . . . . 5-11

5-8. Moisture Characteristic Plots for the Plio-Pleistocene Unit in the 200 West Area . . . . . 5-12

5-9. Moisture Characteristic Plots for the Ringold Formation Unit E in the 200 West Area . . 5-13

5-10. Discharge Volumes for the 200 East Area Facilities . . . . . . . . . . . . . 5-16

5-11. Discharge Rates for the 200 East Area Facilities . . . . . . . . . . . . . . 5-17

5-12. Flux Densities for the 200 East Area Facilities . . . . . . . . . . . . . . . 5-18

5-13. Model Geometry for the 200 East Area Facilities . . . . . . . . . . . . . . . . 5-19

5-14. Discharge Volumes for the 300 Area Facility . . . . . . . . . . . . . . . . 5-23 
CONTENTS (Continued)

\section{FIGURES (cont):}

5-15. Discharge Rates for the 300 Area Facility . . . . . . . . . . . . . . . 5-24

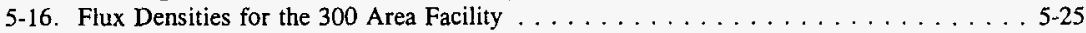

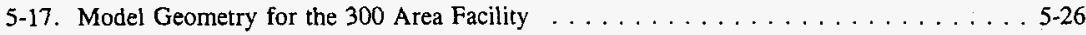

5-18. Moisture Characteristic Plots for Sand in the 300 Area . . . . . . . . . . . . 5-28

5-19. Moisture Characteristic Plots for Sand in the 300 Area . . . . . . . . . . . . . . 5-29

6-1. Pre-operations Moisture Profile for the 216-W-LWC Crib . . . . . . . . . . . 6-2

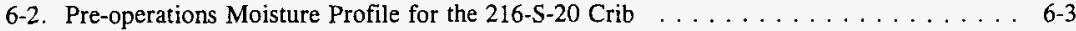

6-3. Post-operations Moisture Profile for the 216-W-LWC Crib . . . . . . . . . . $6-4$

$6-4$. Moisture Profile for the $216-\mathrm{S}-20 \mathrm{Crib} \ldots \ldots \ldots \ldots \ldots \ldots \ldots \ldots$. . . . . . . . .

6-5. Two-Dimensional Moisture Profile for a 20-Ft-Wide Miscellaneous Stream in the 200 West Area . . . . . . . . . . . . . . . . . . . . . 6 $6-7$

6-6. Axisymmetric Moisture Profile for a 20-Ft-Diameter Miscellaneous Stream

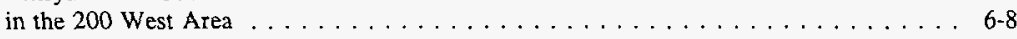

6-7. Axisymmetric Moisture Profile for a 4-Ft-Diameter Miscellaneous Stream in the 200 West Area . . . . . . . . . . . . . . . . . . . . . . . . $6-9$

6-8. Pre-operations Moisture Profile for the 200 East Area Model . . . . . . . . . . . . . . 6-10

6-9. Moisture Profile for the $216-\mathrm{A}-5$ Crib $\ldots \ldots \ldots \ldots \ldots \ldots \ldots \ldots \ldots \ldots$

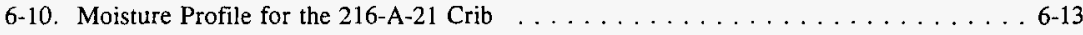

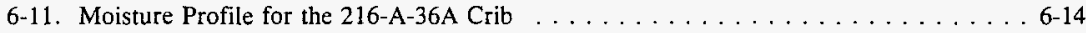

6-12. Two-Dimensional Moisture Profile for a 20-Ft-Wide Miscellaneous Stream

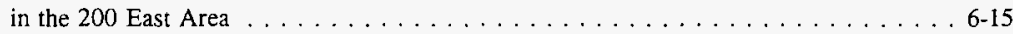

6-13. Pre-Operations Moisture Profile for the 300 Area Model . . . . . . . . . . . . . . 6-16

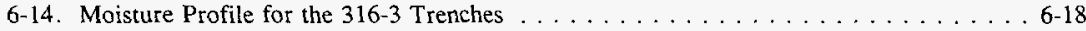

6-15. Moisture Profile for Miscellaneous Stream in the 300 Area . . . . . . . . . . . . . 6-19

\section{TABLES:}

3-1. Discharge Parameters for Past-Practice Facilities in the 200 West Area . . . . . . . . 3-11

3-2. Discharge Parameters for Past-Practice Facilities in the 200 East Area and the 300 Area . 3-13

5-1. Adjusted Hydraulic Properties Used as Input Values for the 200 West Area Sediments . . . 5-7

5-2. Comparison of Average Dry Bulk Densities with Gravel Contents . . . . . . . . . . 5-10

5-3. Hydraulic Properties Used as Input Values for the 200 East Area Sediments . . . . . . . 5-20

5-4. Soil Hydraulic Properties Used as Input Values for the 300 Area Sediments . . . . . . . 5-27

6-1. Lateral Spreading of Moisture for Various Miscellaneous Stream Configurations . . . . . 6-5 
WHC-SD-LEF-ER-001, Rev. 0

Intentionally left blank. 
WHC-SD-LEF-ER-001, Rev. 0

\subsection{INTRODUCTION}

This report provides a hydrogeologic analysis of the potential impacts of several, low-volume $(<.0032 \mathrm{~L} / \mathrm{s}[<0.05 \mathrm{gal} / \mathrm{min}])$ effluent discharges on vadose zone contamination that may have resulted from the operation of past-practice effluent disposal facilities (cribs, ditches, and ponds). The low-volume discharges considered here are included in a category broadly designated as "Miscellaneous Streams." This study was commissioned to evaluate compliance with the requirements and provisions of the Washington State Department of Ecology (Ecology) Consent Order No. DE91NM-177 (Consent Order) (Ecology and the U.S. Department of Energy [DOE] 1991), and is provided as technical support to the Miscellaneous Streams Best Management Practices (BMP) Report (DOE-RL 1996).

\subsection{BACKGROUND}

In December 1991, the DOE-Richland Operations Office (DOE-RL) and Ecology established regulatory milestones in the Consent Order for three categories of liquid effluent streams discharged to the soil column at the Hanford Site: (1) Phase I Streams; (2) Phase II Streams; and (3) Miscellaneous Streams (DOE-RL 1994). Miscellaneous streams are defined as those liquid effluents identified in the Consent Order (Ecology and DOE 1991) that are discharged to the soil column, exclusive of Phase I and Phase II streams. Brief descriptions, estimated rates of discharge, and categorization of miscellaneous streams are provided in Inventory of Miscellaneous Streams (DOE-RL 1995).

Category "d" streams are defined as miscellaneous streams discharging to the soil column

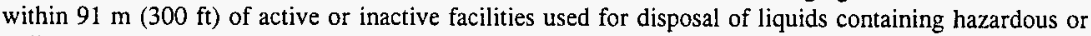
radioactive materials (DOE:RL 1995). The " $d$ " streams are discharged at 47 sites and consist either of stormwater or steam condensate (potable water). The $91-\mathrm{m}(300-\mathrm{ft})$ criterion was selected as a screening parameter for the siting of new effluent disposal facilities in the vicinity of existing facilities. This criterion was considered a conservative "estimate" of the maximum extent of lateral spreading of effluent from the area of infiltration at the surface to the groundwater. The estimate is based on limited observations of soil moisture during borehole drilling adjacent to existing facilities (DOE-RL 1994; D. K. Tyler, personal communication). Moisture from new discharges was assumed to have the potential to intersect and remobilize contaminants left in the vadose zone by preexisting facility operations.

Preferred alternatives have been proposed to minimize the potential for the "d" streams to intersect zones of contamination, including; eliminating the stream, redirecting the " $\mathrm{d}$ " stream to another location, installation of additional equipment, or taking no action. Additional costs would result from implementing any of the preferred alternatives except "no action." Accurate evaluation of the probable lateral extent of moisture spreading beneath the facilities and " $\mathrm{d}$ " streams, through hydrogeologic modeling, will aid in selecting preferred alternatives. The evaluation is based on the nurnerical modeling effort described in this report. 


\subsection{OBJECTIVES AND SCOPE OF ANALYSIS}

This analysis encompasses specific areas within the 200 Areas and 300 Area at the Hanford Site (Figure 1-1). The primary objective of the analysis was to evaluate the probable lateral extent of subsurface moisture migration beneath past-practice facilities located in the vicinity of " $\mathrm{d}$ " stream discharges. The evaluation was accomplished by numerically simulating the movement of moisture in the vadose zone. The results of the simulation aid in selecting the appropriate action to be taken to manage the streams. This objective is accomplished by the following:

- Defining the stratigraphy and hydraulic characteristics of the vadose zone in the vicinity of " $d$ " streams that are near past-practice facilities

- Selecting a representative set of stratigraphic and hydraulic properties for each general area of interest (200 West, 200 East, and 300 areas) and deriving appropriate model configurations

- Simulating groundwater movement for each area of interest to predict the extent of lateral spreading of moisture and intersections of areas of wetting in the vadose zone resulting from past-practice facilities and " $d$ " streams operations

- Illustrating the results of each model as two-dimensional patterns of moisture migration from past-practice facility discharges and "d" streams.

This analysis accounts only for the distribution of moisture in the vadose zone beneath past-practice facilities and " $d$ " streams (streams) that result from natural recharge and facility and stream operations. The analysis does not predict the distribution of contaminants that may have been contained in the waste streams directed to the facilities. 
WHC-SD-LEF-ER-001, Rev. 0

Figure 1-1. General Location of the Areas Analyzed.

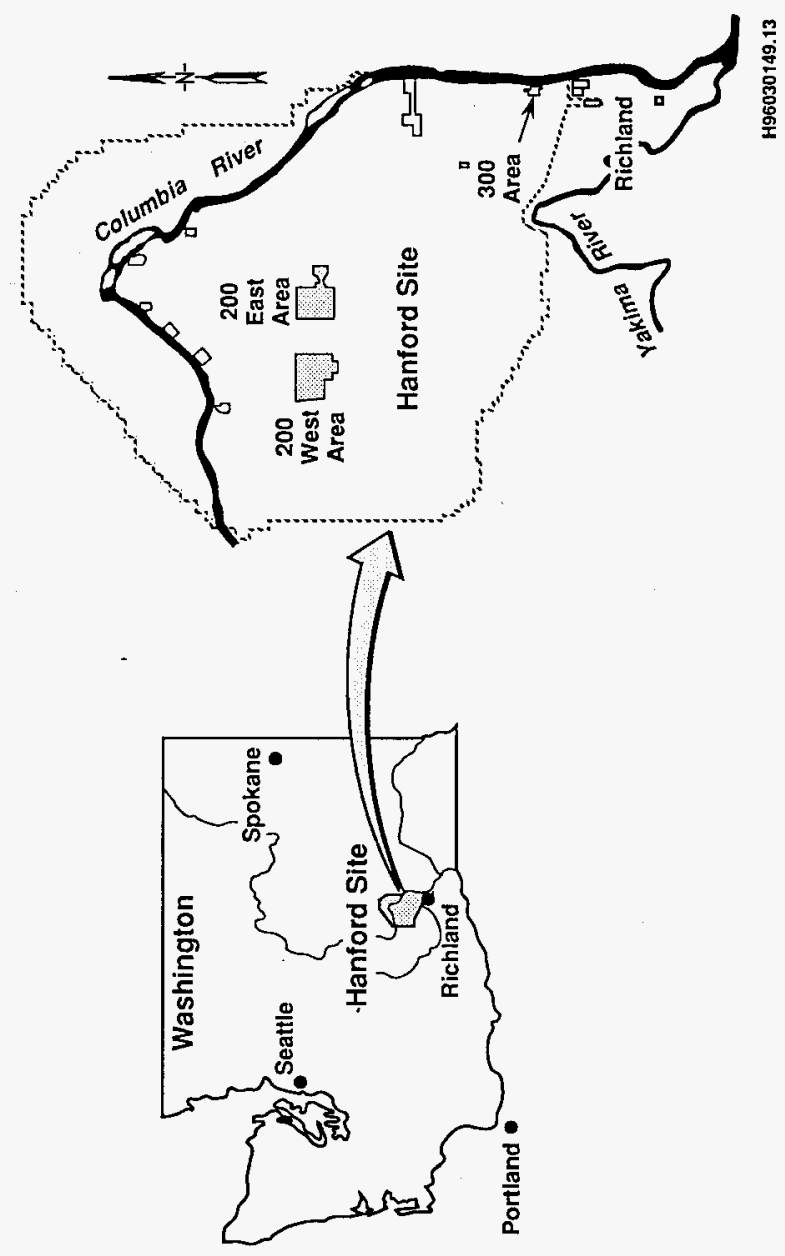


WHC-SD-LEF-ER-001, Rev. 0

Intentionally left blank. 
WHC-SD-LEF-ER-001, Rev. 0

\subsection{APPROACH}

Separate stratigraphic representations were developed to depict the hydrology of the 200 West, 200 East, and 300 areas. Geologic logs of wells nearest the areas of interest were reviewed. Based on inspection of these well logs, representative stratigraphic cross sections were constructed. A single columnar section was selected for each area to represent the major hydrogeologic features of the vadose zone for the locations of interest. The major lithologic units of these sections were then depicted by the mathematical model as zones with distinct hydraulic properties.

Input parameters for the PORFLOW mathematical model (Runchal et al. 1992) were selected from existing information published for lithologic units intersected by boreholes in each area. The best available information was identified based on (1) comparison of the catalogued site-specific values with published values for similar sediments elsewhere and (2) correctness of the curve fitting for soil moisture characteristics, where appropriate. As discussed in Section 5.1.3, adjustments were made in instances for which inspection of published soil hydraulic property data (Khaleel and Freeman 1995) revealed that some values had been incorrectly calculated from the raw data.

Simplified two-dimensional-profile models were developed to facilitate the analysis. The two-dimensional nature of the models enhanced the apparent degree of lateral spreading relative to that which would be indicated by three-dimensional models. The past-practice discharges in the 200 East Area were organized into three groups to reduce the amount of modeling required. Similarly, the past-practice discharges in the 200 West Area were organized into two groups. A single past-practice discharge was of interest in the 300 Area. Each group was defined by examining (1) the total volume of discharge, (2) the rate of discharge, and (3) the rate of discharge per unit horizontal area (i.e., the vertical flux density). The facility groupings for each area are discussed in Chapter 5.0. 
WHC-SD-LEF-ER-001, Rev. 0

Intentionally left blank. 


\subsection{DESCRIPTION OF MISCELLANEOUS STREAMS AND PAST-PRACTICE DISCHARGE FACILITIES}

Twenty-one past-practice facilities were identified that are within $(91 \mathrm{~m})(300 \mathrm{ft})$ of a stream discharge point(s); nine facilities in the 200 East Area, 11 facilities in the 200 West Area, and one facility in the 300 Area. Forty-seven streams are within $91 \mathrm{~m}(300 \mathrm{ft})$ of at least one of these facilities. Figures 3-1 through 3-9 show the locations of the past-practice facilities and streams in the 200 Areas. Stream numbers shown in these figures correspond to those listed in DOE-RL (1995). For purpose of reference, the streams and facilities were considered in terms of five locations within the 200 West Area and two locations within the 200 East Area.

All streams considered here were determined by field measurements to have an average constant discharge rate of $\sim 0.0032 \mathrm{~L} / \mathrm{s}(-0.05 \mathrm{gal} / \mathrm{min})$. Discharge parameters for the 21 pastpractice facilities are described in the following sections.

\subsection{WEST AREA}

The 11 past-practice facilities and the 29 streams in the 200 West Area are in five locations (Figure 3-1); near the 231-Z Building, Plutonium Finishing Plant (Z Plant), 200 West maintenance area and the 222-S Laboratory, and along the steam line east of 241-S and 241-SX Tank Farms.

Figures 3-2 through 3-6 show details of each location. Discharge parameters for the facilities are listed in Table 3-1 by location, as defined above. The surface areas of facilities shown in the figures may not agree with those shown in the table because the figures generally portray the fenced areas, while the dimensions in the table refer to infiltration surface areas.

\subsection{EAST AREA}

Discharges of streams near past-practice facilities in the 200 East Area occur near B Plant and the Plutonium-Uranium Extraction (PUREX) Plant. These locations are shown in Figure 3-7. Details of the locations are shown in Figures 3-8 and 3-9. Discharge parameters for the 200 East Area facilities are listed in Table 3-2. The surface areas of facilities shown in the figures may not agree with those shown in the table because the figures generally portray the fenced areas while the dimensions in the table refer to infiltration surface areas.

\section{$3.3 \quad 300$ AREA}

One past-practice facility is of interest in the 300 Area, the $316-3$ Trenches (Figure 3-10). Seven streams are located near this facility. The facility consisted of two parallel trenches, each

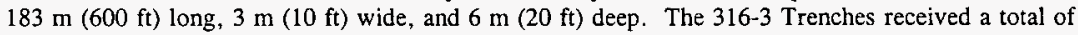
$1.0 \times 10^{9} \mathrm{~L}$ of effluent. In 1963 , contaminated soil was removed from the facility's trenches and taken to the $300 \mathrm{~N}$ Burial Ground. Discharge parameters for the 316-3 Trenches are given in Table 3-2. 
WHC-SD-LEF-ER-001, Rev. 0

Figure 3-1. Locations of Discharge Sites Analyzed for the 200 West Area.

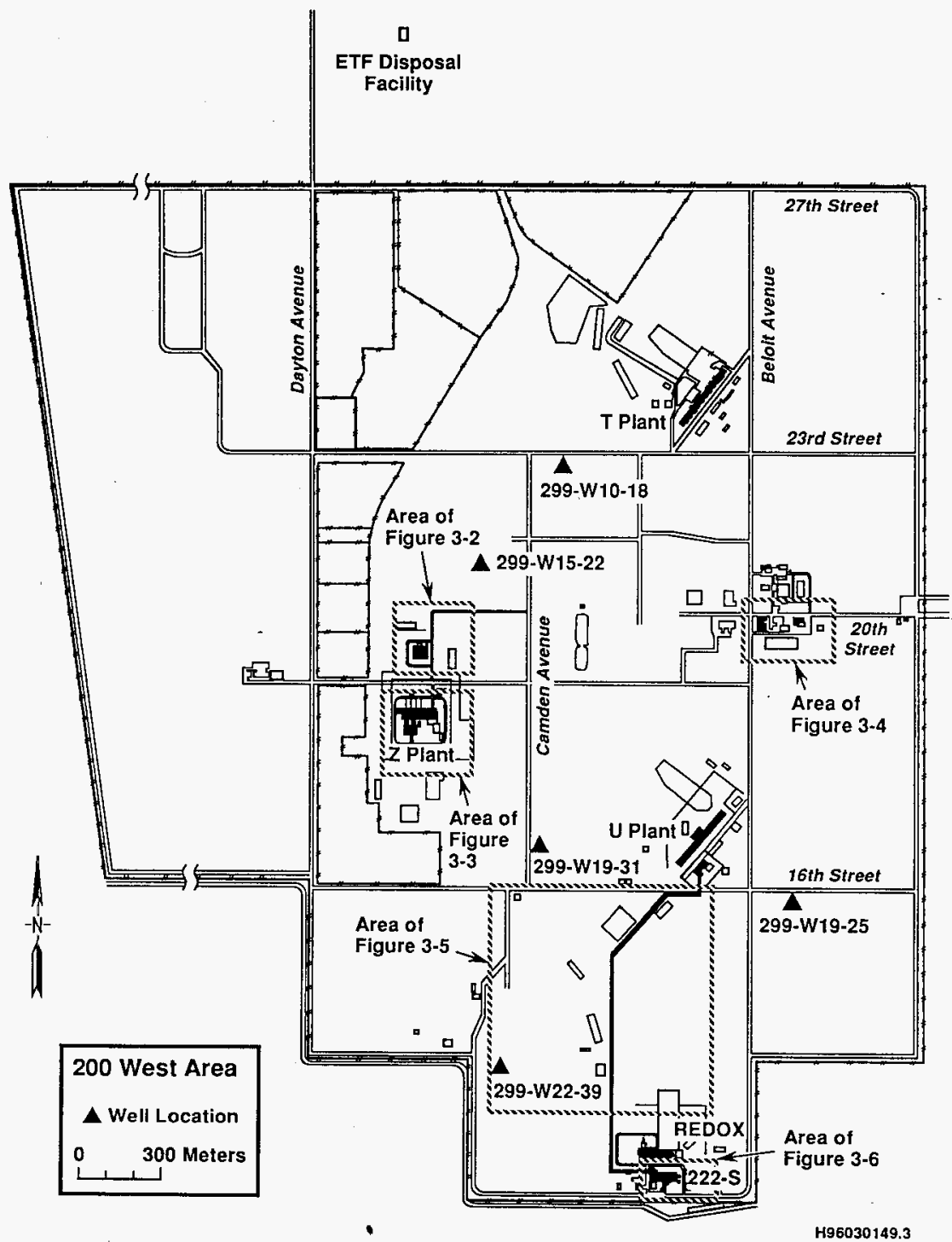


Figure 3-2. Facilities and Stream Discharge Sites Near the 231-Z Building.

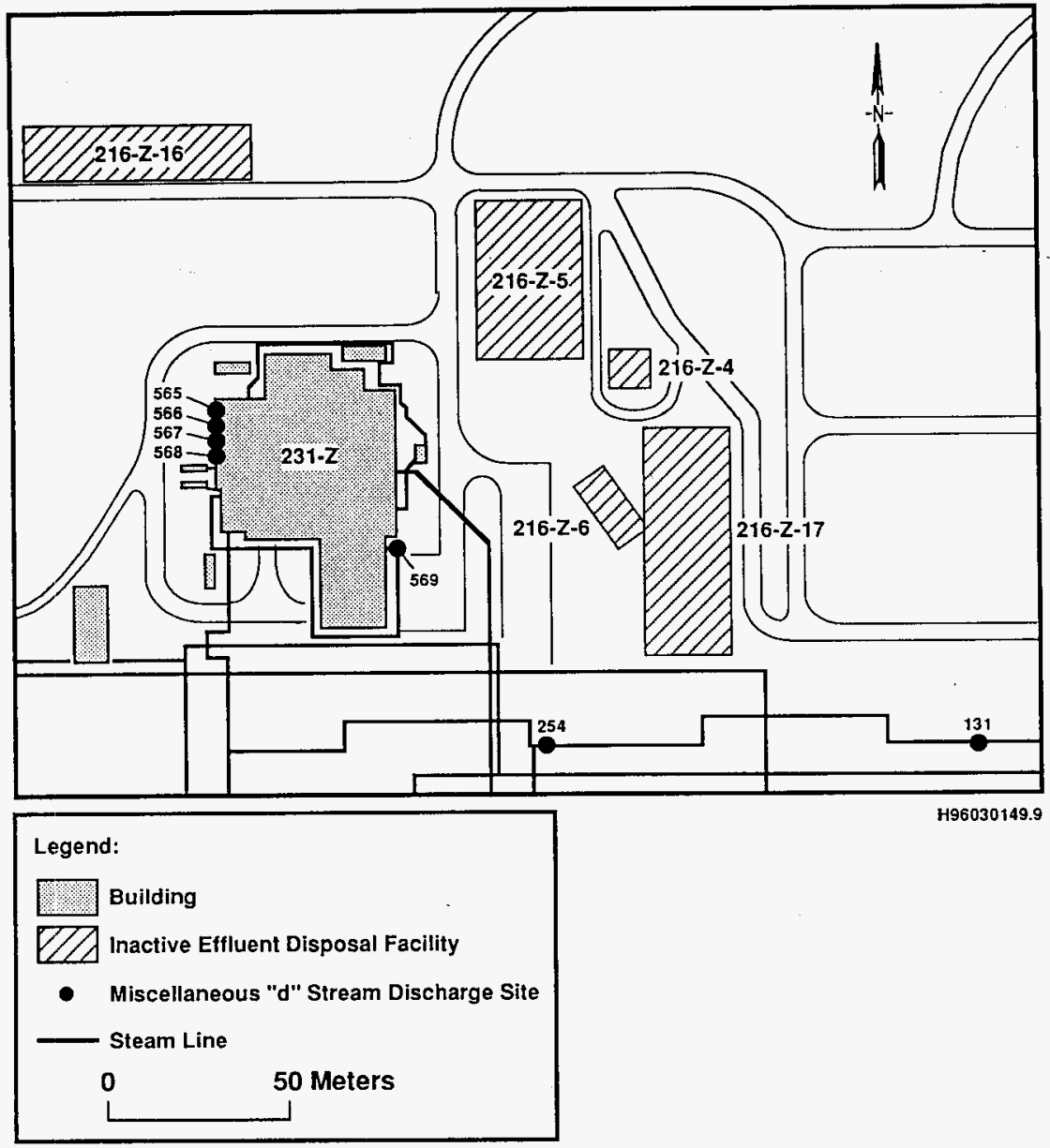


WHC-SD-LEF-ER-001, Rev. 0

Figure 3-3. Facilities and Stream Discharge Sites Near the Z Plant.

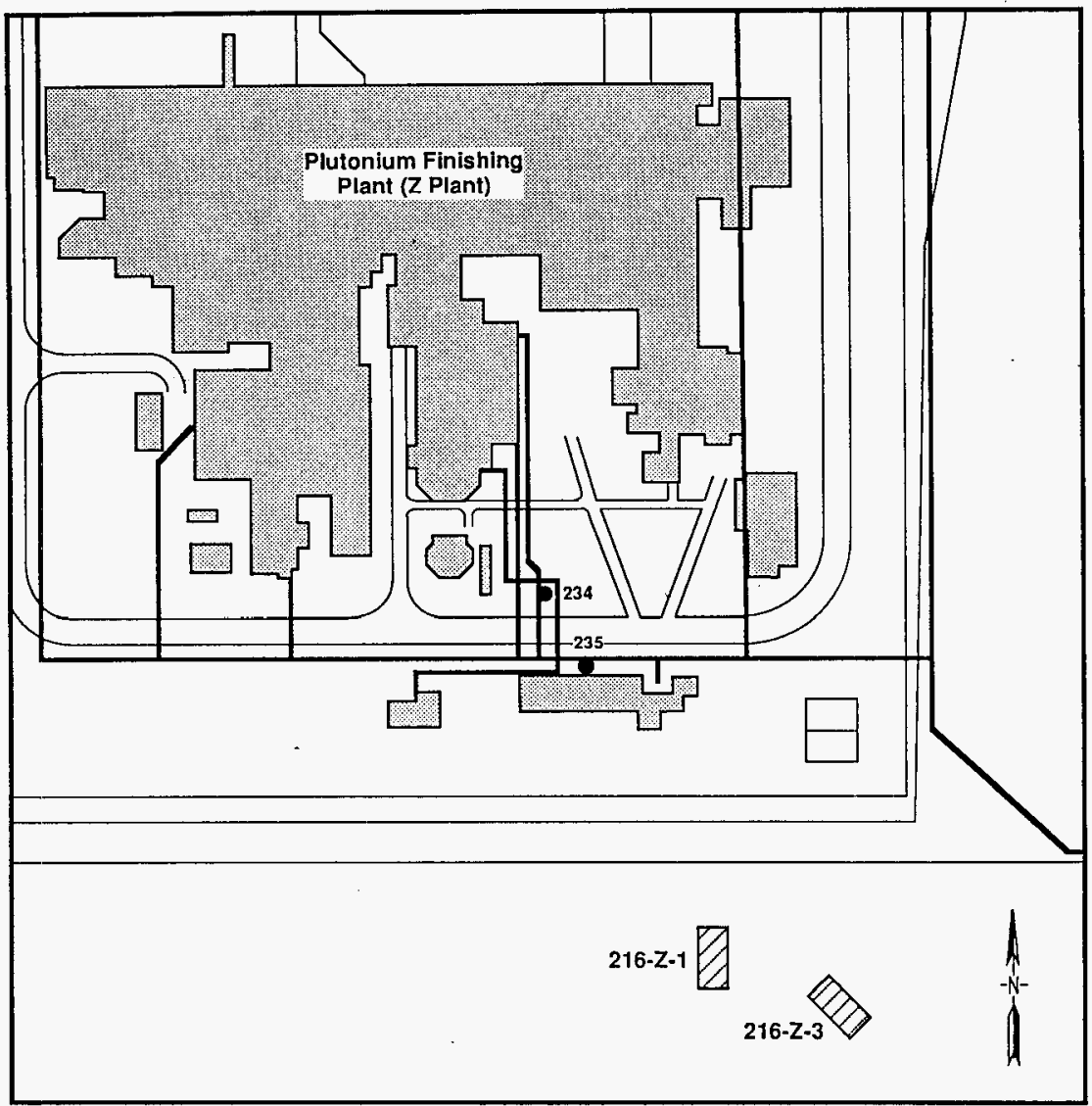

Legend:

H96030149.6

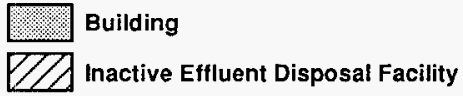

- Miscellaneous "d" Stream Discharge Site

Steam Line

0

100 Meters 1 
WHC-SD-LEF-ER-001, Rev. 0

Figure 3-4. Facilities and Stream Discharge Sites Near the 200 West Maintenance Area.

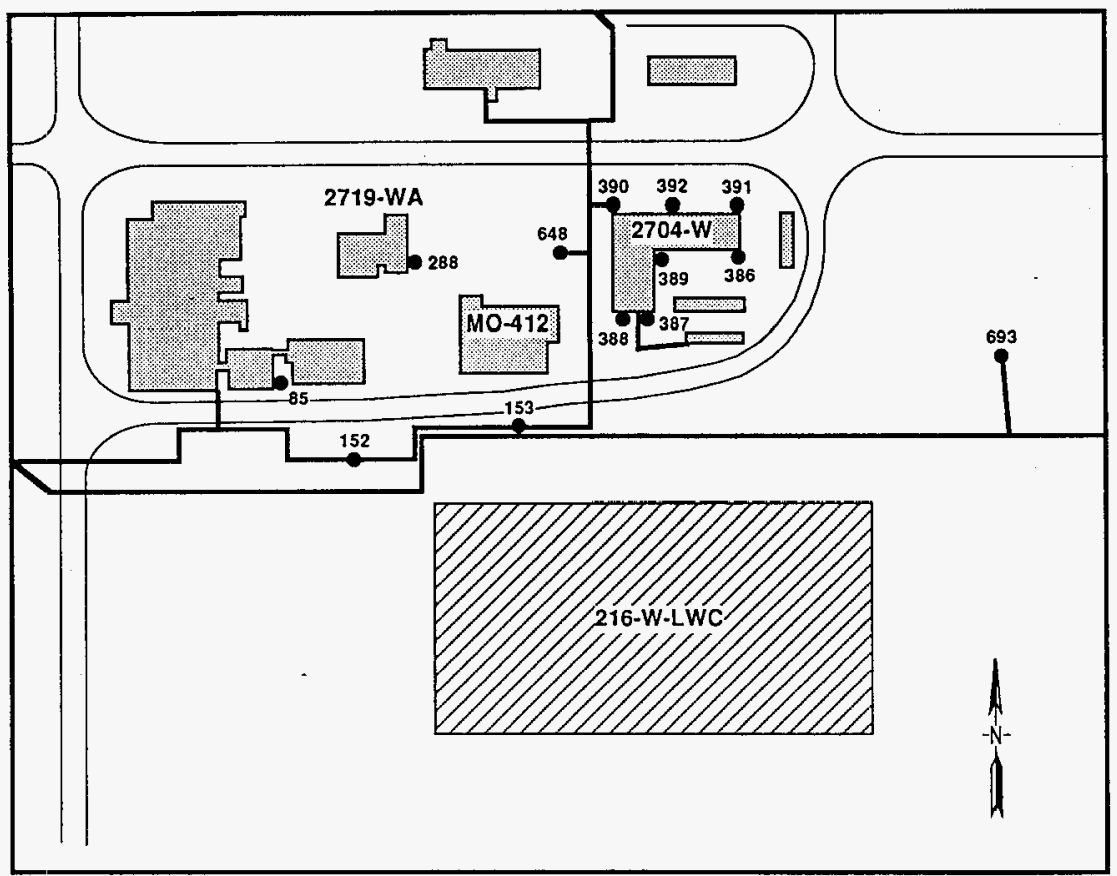

Legend:
Building
Inactive Effluent Disposal Facility

H96030149.5

- Miscellaneous " $d$ " Stream Discharge Site

- Steam Line

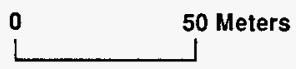


Figure 3-5. Facilities and Stream Discharge Sites East of the 241-S Tank Farm and 241-SX Tank Farm.

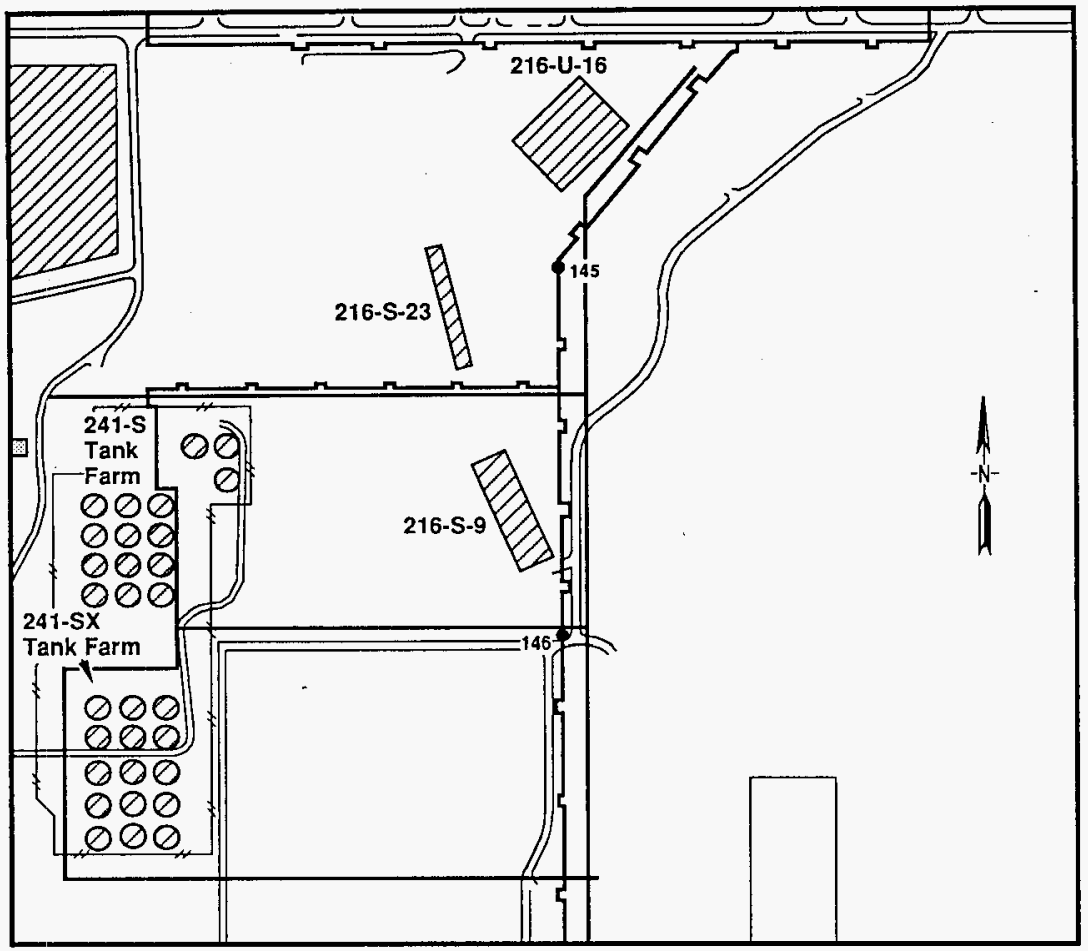

H96030149.7

Legend:

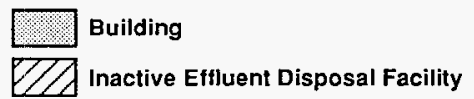

- Miscelianeous "d" Stream Discharge Site Steam Line

0 250 Meters 
Figure 3-6. Facilities and Stream Discharge Sites Near the 222-S Laboratory.
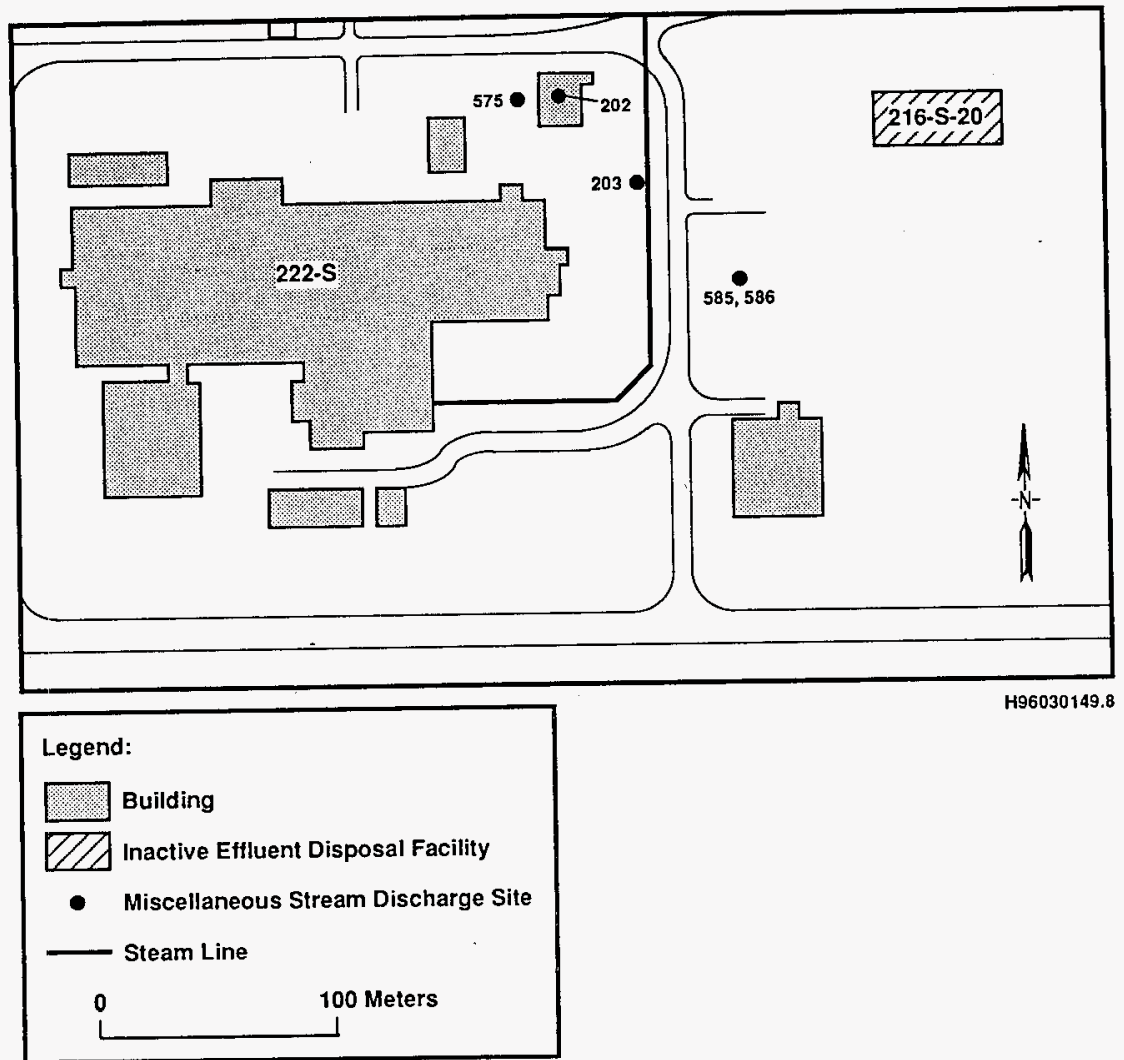
WHC-SD-LEF-ER-001, Rev. 0

Figure 3-7. Locations of Discharge Sites Analyzed for the 200 East Area.

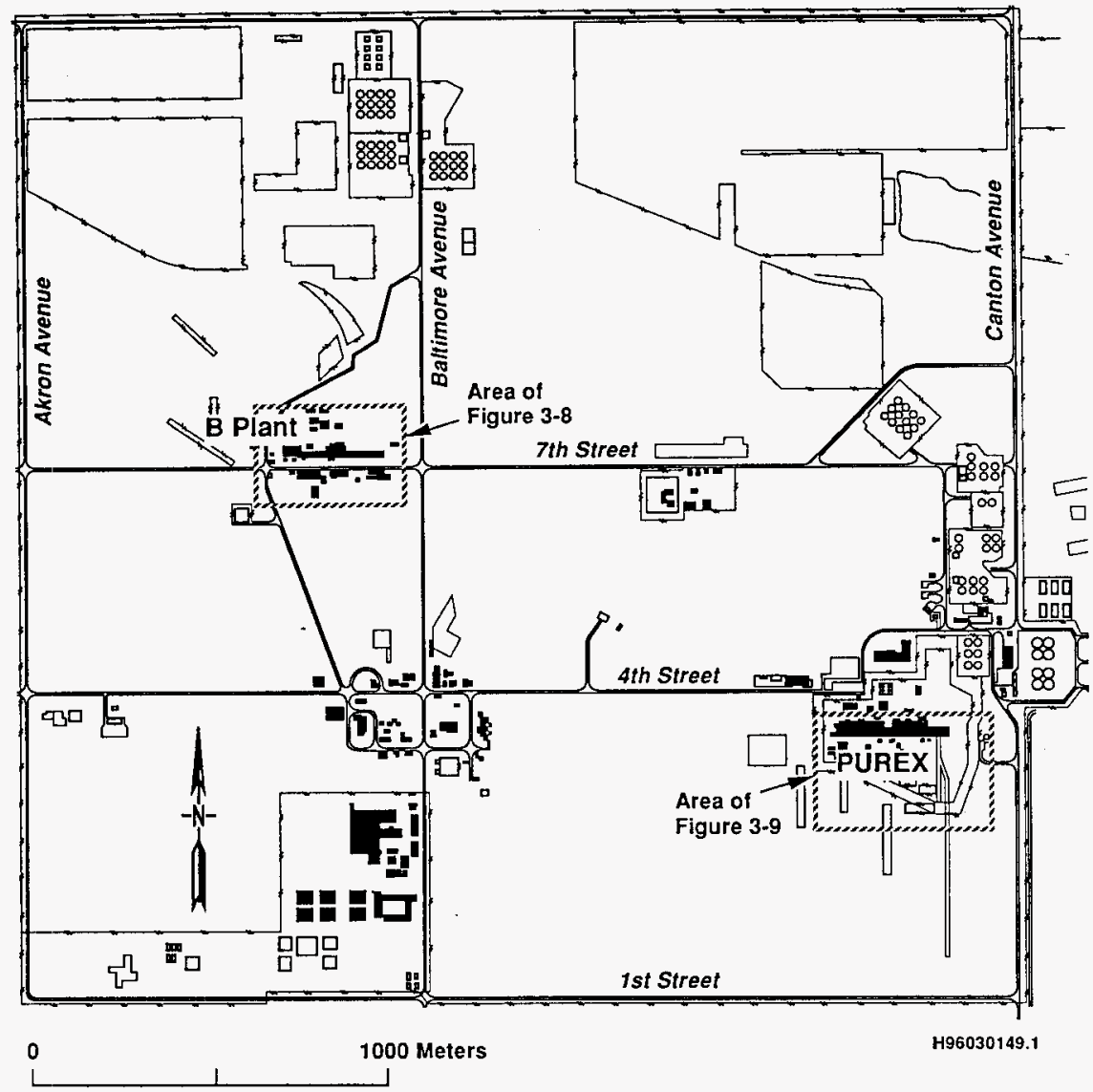


WHC-SD-LEF-ER-001, Rev. 0

Figure 3-8. Facilities and Stream Discharge Sites Near the B Plant.

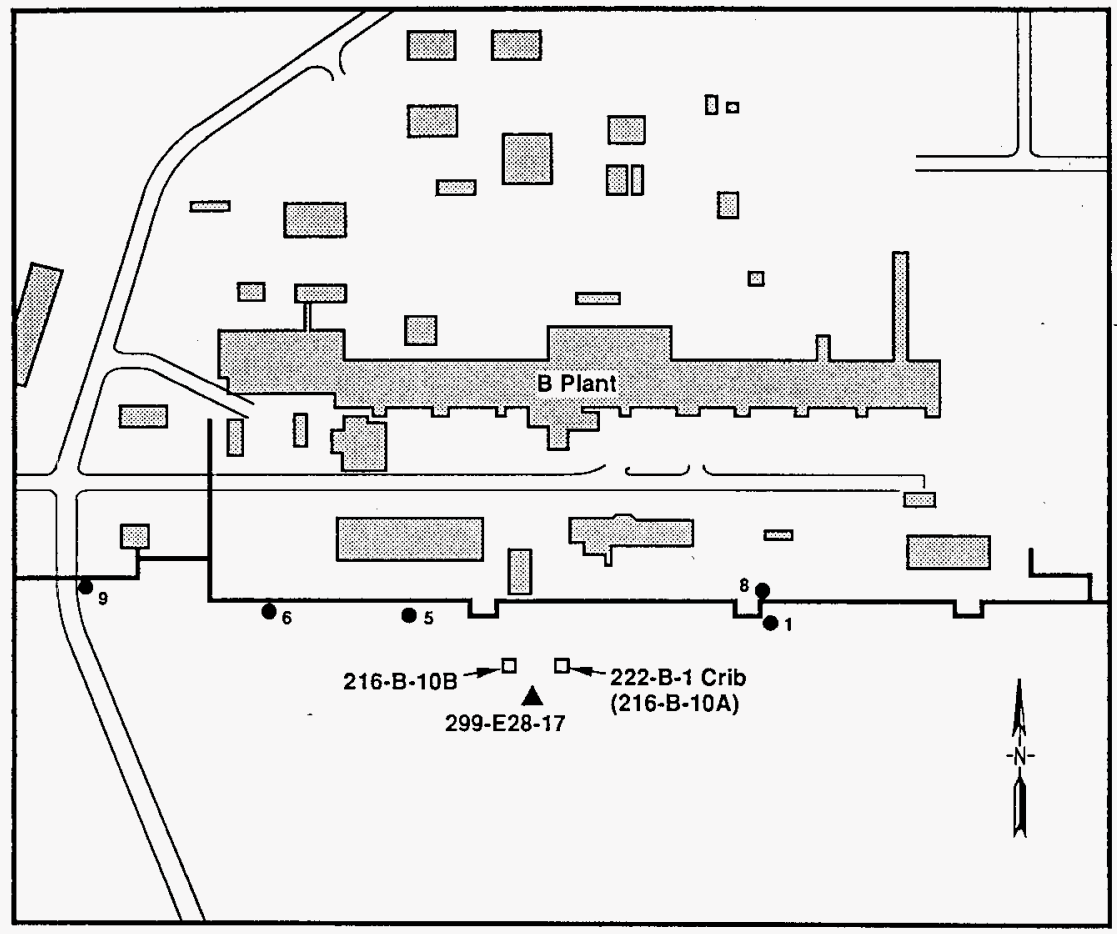

Legend:

Building
$\square$ Inactive Effluent Disposal Facility

- Miscellaneous Stream Discharge Site

A Well Location

Steam Line

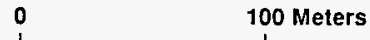

H96030149.4 
WHC-SD-LEF-ER-001, Rev. 0

Figure 3-9. Facilities and Stream Discharge Sites Near the PUREX Plant.

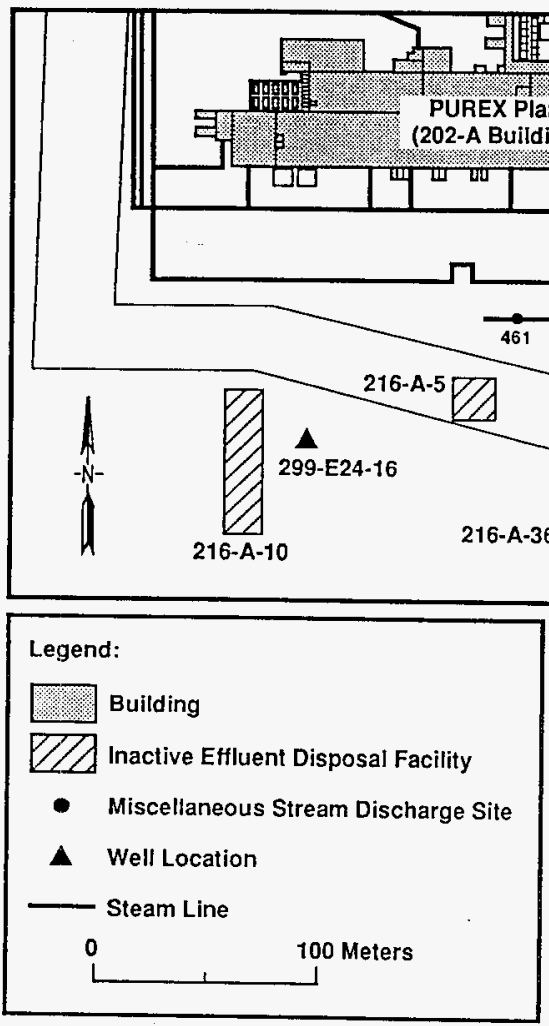


Table 3-1. Discharge Parameters for Past-Practice Facilities in the 200 West Area.

\begin{tabular}{|c|c|c|c|c|c|c|}
\hline Facility & $\begin{array}{c}\text { Plan Vjew } \\
\text { Dimensions } \\
\text { (m) }\end{array}$ & $\begin{array}{c}\text { Discharge } \\
\text { Area } \\
\left(\mathrm{m}^{2}\right)\end{array}$ & $\begin{array}{l}\text { Years of } \\
\text { Operation }\end{array}$ & $\begin{array}{l}\text { Total } \\
\text { Effluent } \\
\text { Volume } \\
\text { (L) }\end{array}$ & $\begin{array}{c}\text { Average } \\
\text { Discharge } \\
\left(\mathrm{m}^{3} / \mathrm{yr}\right)\end{array}$ & $\begin{array}{c}\text { Flux Density } \\
\left(\mathrm{m}^{3} / \mathrm{yr} / \mathrm{m}^{2}\right)\end{array}$ \\
\hline \multicolumn{7}{|c|}{ NEAR 231-Z BUILDING } \\
\hline $216-Z-4$ & $3.05 \times 3.05$ & 9.3 & $\begin{array}{c}1 \\
(1945)\end{array}$ & $1.1 \times 10^{4}$ & $1.10 \times 10^{1}$ & 1.16 \\
\hline $216-Z-5$ & $3.65 \times 3.65^{\prime}$ & 26.7 & $\begin{array}{c}3 \\
(1945-1947)\end{array}$ & $3.1 \times 10^{7}$ & $1.03 \times 10^{4}$ & 387.27 \\
\hline $216-Z-6$ & $15.85 \times 2.59$ & 41.1 & $\begin{array}{c}1 \\
(1945)\end{array}$ & $9.8 \times 10^{4}$ & $9.80 \times 10^{2}$ & 2.84 \\
\hline $216-Z-16$ & $54.86 \times 3.05$ & 167.3 & $\begin{array}{c}10 \\
(1968-1977)\end{array}$ & $1.02 \times 10^{8}$ & $1.02 \times 10^{4}$ & 61.00 \\
\hline $216-Z \cdot 17$ & $60.96 \times 3.05$ & 185.9 & $\stackrel{2}{(1967-1968)}^{2}$ & $3.68 \times 10^{7}$ & $1.84 \times 10^{4}$ & 99.03 \\
\hline \multicolumn{7}{|c|}{ NEAR Z PLANT } \\
\hline $\begin{array}{l}216-Z-1 \\
216-Z-3\end{array}$ & $\begin{array}{r}9.14 \times 9.14 \\
21.34 \times 1.52\end{array}$ & $116.0^{h}$ & $\begin{array}{c}21 \\
(1949-1969)\end{array}$ & $1.83 \times 10^{8}$ & $8.71 \times 10^{3}$ & 75.12 \\
\hline \multicolumn{7}{|c|}{ NEAR 200 WEST MAINTENANCE AREA } \\
\hline 216-W-LWC & $45.67 \times 40.50^{\circ}$ & $3,699.5^{a}$ & $\begin{array}{c}13 \\
(1981-1993) \\
\end{array}$ & $1.04 \times 10^{9}$ & $8.01 \times 10^{4}$ & 21.64 \\
\hline \multicolumn{7}{|c|}{ EAST OF 241-S AND 241-SX TANK FARMS } \\
\hline $216-S-9$ & $91.44 \times 9.14$ & 835.8 & $\begin{array}{c}5 \\
(1965-1969)\end{array}$ & $5.03 \times 10^{7}$ & $1.01 \times 10^{4}$ & 12.04 \\
\hline $216-S-23$ & $109.73 \times 3.05$ & 334.7 & $\begin{array}{c}4 \\
1969-1972)\end{array}$ & $3.41 \times 10^{7}$ & $8.52 \times 10^{3}$ & 25.45 \\
\hline $216-\mathrm{U}-13$ & $79.86 \times 58.22$ & $4,649.4$ & $\begin{array}{c}2 \\
(1984-1985) \\
\end{array}$ & $4.09 \times 10^{8}$ & $2.05 \times 10^{5}$ & 44.02 \\
\hline \multicolumn{7}{|c|}{ NEAR 222-S LABORATORY } \\
\hline $216 \cdot \$-20$ & $27.43 \times 12.19$ & 334.4 & $\begin{array}{c}18 \\
(1952-1969)\end{array}$ & $1.35 \times 10^{6}$ & 76.70 & 0.23 \\
\hline
\end{tabular}

a Two structures, each with these dimensions; area is total for both structures.

b Total area for both structures. 
Figure 3-10. Facilities and Stream Discharge Sites in the 300 Area.

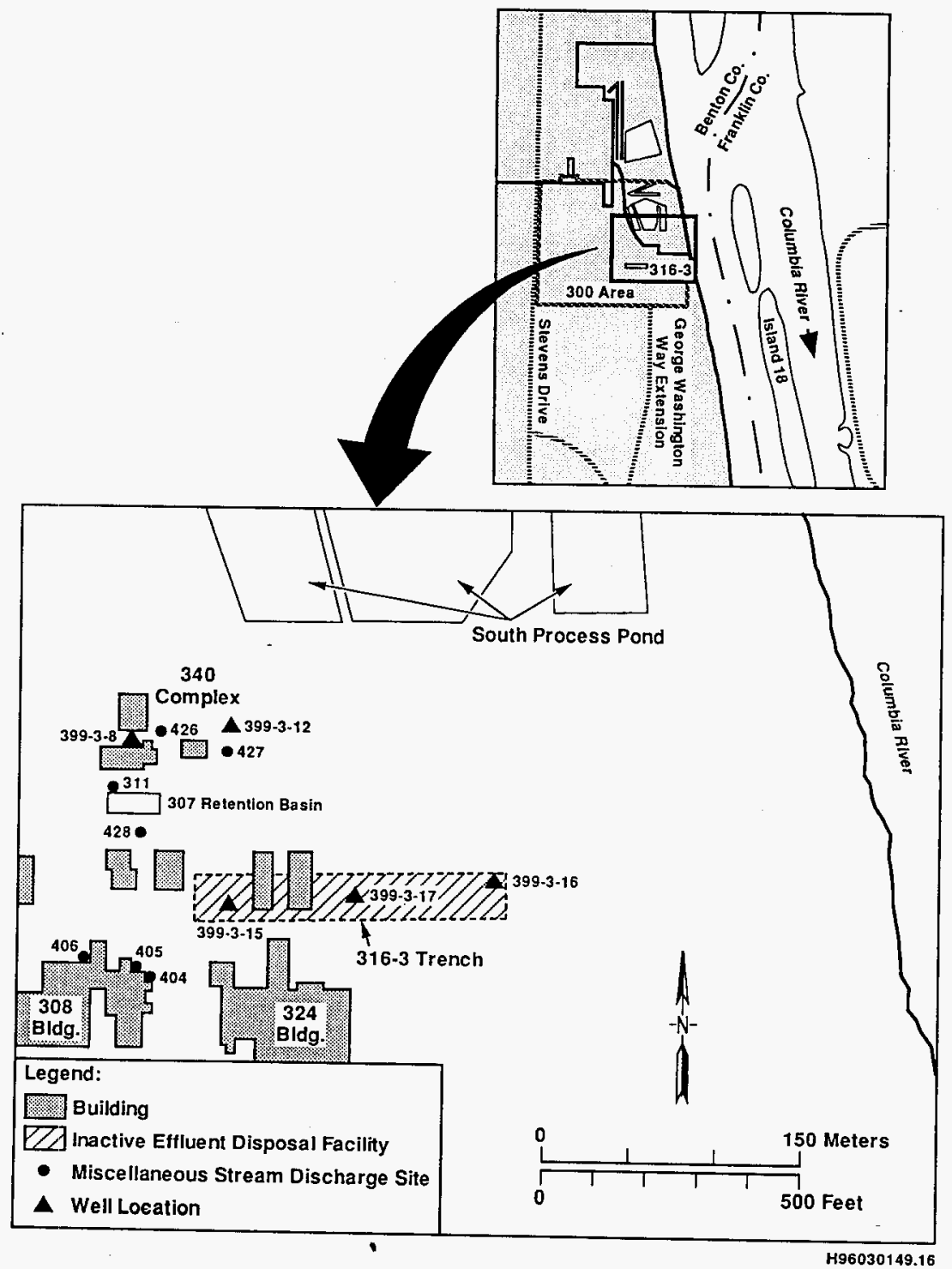


WHC-SD-LEF-ER-001, Rev. 0

Table 3-2. Discharge Parameters for Past-Practice Facilities in the 200 East Area and the 300 Area.

\begin{tabular}{|c|c|c|c|c|c|c|}
\hline Facility & $\begin{array}{c}\text { Plan View } \\
\text { Dimensions } \\
\text { (m) }\end{array}$ & $\begin{array}{c}\text { Discharge } \\
\text { Area } \\
\left(\mathrm{m}^{2}\right)\end{array}$ & $\begin{array}{l}\text { Years of } \\
\text { Operation }\end{array}$ & $\begin{array}{l}\text { Toral Effluent } \\
\text { Volume (L) }\end{array}$ & $\begin{array}{c}\text { Average } \\
\text { Discharge } \\
\left(\mathrm{m}^{3} / \mathrm{yr}\right)\end{array}$ & $\begin{array}{c}\text { Flux density } \\
\left(\mathrm{m}^{3} / \mathrm{yr} / \mathrm{m}^{2}\right)\end{array}$ \\
\hline \multicolumn{7}{|c|}{ NEAR B PLANT - 200 EAST AREA } \\
\hline $216-B-10 A, B$ & $4.26 \times 4.26^{\circ}$ & 36.2 & $\begin{array}{c}4 \\
(1949-1952)\end{array}$ & $1.0 \times 10^{9}$ & $2.50 \times 10^{4}$ & 691.05 \\
\hline \multicolumn{7}{|c|}{ NEAR PUREX PLANT - 200 EAST AREA } \\
\hline 216-A-2 & $6.10 \times 6.10$ & 37.2 & $\begin{array}{c}5 \\
(1956-1960) \\
\end{array}$ & $2.3 \times 10^{5}$ & 47.48 & 1.28 \\
\hline $216-A-4$ & $6.10 \times 6.10$ & 37.2 & $\begin{array}{c}4 \\
(1955-1958)\end{array}$ & $6.21 \times 10^{6}$ & $1,552.31$ & 41.73 \\
\hline $216-A-5$ & $10.67 \times 10.67$ & 113.8 & $\begin{array}{c}8 \\
(1955-1961) \\
(1966)\end{array}$ & $1.63 \times 10^{9}$ & $2.04 \times 10^{5}$ & $1,791.60$ \\
\hline $216-A-10$ & $83.82 \times 13.72$ & $1,150.0$ & $23^{b}$ & $3.2 \times 10^{9}$ & $1.39 \times 10^{5}$ & 121.07 \\
\hline 216-A-21 & $18.29 \times 4.88$ & 89.3 & $\begin{array}{c}9 \\
(1957-1965)\end{array}$ & $7.79 \times 10^{7}$ & $8.66 \times 10^{3}$ & 96.98 \\
\hline 216-A-27 & $60.96 \times 3.05$ & 185.9 & $\begin{array}{c}6 \\
(1965-1970)\end{array}$ & $2.32 \times 10^{7}$ & $3.87 \times 10^{3}$ & 20.81 \\
\hline 217-A-31 & $21.34 \times 3.05$ & 65.1 & $\begin{array}{c}2 \\
(1964,1966)\end{array}$ & $1.0 \times 10^{4}$ & 5.11 & 0.08 \\
\hline $216-A-36 A$ & $30.48 \times 3.35$ & 102.1 & $\begin{array}{c}2 \\
(1965-1966)\end{array}$ & $1.07 \times 10^{6}$ & 536.92 & 5.26 \\
\hline \multicolumn{7}{|c|}{300 AREA } \\
\hline $316-3$ & $\begin{array}{c}183 \times 6 \\
\text { (both trenches) }\end{array}$ & $\begin{array}{l}1,830.0 \\
\text { (total) }\end{array}$ & $\begin{array}{c}11 \\
(1953-1963)\end{array}$ & $1.0 \times 10^{9}$ & $9.09 \times 10^{4}$ & $4.97 \times 10^{1}$ \\
\hline
\end{tabular}

a Two structures, each with these dimensions; area is total for both structures.

b Years of operation: 1956, 1961-1973, 1977-1978, 1981-1987. 
WHC-SD-LEF-ER-001, Rev. 0

Intentionaliy left blank.

4 
WHC-SD-LEF-ER-001, Rev. 0

\subsection{HYDROGEOLOGY}

The geology of the Hanford Site and the Pasco Basin has been characterized by Myers et al. (1979), DOE (1988), Delaney et al. (1991), and Reidel et al. (1992). Lindsey (1991) discussed the origin of the sediments overlying basalt bedrock and provided a detailed description of their stratigraphic relationships. Lindsey et al. (1992) described the geology and stratigraphy of suprabasalt sediments in the 200 East Area.

More recently, Lindsey and Mercer (1994) described the geology and hydrostratigraphy of the Low-Level Burial Grounds in the 200 Areas. Rohay et al. (1994) discussed the hydrogeology of the 200 West Area as it relates to contaminant migration through the vadose zone and groundwater. Slate (1996) described the lithology and distribution of the Plio-Pleistocene unit at the Hanford Site.

Discussion of the geology in this chapter focuses on the stratigraphy of the vadose zone. Within the 200 West Area, the distribution and hydraulic properties of the Plio-Pleistocene unit are of key importance because of this unit's effect on moisture movement in the vadose zone.

\subsection{HANFORD SITE}

The Hanford Site lies within the Columbia Plateau. The Columbia Plateau consists of a thick sequence of Miocene-age tholeiitic basalt flows comprising the Columbia River Basalt Group (CRBG) and an overlying mantle of late Miocene-to-Holocene sediments. The basalt flows have been folded and faulted during the past 17 million years, creating broad structural and topographic basins separated by asymmetric anticlinal ridges. Sediments up to $518 \mathrm{~m}(1,700 \mathrm{ft})$ thick have accumulated over the CRBG in some of these basins. These sediments are of late Miocene, Pliocene, and Pleistocene age. The Hanford Site is located within one of the larger basins, the Pasco Basin. The Pasco Basin is bounded on the north by the Saddle Mountains and on the south by Rattlesnake Mountain and the Rattlesnake Hills.

Principal stratigraphic units underlying the Hanford Site include, in ascending order, the CRBG (Miocene), Ringold Formation (Miocene-Pliocene), the Plio-Pleistocene unit, and the Pleistocene Hanford formation. A regionally discontinuous veneer of recent alluvium, colluvium, and/or eolian sediments overlies the principal geologic units. Figure 4-1 shows the general stratigraphy of the Hanford Site. Figure 4-2 depicts stratigraphic relationships and nomenclature of the sediments overiying basalt.

Sediments of the Ringold Formation are fluvio-lacustrine in origin and have been grouped into units according to facies (Figure 4-2). The Ringold Formation is absent from portions of the northeastern part of the Hanford Site, but is up to $185 \mathrm{~m}(\sim 600 \mathrm{ft})$ thick in the west-central part (Reidel et al. 1992). The dominant facies of the Ringold Formation are fluvial sand and gravel, finegrained sand, and silt and clay of stream overbank and lacustrine origin. Variable amounts of $\mathrm{CaCO}_{3}$ cementation occur in the Ringold Formation. 
Figure 4-1. Generalized Stratigraphy of the Hanford Site.

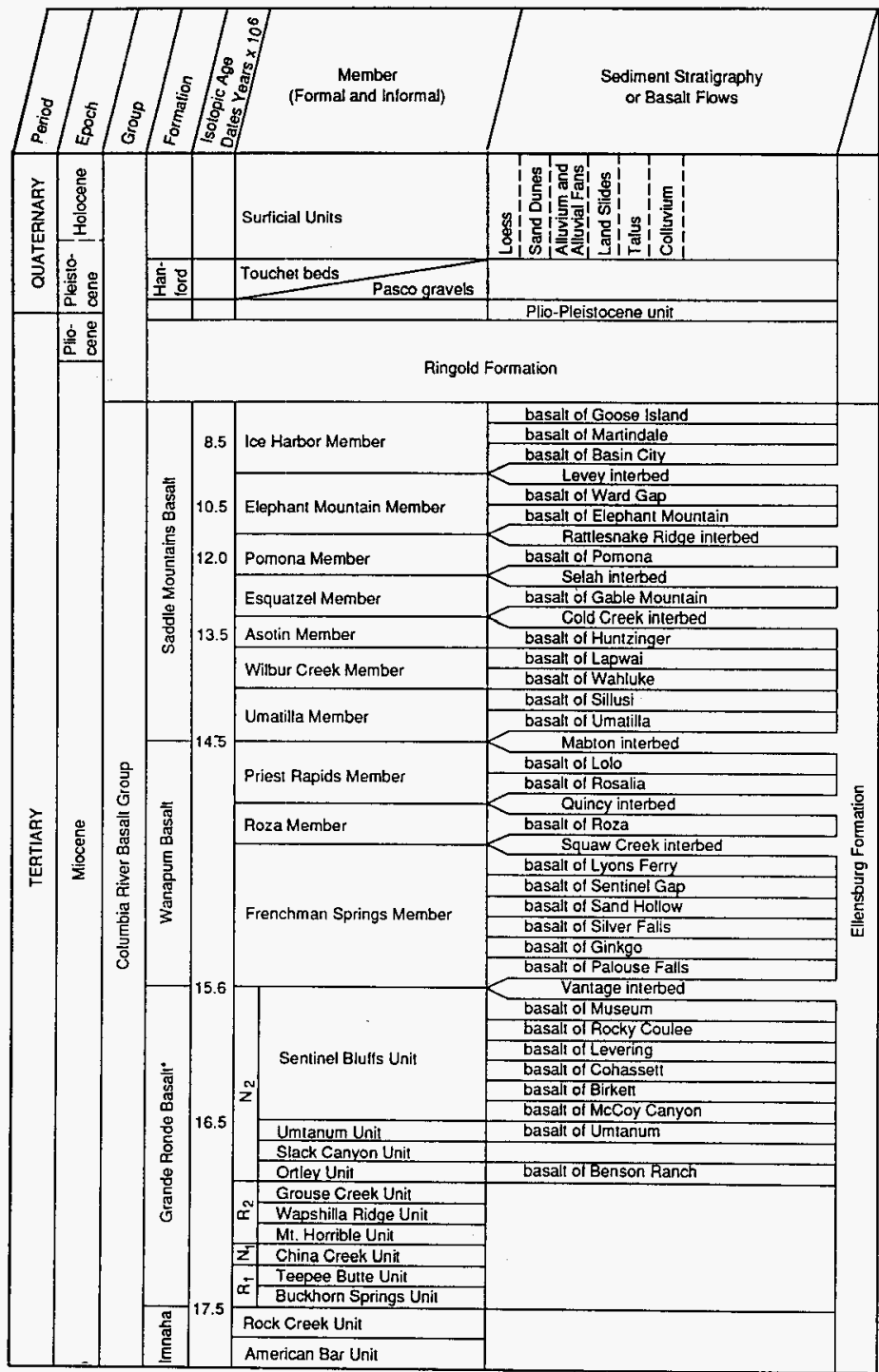

- The Grande Ronde Basalt consists of at least 120 major basalt flows. Only a few flows have been named. $N_{2}, R_{2}, N_{1}$ and $R_{1}$ are magnetostratigraph.t units. 
Figure 4-2. Stratigraphic Relationships of Sediments Above Basalt at the Hanford Site. (After Lindsey et al. 1992)

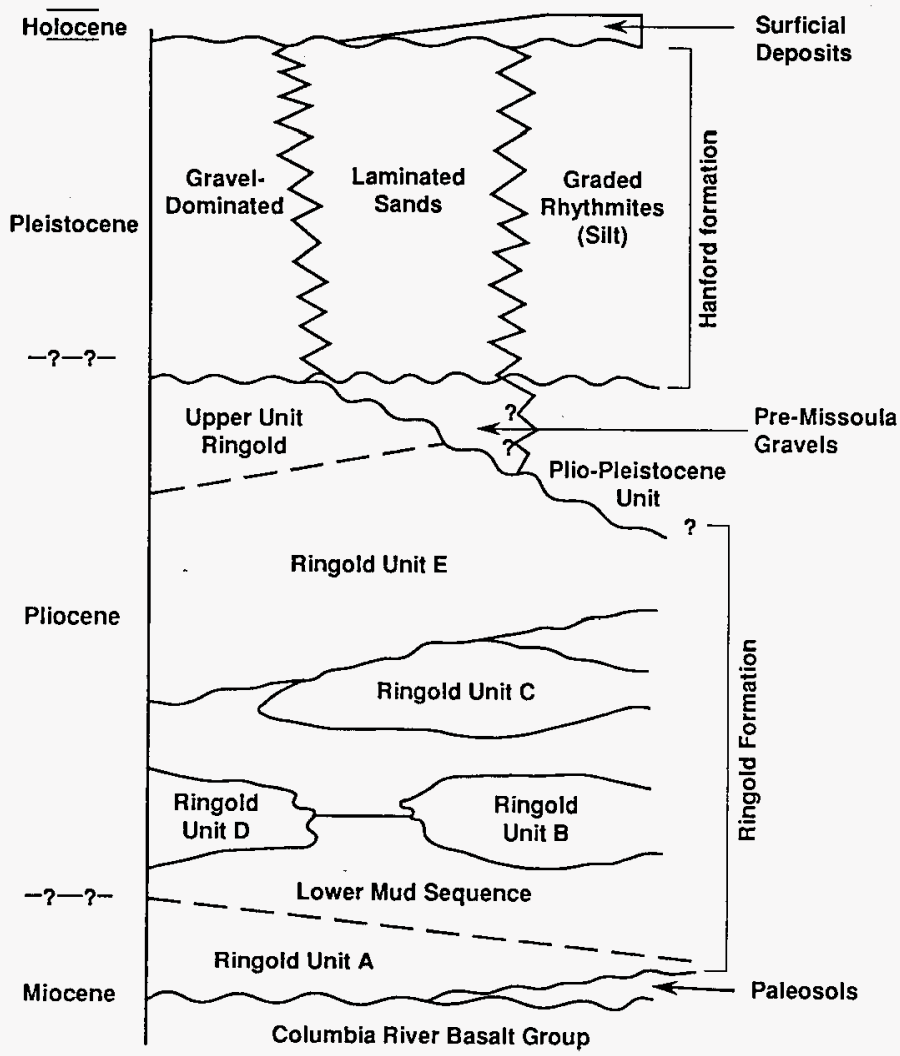

H96030149.14 
In the areas covered by this report, the Ringold Formation consists predominantly of sandy gravel to gravelly sand, with varying amounts of silt or clay. The Ringold Formation typically contains significantly more cementation and is more consolidated than corresponding lithologies in the younger Hanford formation. Thus, groundwater moves less readily in the Ringold Formation than within lithologies of comparable description in the Hanford formation.

The Plio-Pleistocene unit is defined in this report as all lithologies within the Hanford Site that overlie the Ringold Formation and underlie the Hanford formation. The unit is present only in the western parts of the Hanford Site, and is most thoroughly described from borehole logs in the 200 West Area.

Numerous observations from outcrops, boreholes, and excavations into the Plio-Pleistocene unit indicate that carbonate cementation (caliche) is highly variable laterally within the unit, and occurs as apparent lenticular bodies 3 to $9 \mathrm{~m}$ (10 to $30 \mathrm{ft}$ ) in lateral extent and 0.3 to $0.6 \mathrm{~m}$ ( 1 to $2 \mathrm{ft}$ ) thick. These qualities, and post-diagenetic fracturing, scouring by Missoula flood waters, and intrusion by clastic dikes (discordant tabular bodies of sediment) are known to introduce numerous, potentially-preferential routes for moisture infiltration through the Plio-Pleistocene unit (K. A. Lindsey and K. D. Reynolds of Westinghouse Hanford Company (WHC), personal communication, 1996). Based on information from cored intervals of boreholes in the 200 West Area, Slate (1996) described the caliche of the Plio-Pleistocene unit as a "persistent feature" in the 200 West Area of the Hanford Site, but of variable thickness and degree of development.

The Hanford formation consists of cataclysmic flood deposits of sand, gravel, and interbedded silt which, in aggregate, are up to $110 \mathrm{~m}(-350 \mathrm{ft})$ thick. Hanford formation sediments typically are less consolidated than Ringold Formation sediments and open-framework gravel is common (Reidel et al. 1992). The Hanford formation is informally subdivided into three principal facies: gravel-dominated (pebble to boulder in size), sand-dominated, and silty.

\subsection{DISCHARGE SITES IN THE 200 WEST AREA}

Five lithologic logs were selected to depict the suprabasalt stratigraphy in the 200 West Area. The locations of the logged wells are shown in Figure 3-1. The wells were selected based on proximity to the discharge sites of interest, completeness of the logs, and ability to illustrate the lateral variation of stratigraphy in the 200 West Area. General stratigraphic profiles at these wells are shown in Figure 4-3.

The Plio-Pleistocene unit is of particular importance in the 200 West Area because of its low permeability. As discussed in Section 4.1, this unit occurs throughout the 200 West Area, but the degree of caliche development is highly variable. The caliche and clay content of this unit are the principal factors that promote lateral, rather than vertical flow of moisture. Figure 4-3 illustrates the variability in thickness and dominant grain size of the Plio-Pleistocene unit. Boundaries between this unit, the overlying Hanford formation, and underlying Ringold Formation are occasionally poorly defined by lithologic logs. Hence, Figure 4-3 portrays the interpreted thicknesses of the PlioPleistocene unit in these wells. 


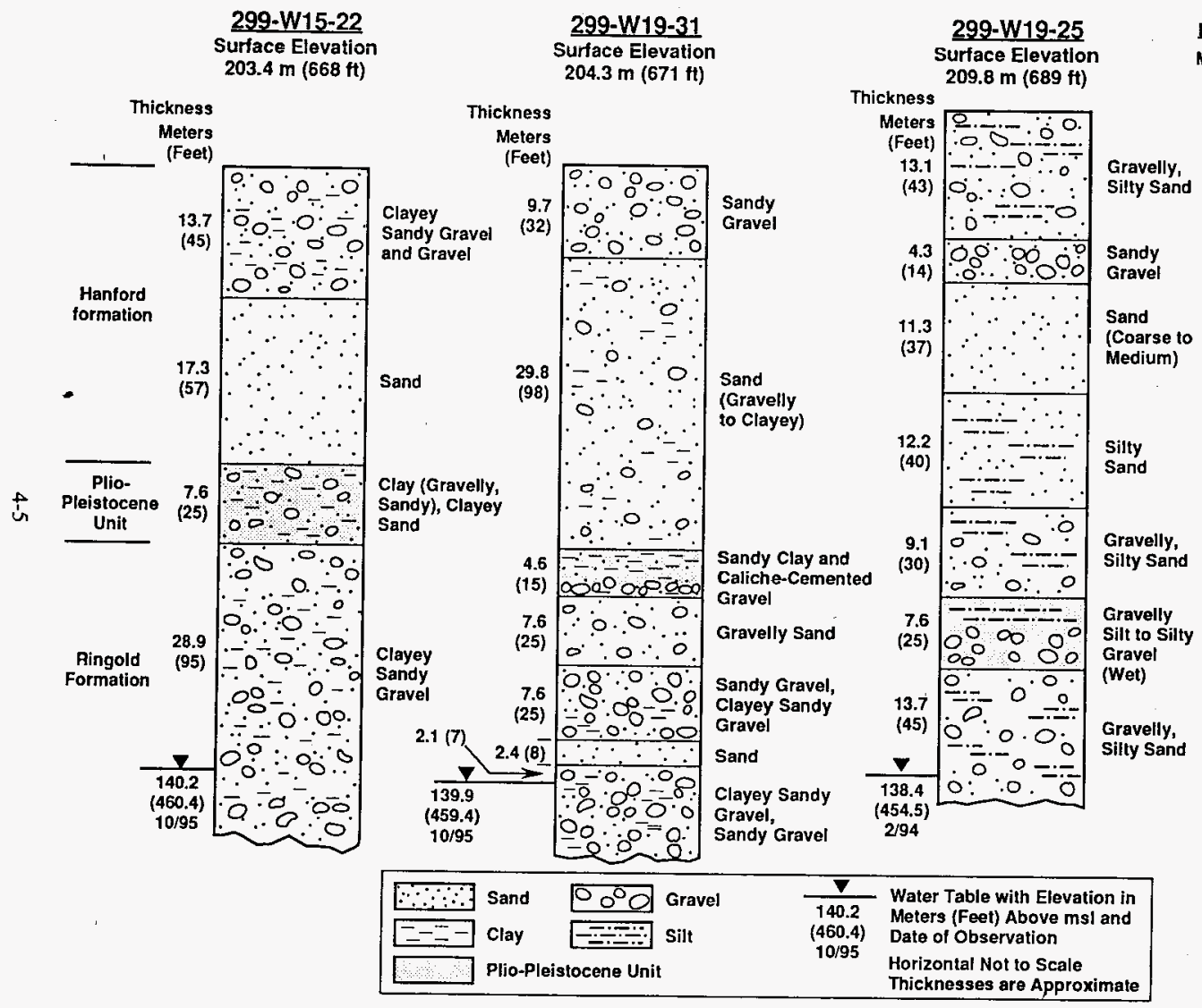



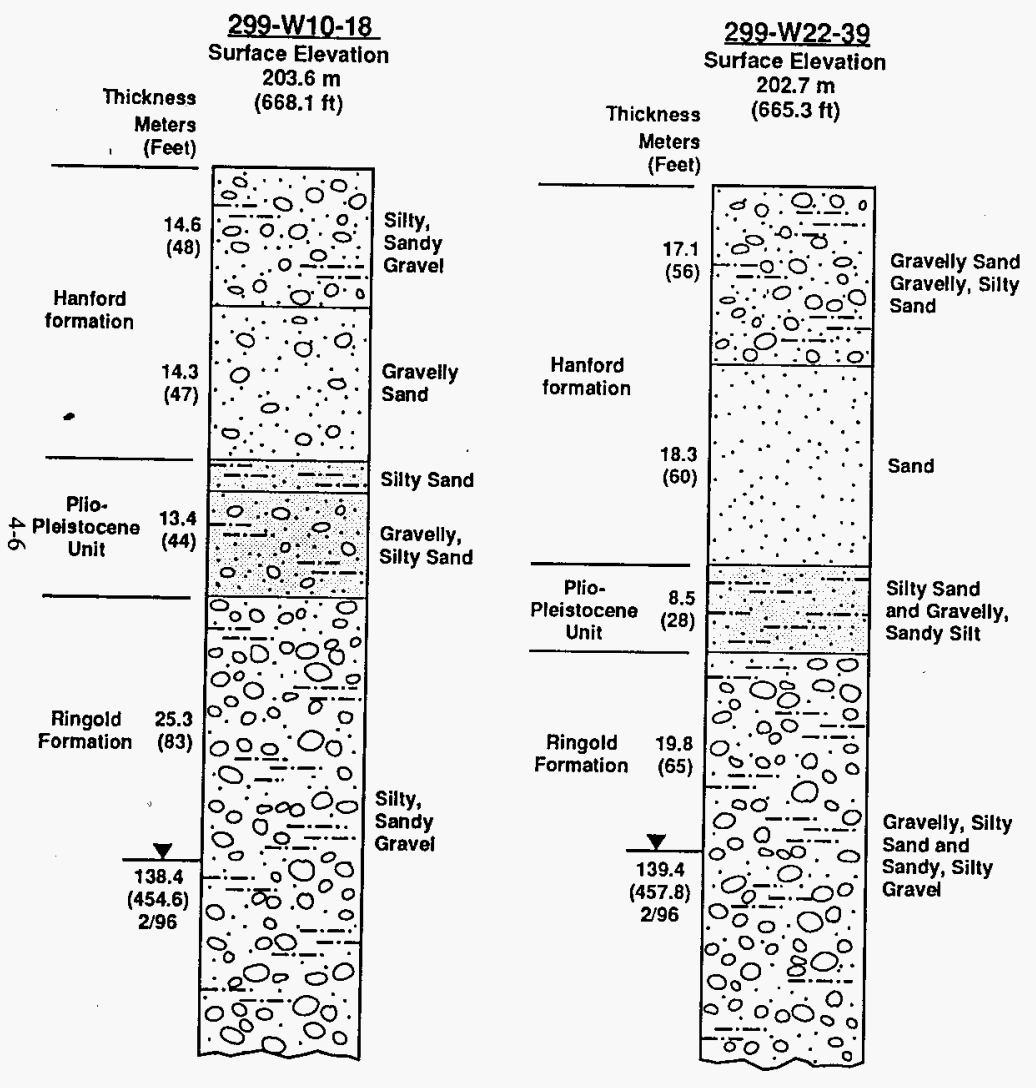

Flevation (ms)

Meters Feet

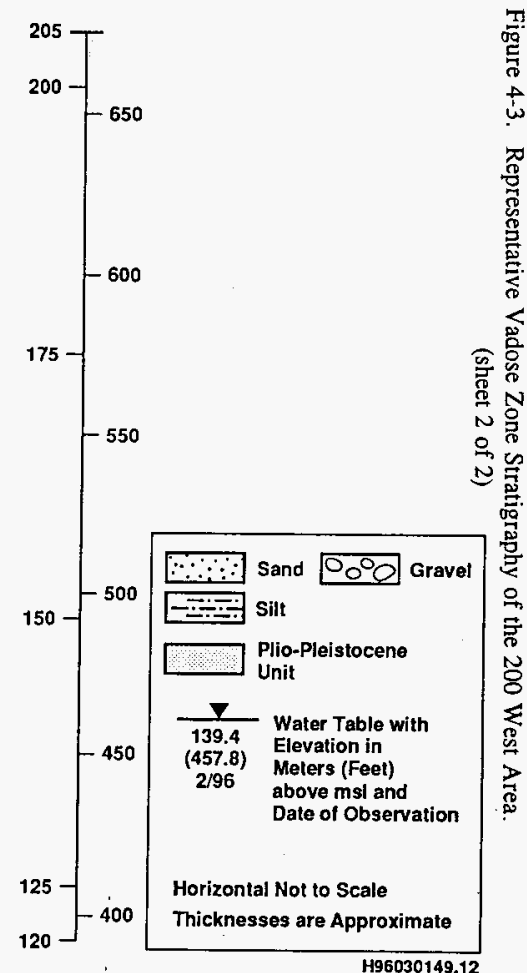

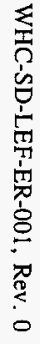


Rohay et al. (1994) identified several wells immediately adjacent to the 216-Z-20 Trench, 216-Z-21 Pond, and 216-Z-9 Crib ( $~ 300 \mathrm{~m}$ [984 ft] southeast of Z Plant), within which perched water was observed either during drilling of the wells or following remediation activities. Based on comparison of well logs and reports of perched water, the caliche of the Plio-Pleistocene unit beneath these facilities appears to be less permeable than elsewhere in the 200 West Area. Rohay et al. (1994) speculated that groundwater in this perched horizon was of recent origin, based on infiltration calculations by Wright et al. (1994). Last and Rohay (1993) predicted, based on modeling of the 216-Z-21 Pond discharges, that infiltrating moisture from past-practice facilities in this area would spread a maximum of $-62 \mathrm{~m}(203 \mathrm{ft})$.

Based on data from boreholes drilled for infiltration testing near the 200 Areas Effluent Treatment Facility (ETF) disposal site (see Figure 3-1), Swanson (1994) reported significant differences in the permeability of the Plio-Pleistocene unit between two test borings drilled $\sim 38 \mathrm{~m}$ $(125 \mathrm{ft})$ apart. Falling-head infiltration tests suggested an order-of-magnitude difference in infiltration capacity of the Plio-Pleistocene unit between the two locations. Bjornstad (1990) also described the carbonate cementation and caliche of the Plio-Pleistocene unit at the northern edge of the 200 West Area as variable in thickness and degree of development, and identified noncalcareous sand lenses within the unit.

These observed variations in the Plio-Pleistocene unit imply that there are significant lateral changes in the permeability of the unit in the 200 West Area. The unit's pervasive cementation in the southwest corner of the 200 West Area (Rohay et al. 1994) may be a local exception to the otherwise discontinuous aspect of the carbonate cementation.

Depth to the water table from the surface in the 200 West Area generally ranges from $<61 \mathrm{~m}(200 \mathrm{ft})$ at the southwest edge of the area, to $>76 \mathrm{~m}(250 \mathrm{ft})$ at the eastern edge. The water table beneath the 200 West Area invariably occurs below the Plio-Pleistocene unit and within the Ringold Formation.

\subsection{DISCHARGE SITES IN THE 200 EAST AREA}

The locations of wells selected to stratigraphically represent the 200 East Area for the areas nearest to stream discharge sites in vicinity of the B Plant and PUREX Plant are shown in Figures 3-8 and 3-9. Lithologic logs of these wells are summarized in Figure 4-4.

Vadose zone stratigraphy of both locations in the 200 East Area is dominated by the Hanford formation upper sand unit. Relatively thin layers of gravel and gravelly sand are intercalated with the dominant sand layer. The Hanford formation is $-84 \mathrm{~m}(275 \mathrm{ft})$ thick near the PUREX Plant and $-72 \mathrm{~m}(235 \mathrm{ft})$ thick near B Plant.

The Ringold Formation is relatively thin between the bottom of the Hanford formation and the water table in the vicinities of both PUREX and B Plants. Near B Plant, the Ringold Formation consists of $-23 \cdot \mathrm{m}$ ( $75 \mathrm{ft}$ ) of sandy gravel. Near the PUREX Plant the Ringold Formation consists of $7.6 \mathrm{~m}(25 \mathrm{ft})$ of mostly gravelly, sandy silt and clay, with a thinner (4.3 m [14 ft]) layer of sandy gravel below. The Plio-Pleistocene unit is absent in the 200 East Area. The Ringold Formation silt/clay sequence near the PUREX Plant is a similar, relatively impermeable layer, but lacks the calcareous cementation and carbonate paleosols of the Plio-Pleistocene unit. 

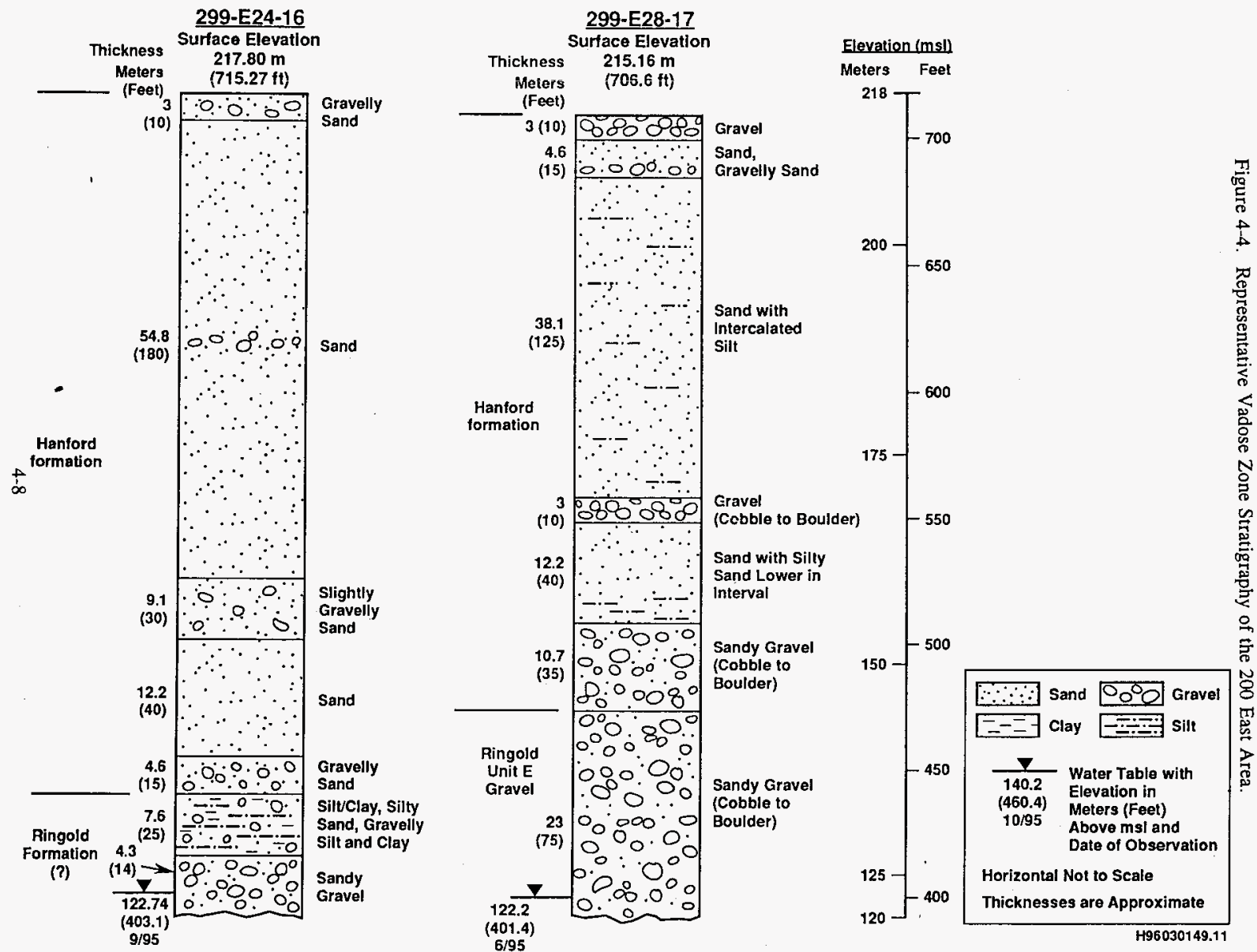
Depth to the water table from the surface in the 200 East Area ranges from $<61 \mathrm{~m}(200 \mathrm{ft}$ ) in the northeast corner, to $>91 \mathrm{~m}(300 \mathrm{ft})$ in the western and southern portions. Current depths to the water table near the B and PUREX Plants are $-93 \mathrm{~m}(304 \mathrm{ft})$ and $96 \mathrm{~m}(315 \mathrm{ft})$, respectively.

\subsection{DISCHARGE SITES IN THE 300 AREA}

The stratigraphy of the vadose zone in the vicinity of the discharge sites in the 300 Area is illustrated in Figure 4-5. The columnar section shown is a composite based on data from five wells in the immediate vicinity of the discharge sites. Wells nearest the trenches penetrated backfilled material in the upper 6 to $7.6 \mathrm{~m} \mathrm{(20} \mathrm{to} 25 \mathrm{ft}$ ) of drilling. For this reason, the nearby wells were selected to obtain representative lithologies for this missing layer of sediment. The well locations, relative to the 316-3 Trenches and streams discharge sites, are shown in Figure 3-10.

The stratigraphy and hydrogeology of the 300 Area were analyzed in detail by Schalla et al. (1988), Gaylord and Poeter (1991), and Swanson (1992).

The vadose zone at the 300 Area discharge sites is entirely within the sandy gravel facies of the Hanford formation. The sandy gravel includes minor amounts of silt and clay. Depth to the water table is $\sim 15 \mathrm{~m}(50 \mathrm{ft})$ at this location, although daily and seasonal fluctuations may occur because of changes in river stage. The fluctuations are slight $(<0.1 \mathrm{~m}[<0.3 \mathrm{ft}])$, but may produce temporary reversals in groundwater flow direction (Lindberg 1995). 
Figure 4-5. Representative Vadose Zone Stratigraphy of the 300 Area.

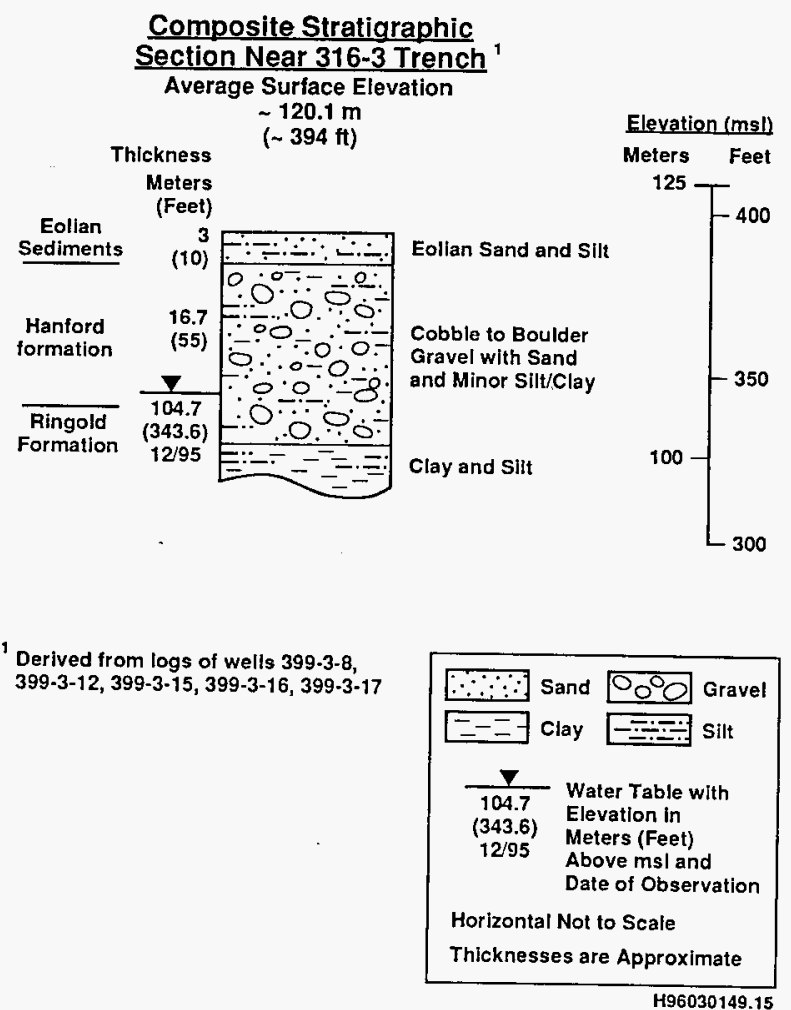




\subsection{NUMERICAL MODEL INPUT PARAMETERS}

Lateral spreading in the subsurface of the past-practice effluent discharged within $300 \mathrm{ft}$ (92 $\mathrm{m}$ ) of a miscellaneous stream discharge was modeled as two-dimensional vertical cross sections. The cross sections extended from the centerlines of the past-practice discharge facilities toward the site(s) of the miscellaneous stream discharge(s). As noted in Chapter 2.0, the past-practice discharges were grouped according to relative intensity of effluent discharge during the facility's operation. For purposes of conservatism, movement of the effluent was simulated for the maximum-dischargevolume facility in each group, except for one case in which the maximum-discharge-rate facility was simulated (see Section 5.2.1).

The values required by the numerical model to define the hydraulic properties of the Ringold unit E, Hanford sand, Hanford gravel, and the Plio-Pleistocene unit were obtained from available information (Connelly et al. 1992) and are discussed in detail in the sections that follow. Historical information on the durations, rates, and volumes of past-practice discharges in the vicinity of current stream discharges was summarized in Tables 3-1 and 3-2 of Chapter 3.0.

\subsection{WEST AREA}

Twelve past-practice discharges were of interest in the 200 West Area because of their proximity to stream discharges. These discharges include one near the 222-S Laboratory, three east of the 241-S and 241-SX Tank Farms, one near the 200 West Maintenance Area, two near the $\mathrm{Z}$ Plant, and five near the 231-Z Building (see Table 3-1).

\subsubsection{Sources}

As noted in Chapter 2.0, for purposes of modeling, each historic discharge of interest was evaluated with respect to (1) total volume discharged during the facility's operating life, (2) the average operating discharge rate, and (3) the vertical flux density (i.e., the ratio of the rate of discharge to the surface area through which vertical infiltration of the discharge occurred).

The total volume of effluent discharged to each 200 West Area facility of interest is shown in Figure 5-1. The rate of discharge to each facility, calculated by dividing the volume of discharge by the duration of facility operation, is shown in Figure 5-2. The flux density (as defined above) is shown in Figure 5-3. Representative miscellaneous stream discharges are shown in the three figures for purposes of comparison.

Two representative surface areas were chosen to simulate the miscellaneous stream discharges. A surface area of $20 \mathrm{ft} \times 20 \mathrm{ft}(6 \mathrm{~m} \mathrm{x} 6 \mathrm{~m})$ was selected to facilitate analysis by the numerical methods. An area $4 \mathrm{ft} \times 4 \mathrm{ft}(1.2 \mathrm{~m} \mathrm{x} 1.2 \mathrm{~m})$ was used to verify that the results were essentially insensitive to the area of discharge.

As noted in Figure 5-1, the 12 facilities were characterized in terms of two broad groupings according to relative volumes of discharge. The figures depicting the relative discharge rates and flux densities confirm these two groupings. The $\mathrm{S} 20, \mathrm{Z6}$, and $\mathrm{Z4}$ facilities are in a relatively low-volume discharge group. The LWC, U16, Z1, Z16, S09, Z17, S23, and Z5 facilities are in a higher-volume discharge group. 


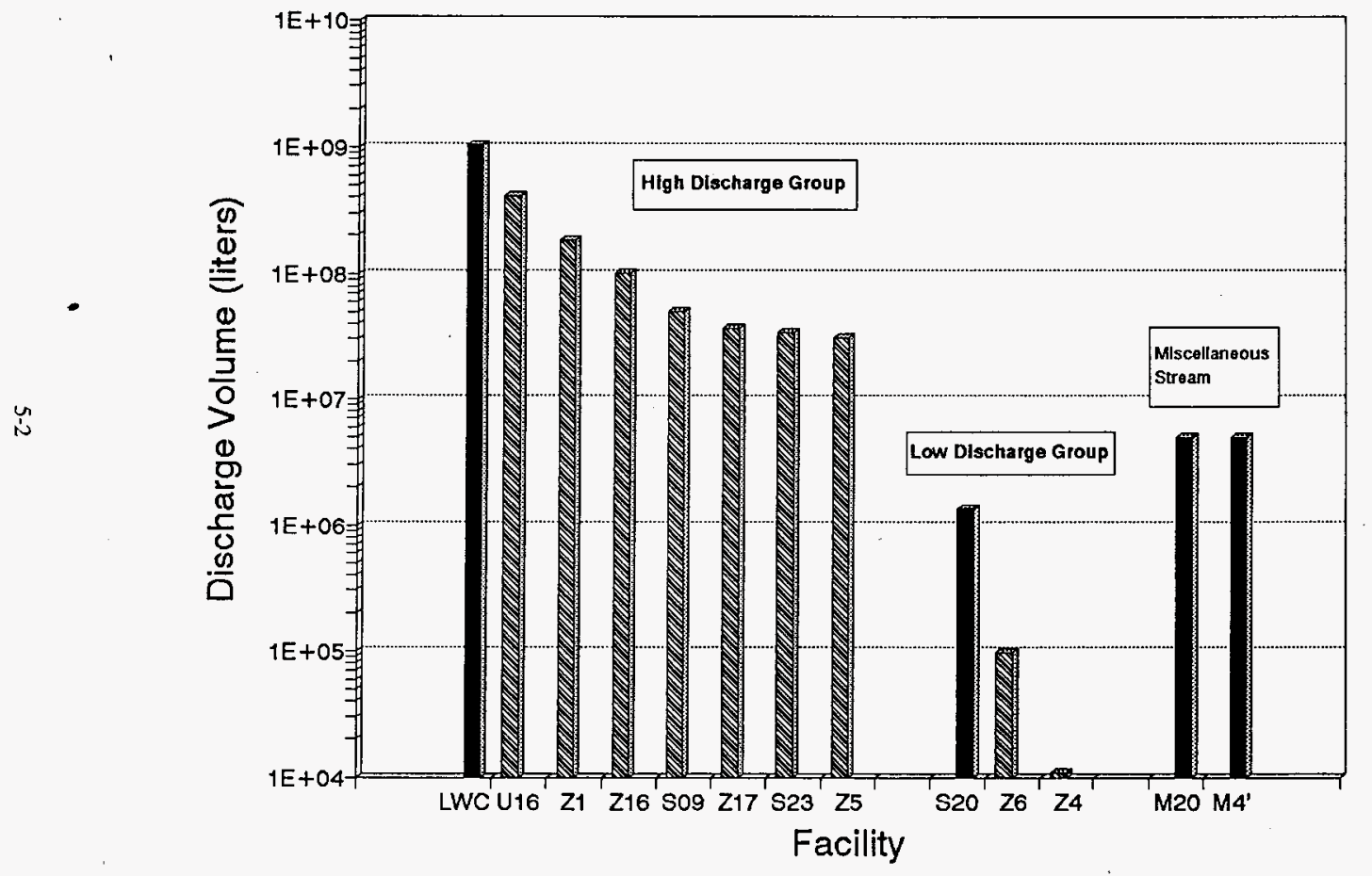


WHC-SD-LEF-ER-001, Rev. 0

Figure 5-2. Discharge Rates for the 200 West Area Facilities.

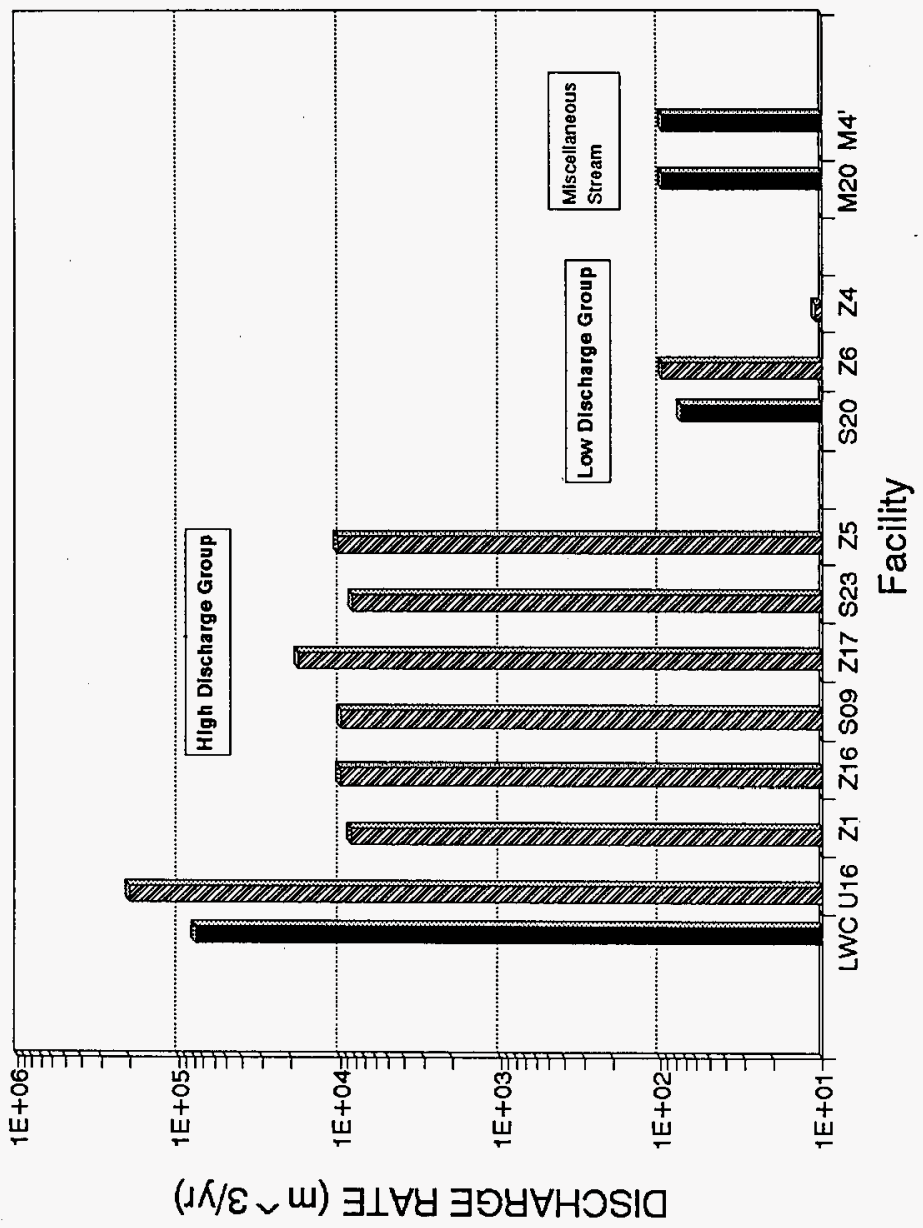


WHC-SD-LEF-ER-001, Rev. 0

Figure 5-3. Flux Densities for the 200 West Area Facilities.

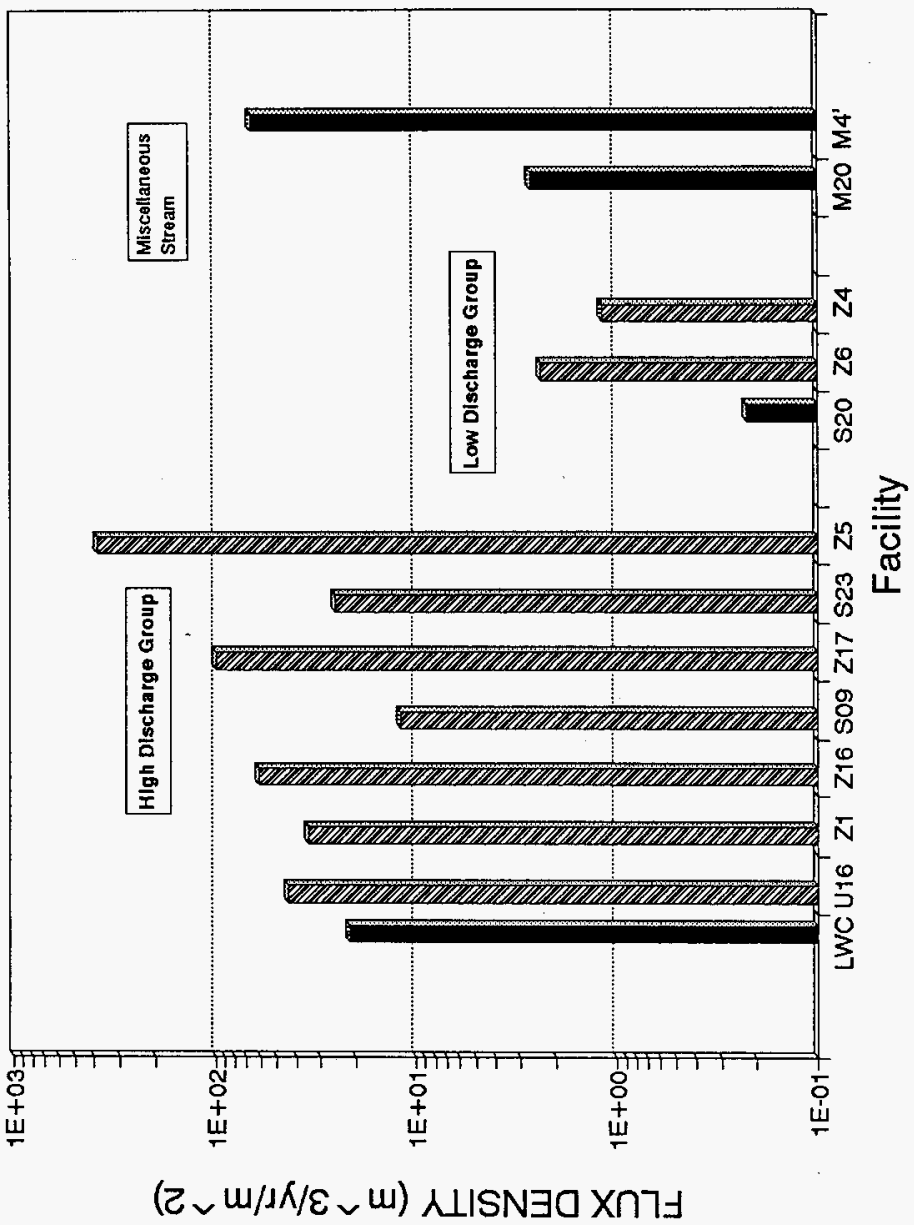


To reduce the amount of modeling required and introduce a degree of conservatism to the analysis, only the highest discharge-volume facility was considered to be representative of all lowervolume discharge facilities in that group. Hence, the 216-W-LWC Crib was chosen to represent the other eight facilities with relatively large volumes of discharge, and the S20 facility was chosen to represent the other two facilities with relatively low-volume discharges. Accordingly, the discharge source terms in the numerical model for the 200 West Area incorporated the volumes, discharge rates, and flux densities of these two facilities.

\subsubsection{Model Geometry}

The model geometry for the 200 West Area was determined after examining lithologic logs and developing stratigraphic sections. The five stratigraphic sections that best represent the sites of interest were discussed in Section 4.2. One section was selected for representation by the model. The stratigraphy was simplified by combining lithologies that are known to have similar properties, or for which sediment property information was insufficient to justify separate consideration. The stratigraphy portrayed by the model was shown in Figure 4-3 and consists of the following four horizontal units:

- Hanford formation gravel unit

- Hanford formation sand unit

- Plio-Pleistocene unit

- Ringold formation unit $\mathrm{E}$ from 0 to $32 \mathrm{ft}$ ( $32 \mathrm{ft}$ thick)

from 32 to $130 \mathrm{ft}(98 \mathrm{ft}$ thick)

from 130 to $145 \mathrm{ft}$ ( $15 \mathrm{ft}$ thick)

from 145 to $212 \mathrm{ft}$ ( $67 \mathrm{ft}$ thick).

Figure 5-4 illustrates the grid (or mesh) used to discretize the model for analysis of pastpractice discharges to the 216-W-LWC Crib. Four clusters of closely spaced vertical lines are shown in Figure 5-4. The cluster nearest to the center of the crib is a refinement of the mesh in an area that represents the end of the crib. This refinement is needed because of the high contrast in boundary conditions that occurs in this area -- from high artificial discharge conditions on one side to natural recharge conditions on the other side. The other three vertical-line clusters are needed to depict discontinuities in the caliche of the Plio-Pleistocene unit and the accompanying high contrasts in hydraulic properties.

Closely-spaced horizontal lines at the lithologic unit interfaces are refinements of the mesh that are needed to represent high contrasts in hydraulic properties at the contacts between different lithologies. Closely-spaced horizontal lines at the top of the spatial domain are refinements of the mesh that are needed to simulate the rapid introduction of large volumes of water into relatively dry sediments. Closely-spaced horizontal lines at the bottom of the spatial domain are refinements of the mesh that are needed to simulate the transition from relatively dry strata in the vadose zone to saturated conditions in the uppermost aquifer.

Figure 5-4 also identifies the saturated vertical hydraulic conductivities of the four lithologies that were modeled to illustrate their variability. (For unsaturated conditions, the hydraulic conductivities can vary by orders of magnitude.)

Different meshes were generated as needed to model other facilities. The horizontal mesh lines remained the same for all 200 West Area models. The number and locations of vertical mesh lines were adjusted to simultaneously minimize the size of the model and provide adequate coverage of the modeling domain. The meshes used to model facilities, other than the 216-W-LWC Crib, did not portray discontinuities in the Plio-Pleistocene unit. 
WHC-SD-LEF-ER-001, Rev. 0

Figure 5-4. Model Geometry for the 200 West Area Facilities.

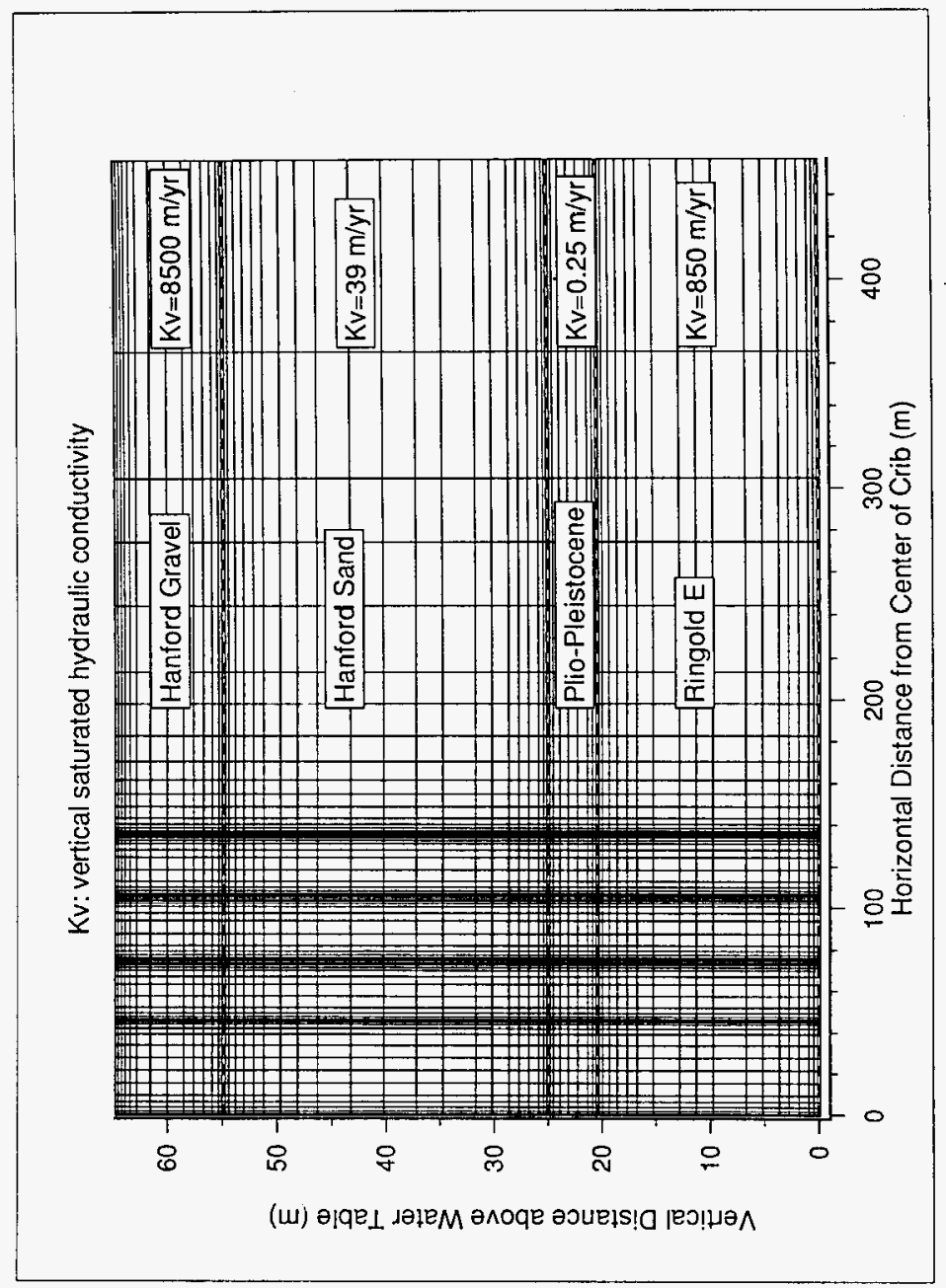




\subsubsection{Hydraulic Properties}

Soil hydraulic properties were obtained from two published reports; Hydrogeologic Model for the 200 West Groundwater Aggregate Area (Connelly et al. 1992) and Variability and Scaling of Hydraulic Properties for 200 Area Soils, Hanford Site (Khaleel and Freeman 1995). Adjustments were made where errors were detected in the values reported by Khaleel and Freeman (1995). (Details are provided in the discussions that follow for each stratigraphic unit.) The adjusted values are shown in Table 5-1.

Table 5-1. Adjusted Hydraulic Properties Used as Input Values for the 200 West Area Sediments.

\begin{tabular}{|c|c|c|c|c|c|}
\hline Sediment Type & $\begin{array}{c}\text { Saturated } \\
\text { Hydraulic } \\
\text { Conductivity } \\
(\mathrm{m} / \mathrm{yr}) \\
\end{array}$ & $\begin{array}{c}\text { Effective } \\
\text { Porosity } \\
(\mathrm{cc} / \mathrm{cc})\end{array}$ & $\begin{array}{l}\text { Residual } \\
\text { Moisture } \\
\text { Content } \\
\text { (cc/cc) } \\
\end{array}$ & $\begin{array}{l}\text { van Genuchten } \\
\text { parameters: } \\
\text { alpha }\left(\mathrm{cm}^{-1}\right) \\
\text { n (unitless) }\end{array}$ & $\begin{array}{c}\text { Dry Bulk } \\
\text { Density } \\
\text { (g/cc) }\end{array}$ \\
\hline Hanford gravel & $\begin{array}{rr}V \quad 8515.0 \\
\text { H } 17030.0 \\
\end{array}$ & .193 & .05 & $\begin{array}{c}.2785 \\
1.3713 \\
\end{array}$ & 2.15 \\
\hline Hanford sand & $\begin{array}{cc}\text { V } & 39.42 \\
\text { H } & 394.2 \\
\end{array}$ & .1864 & .041 & $\begin{array}{l}.1060 \\
1.4734 \\
\end{array}$ & 1.6 \\
\hline $\begin{array}{l}\text { Plio-Pleistocene } \\
\text { unit }\end{array}$ & $\begin{array}{ll}\mathrm{V} & 0.2476 \\
\mathrm{H} & 2.476 \\
\end{array}$ & .2341 & .078 & $\begin{array}{r}.0049 \\
1.7721 \\
\end{array}$ & 1.6 \\
\hline $\begin{array}{l}\text { Ringold } \\
\text { unit } E\end{array}$ & $\begin{array}{lr}\text { V } & 851.5 \\
\text { H } & 8515.0\end{array}$ & .132 & .067 & $\begin{array}{c}.1045 \\
1.4913\end{array}$ & 2.0 \\
\hline
\end{tabular}

$\mathrm{V}=$ vertical $\quad \mathrm{H}=$ horizontal

\section{Hanford Gravel}

Hydraulic properties of Hanford gravel were represented by a sample collected from well 299-W10-13 at a depth of $80 \mathrm{ft}(24.4 \mathrm{~m}$ ) (see Connelly et al. 1992, page A.56). The curve for the van Genuchten parameters very closely fit the data (Figure 5-5), and the saturated hydraulic conductivity $(2.7 \mathrm{E}-2 \mathrm{~cm} / \mathrm{s})$ was within the range expected for gravels.

Connelly et al. (1992) did not correct volumetric results for gravel content. In an earlier report, Bjornstad (1990, page C.36) reported that the sample from well 299-W10-13 had a $63.5 \%$ gravel content by weight, and that samples were prepared in the laboratory for water retention analyses by recompacting to a dry bulk density of $1.6 \mathrm{~g} / \mathrm{cc}$ (page 2.18). Khaleel and Freeman (1995) corrected for gravel content, but they used the laboratory dry bulk density in the Gardner correction equation, rather than the required field dry bulk density.

Because the field dry bulk densities were not directly measured, estimates were prepared. Results from approximately 34 samples collected from the Hanford Site for determination of unsaturated hydraulic conductivity and moisture retention were obtained from WHC's physical properties laboratory. The relationship between the percentage of gravel (by weight) and the dry bulk density was graphed (Figure 5-6). Average bulk densities for ranges of gravel contents were selected using Figure 5-6. For gravel contents from $20 \%$ to $40 \%$, four values were available that were fairly evenly distributed about a density of 2.0; consequently, a value of 2.0 was selected (Table 5-2). For higher gravel contents, the densities increased substantially. 


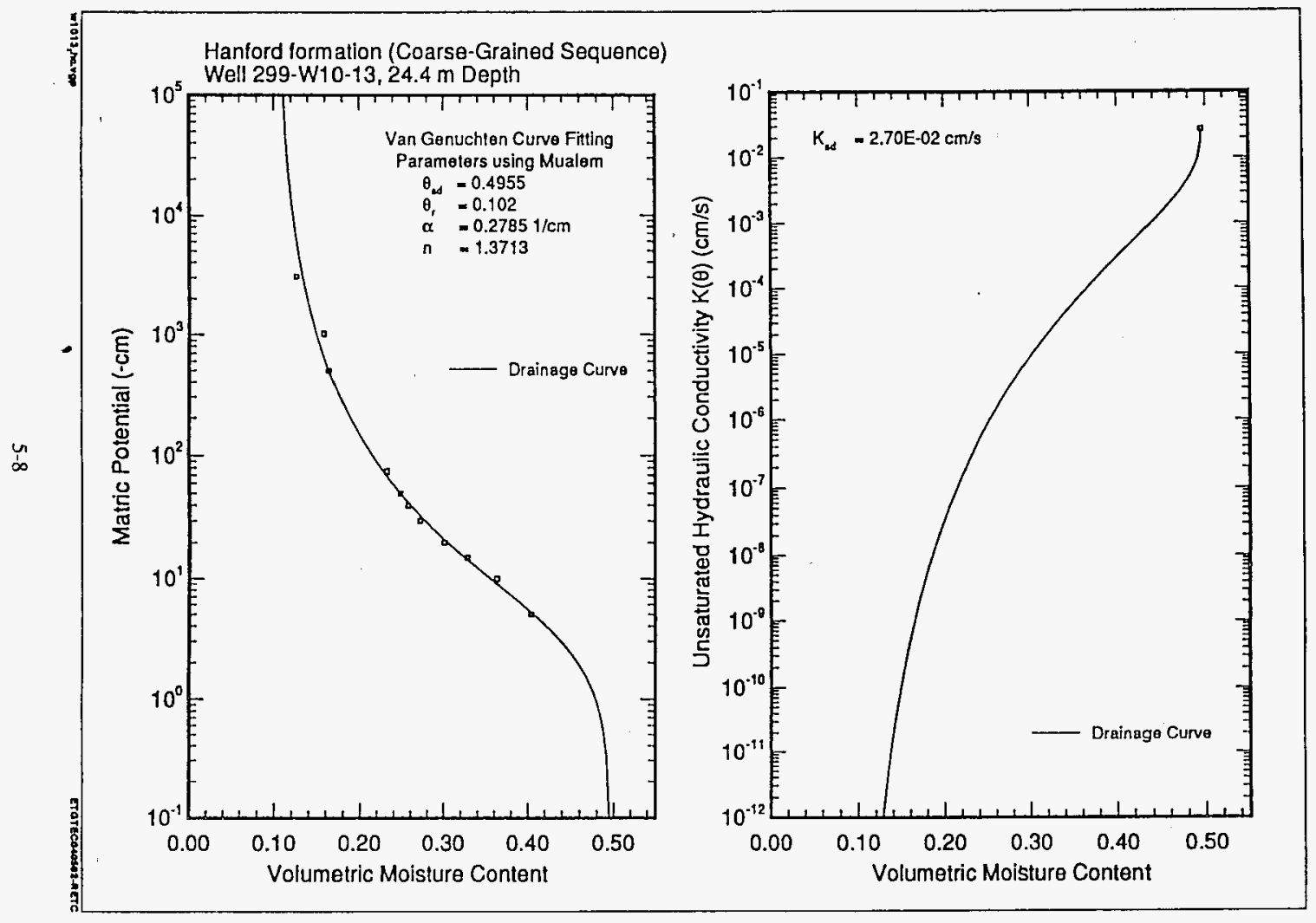

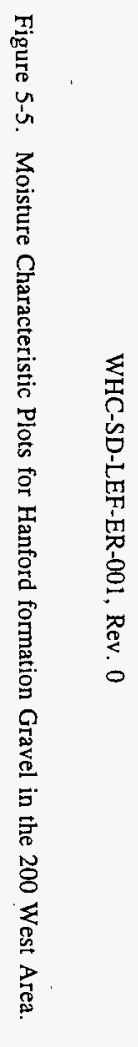


WHC-SD-LEF-ER-001, Rev. 0

Figure 5-6. Dry Bulk Density of Gravelly Sediments as a Function of Gravel Content.

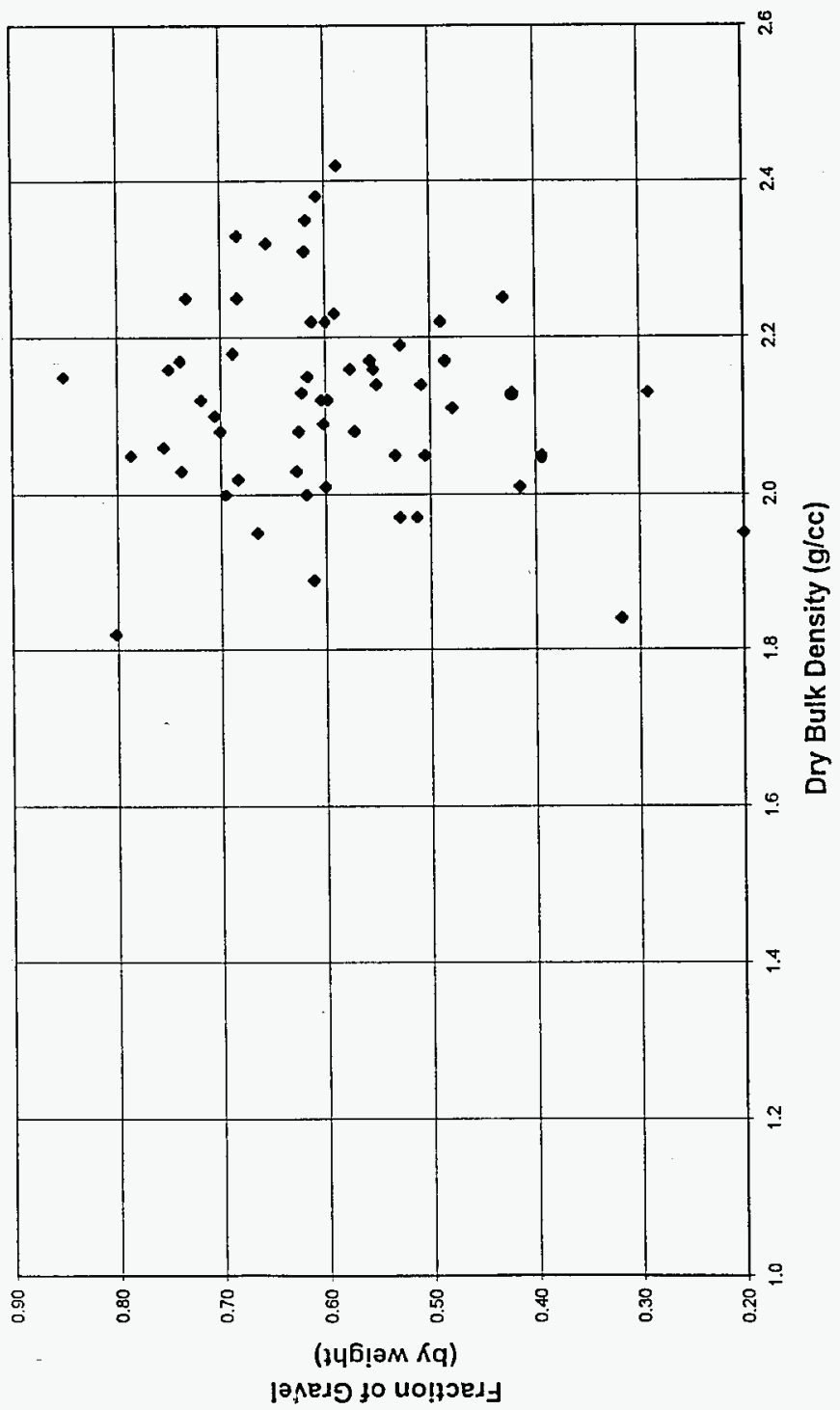


Table 5-2. Comparison of Average Dry Bulk Densities with Gravel Contents.

\begin{tabular}{||c|c|}
\hline Gravel Content (Range in \% weight) & Average Dry Bulk Density $(\mathrm{g} / \mathrm{cc})$ \\
\hline $20 \%$ to $<40 \%$ & 2.00 \\
\hline $40 \%$ to $<60 \%$ & 2.10 \\
\hline $60 \%$ to $<80 \%$ & 2.15 \\
\hline
\end{tabular}

Because an increase in gravel content should theoretically increase the bulk density, values of 2.10 and 2.15 were selected for gravel ranges from $40 \%$ to $60 \%$ and $60 \%$ to $80 \%$, respectively. (Some relatively low density values at the highest gravel content may be caused by open-framework gravels, which were not considered to be present for purposes of these analyses.)

The values in Table 5-2 were used only when no in situ dry bulk density measurements had been made. For example, for a gravel content of $63.5 \%$, an average field dry bulk density of 2.15 was used to correct the volumetric laboratory results to the values shown in Table 5-1.

\section{Hanford Sand}

The hydraulic properties for the Hanford sand unit were represented by a sample collected from well 299-W15-2 at a depth of $30.5 \mathrm{~m}$ (100 ft) (Connelly et al. 1992, page A.42). The wetting curve for this sample was used because it represents the processes of interest (i.e., the wetting of the sediments) better than the drying curve. The wetting curve, when available, was used for all samples. The curve for the van Genuchten parameters closely fit the data (Figure 5-7), and the saturated hydraulic conductivity $(1.25 \mathrm{E}-4 \mathrm{~cm} / \mathrm{s})$ was within the range expected for sands. No gravel adjustment was made for the Hanford sand unit because the gravel content was only $3.5 \%$ by weight.

\section{Plio-Pleistocene Unit}

Hydraulic properties of the Plio-Pleistocene unit were represented by a sample collected from well $299-W 15-2$ at a depth of $36.6 \mathrm{~m}$ (120 ft) (Connelly et al. 1992, page A.35). The wetting curve for this sample was used. The curve for the van Genuchten parameters fit the data closely, particularly at the wet end of the curve (Figure 5-8). The saturated hydraulic conductivity $(7.85 \mathrm{E}-7 \mathrm{~cm} / \mathrm{s})$ is low relative to saturated values used in the model for the other lithologies, but it is within the range expected for caliche and clays. No gravel adjustment was made because the gravel content was only $0.9 \%$ by weight.

\section{$\underline{\text { Ringold Unit E }}$}

The Ringold unit E hydraulic properties were represented by a sample collected from well

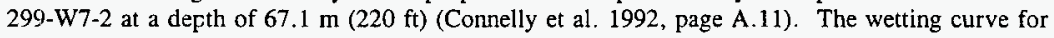
this sample was used. The curve for the van Genuchten parameters closely fit the data, particularly at the wet end of the curve (Figure 5-9). The saturated hydraulic conductivity $(2.7 \mathrm{E}-3 \mathrm{~cm} / \mathrm{s}$ ) is within the range expected for the Ringold unit E gravels.

Gravel adjustments were made using an average field dry bulk density of $2 \mathrm{~g} / \mathrm{cc}$ (see Table 5-2) and by applying the corrections previously discussed for the Hanford gravels. These adjustments produced the values listed in Table 5-1. 

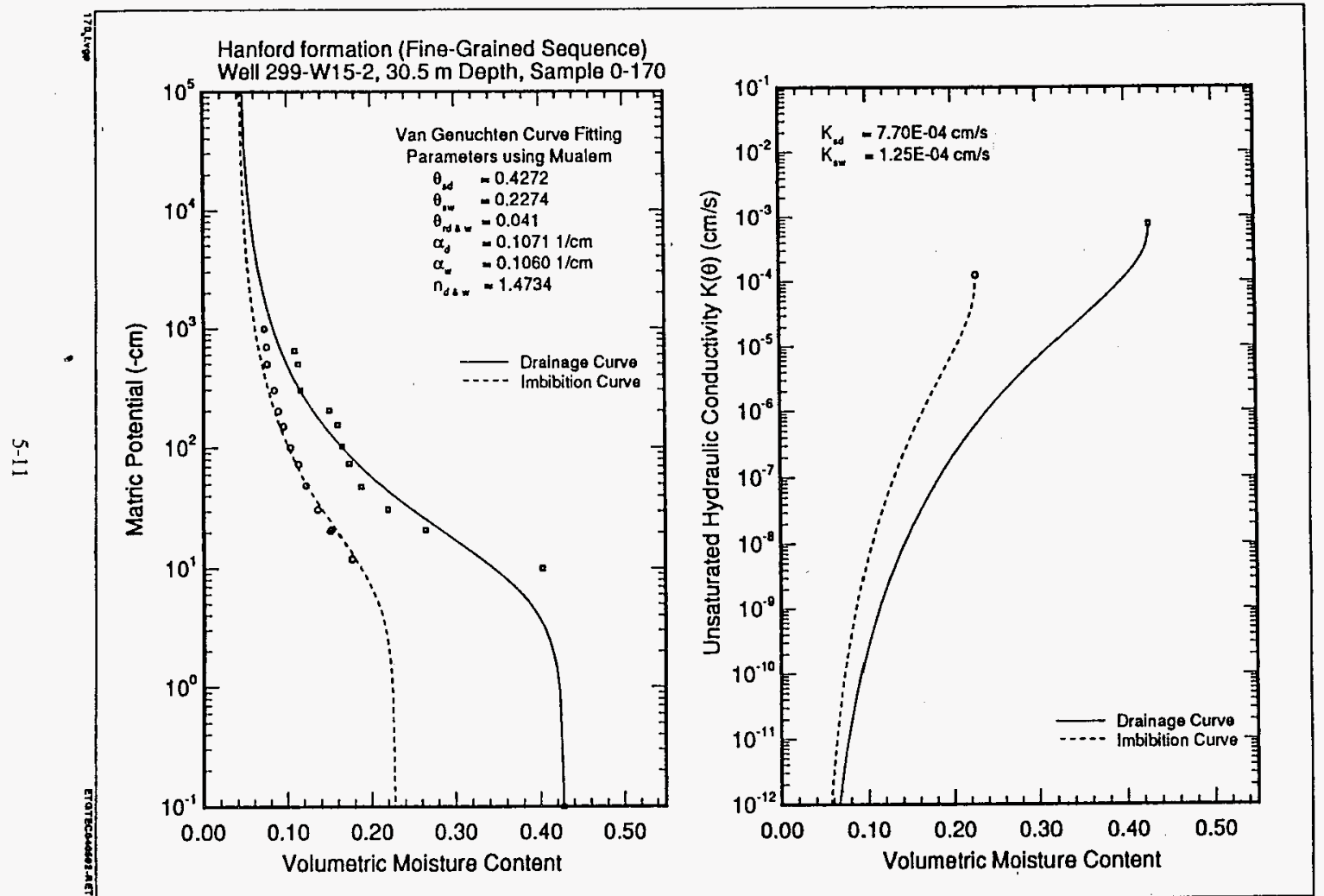

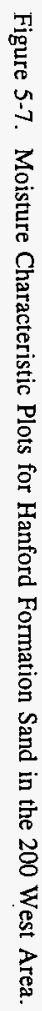

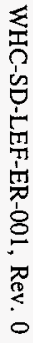




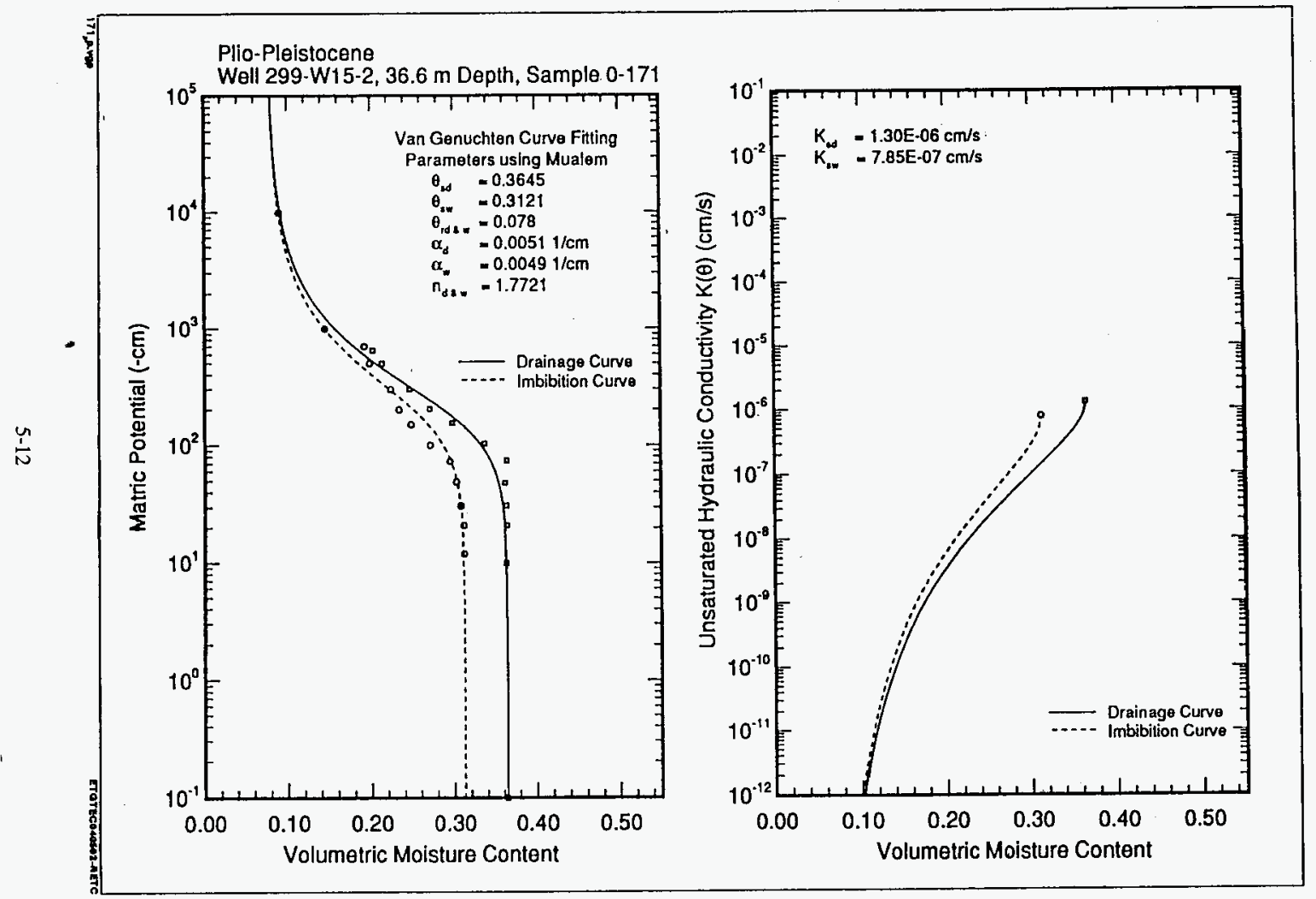

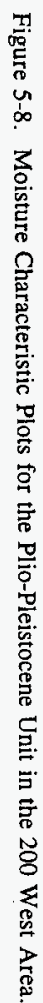

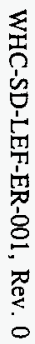


Figure 5-9. Moisture Characteristic Plots for the Ringold Formation Unit E in the 200 West Area.

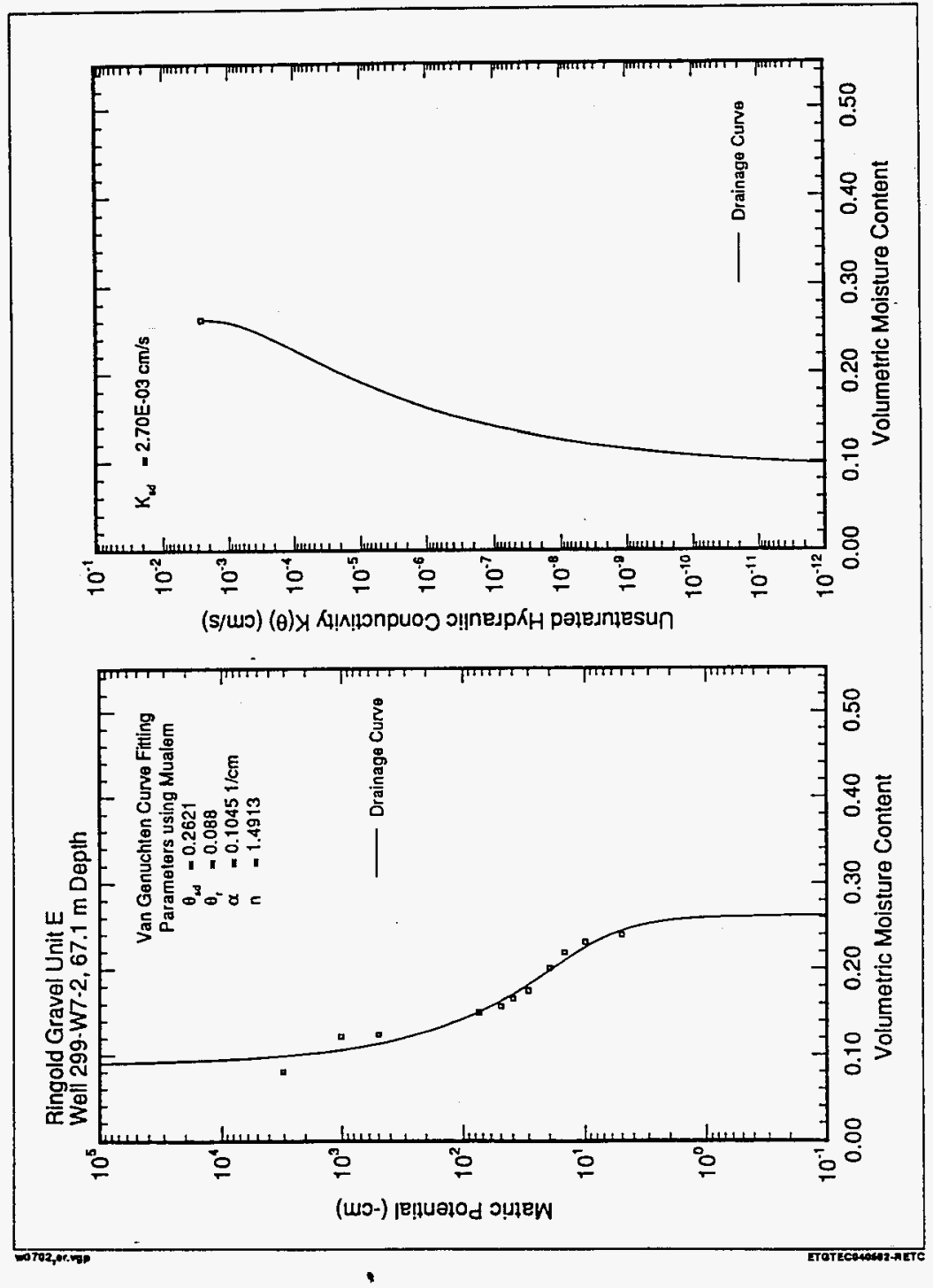




\subsubsection{Boundary Conditions}

The sides of the model domains were treated as zero-flux boundaries. The left boundary represented the centerline of the facility; by symmetry, no flux occurred across it. The right boundary was located sufficiently far from the facility that the discharge would not affect it. The appropriateness of the boundary condition for the right side was verified for each model by exarnining the results to ensure that no effects (e.g., an increase in saturation) were seen at that boundary.

The boundary condition at the base of the model was assigned a pressure head of zero. Because this boundary represented an elevation of zero, the hydraulic head at the base was also zero.

The boundary condition for the upper surface of the model was set to a flux of $5 \mathrm{~cm} / \mathrm{yr}$ $(1.97 \mathrm{in} / \mathrm{yr})$. This value was used to represent high natural recharge conditions observed at sites with disturbed vegetation and soils. Fayer and Walters (1995) report recharge rates as high as $-1 \mathrm{~cm} / \mathrm{yr}$ $(\sim 0.4 \mathrm{in} / \mathrm{yr})$ for undisturbed soils. For disturbed soils they suggest a value of $5.54 \mathrm{~cm} / \mathrm{yr}$ ( $2.18 \mathrm{in} / \mathrm{yr})$, but state that the estimate is highly uncertain.

The upper boundary condition was adjusted to simulate the operation of the facility (i.e., the 216-W-LWC and 216-S-20 cribs). The assigned flux was determined by assuming a uniform distribution of the effluent discharge over the surface area of the facility and a uniform distribution over time; i.e., the total discharge volume was divided by the surface discharge area of the facility and the duration of operations. (For purposes of modeling, the two parallel structures that comprise the 216-W-LWC Crib were combined.) The portion of the upper boundary representing the facility was assigned the calculated flux boundary condition for a duration equal to that of facility operation. After the end of simulated operation, the condition for the upper boundary of the facility was restored to a flux of $5 \mathrm{~cm} / \mathrm{yr}(1.97 \mathrm{in} / \mathrm{yr}$ ) (representing natural recharge conditions).

\subsubsection{Initial Conditions}

The initial conditions were the pressures that corresponded to a flux of $5 \mathrm{~cm} / \mathrm{yr}(1.97 \mathrm{in} / \mathrm{yr})$. Assuming unit hydraulic-gradient conditions, pressure estimates were obtained from the moisture retention curves and used as input for the model. Because this set of pressures did not constitute an exact state of equilibrium, the model used the natural recharge boundary conditions until a steadystate condition was achieved. These equilibrated initial conditions were then used as the preexisting state, upon which the effects of facility operations were superposed.

\section{$5.2 \quad 200$ EAST AREA}

Nine past-practice discharges were of interest in the 200 East Area because of their proximity to stream discharges. These discharges include eight near the PUREX Plant and one near B Plant (see Table 3-2). 


\subsubsection{Sources}

As was the case for the 200 West Area facilities, each of the eight past-practice discharges of interest near the PUREX Plant and the one past-practice discharge near B Plant in the 200 East Area were evaluated with respect to total volume of effluent discharged, average discharge rate, and vertical flux density.

The total volume of effluent discharged to each facility of interest in the 200 East Area is shown in Figure 5-10. The rate of discharge to each facility, calculated by dividing the volume of discharge by the duration of facility operation, is shown in Figure 5-11. The flux density is shown in Figure 5-12. A representative miscellaneous stream discharge is shown in each of the three figures for purposes of comparison.

As noted in Figures 5-10 through 5-12, the nine facilities generally can be characterized in terms of three broad groupings according to relative volumes of discharge. The figures depicting the discharge rates and flux densities confirm these three groupings. The A36A, A2, and A31 facilities are in a relatively low-volume discharge group. The A21, A27, and A4 facilities are in a mediumvolume discharge group. The $\mathrm{A} 5, \mathrm{~A} 10$, and $\mathrm{B} 10 \mathrm{~A}, \mathrm{~B}$ facilities are in a relatively high-volume discharge group.

As was the case for the 200 West Area, the highest discharge-volume facility in each of the three groups was generally considered to represent all lower-volume discharge facilities in that group. The A21 facility was chosen to represent facilities with medium-volume discharges, A36A to represent facilities with relatively low-volume discharges, and A5 to represent facilities with relatively high-volume discharges.

\subsubsection{Model Geometry}

With the exception of one discharge in the vicinity of B Plant, most of the current miscellaneous stream discharges in the 200 East Area are in the vicinity of the PUREX Plant (see Figure 3-9). Consequently, the stratigraphy of the 200 East Area was depicted for purposes of modeling by inspecting numerous well $\operatorname{logs}$ and cross sections in the vicinity of the PUREX and B Plants. From these well logs, a well log (299-E24-16) judged as representative was selected. The stratigraphy portrayed by the model was shown in Figure 4-4 and consists of the following three horizontal strata:

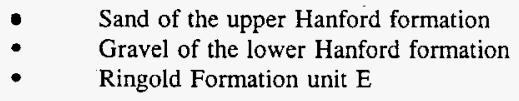

from 0 to $190 \mathrm{ft}$ (190 ft thick) from 190 to $275 \mathrm{ft}(85 \mathrm{ft}$ thick) from 275 to $315 \mathrm{ft}$ ( $40 \mathrm{ft}$ thick).

The gravel of the Hanford formation includes gravelly sand and sandy gravel. For purposes of this analysis, the Ringold unit $\mathrm{E}$ includes lithologies of Ringold unit A gravel and the Ringold lower mud sequence.

Figure 5-13 depicts the mesh used to discretize the model domain for analysis of pastpractice discharges to the facilities of interest in the 200 East Area. A cluster of closely-spaced vertical lines is located near the left edge of the figure and is a refinement of the mesh in an area with a high contrast in boundary conditions - from the crib discharging on one side of the boundary to natural recharge conditions on the other side. 
Figure 5-10. Discharge Volumes for the 200 East Area Facilities.

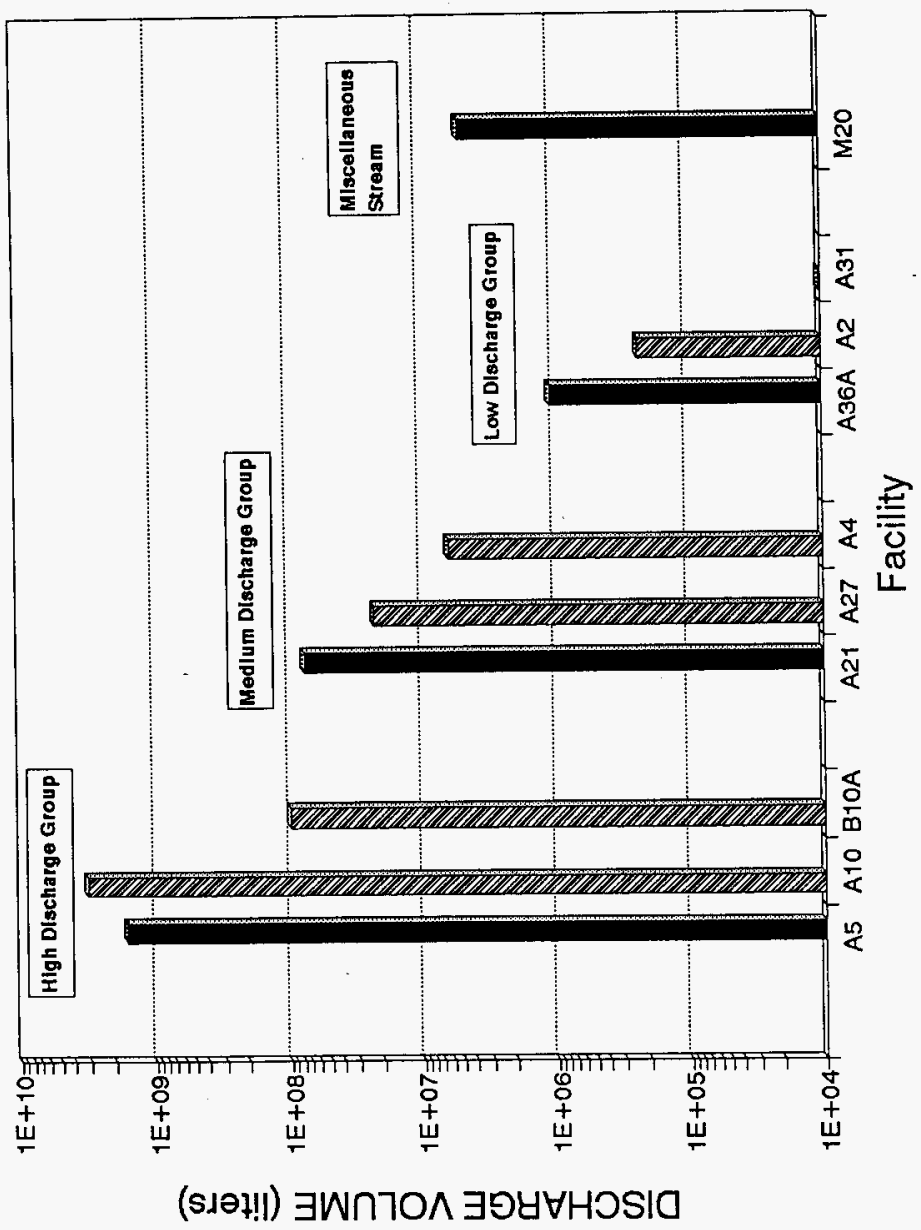


WHC-SD-LEF-ER-001, Rev. 0

Figure 5-11. Discharge Rates for the 200 East Area Facilities.

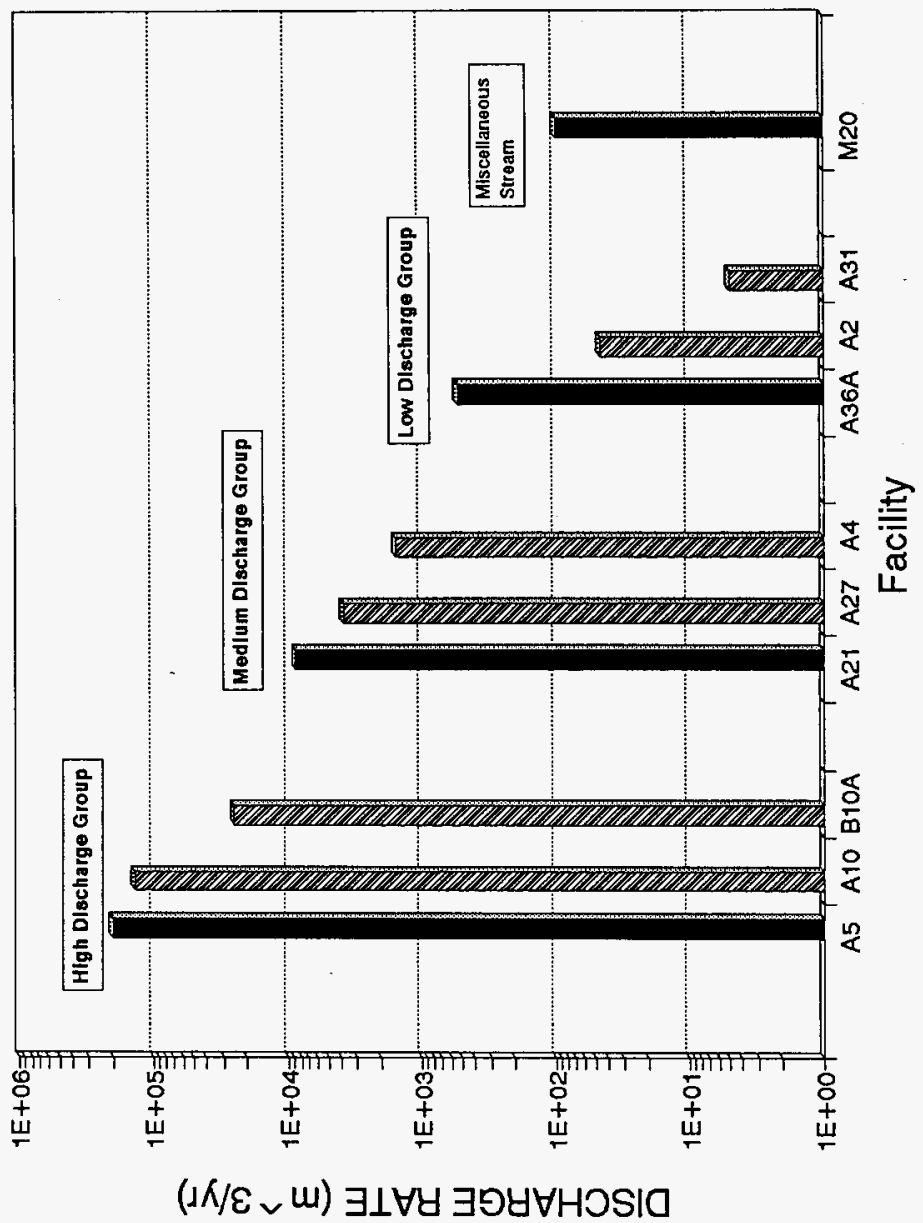


WHC-SD-LEF-ER-001, Rev. 0

Figure 5-12. Flux Densities for the 200 East Area Facilities.

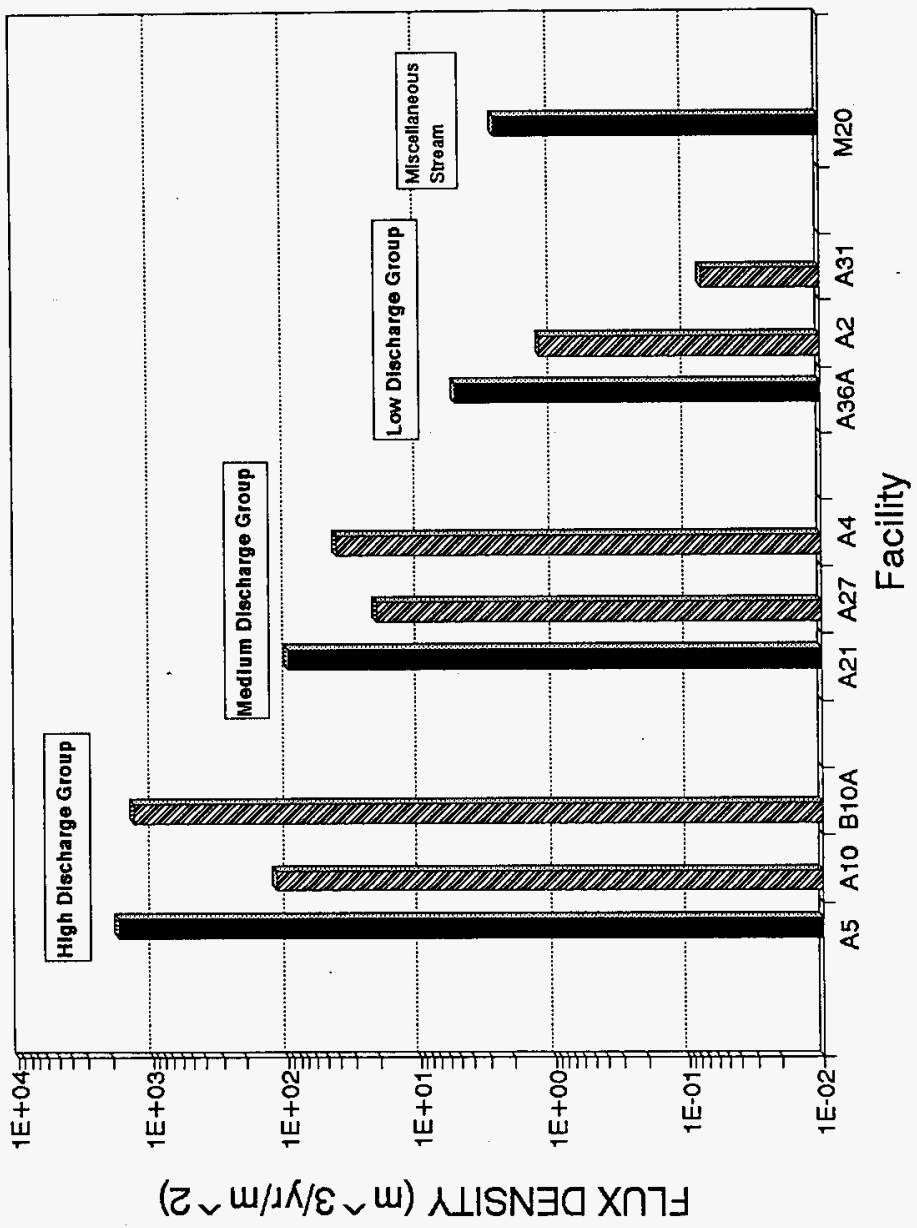




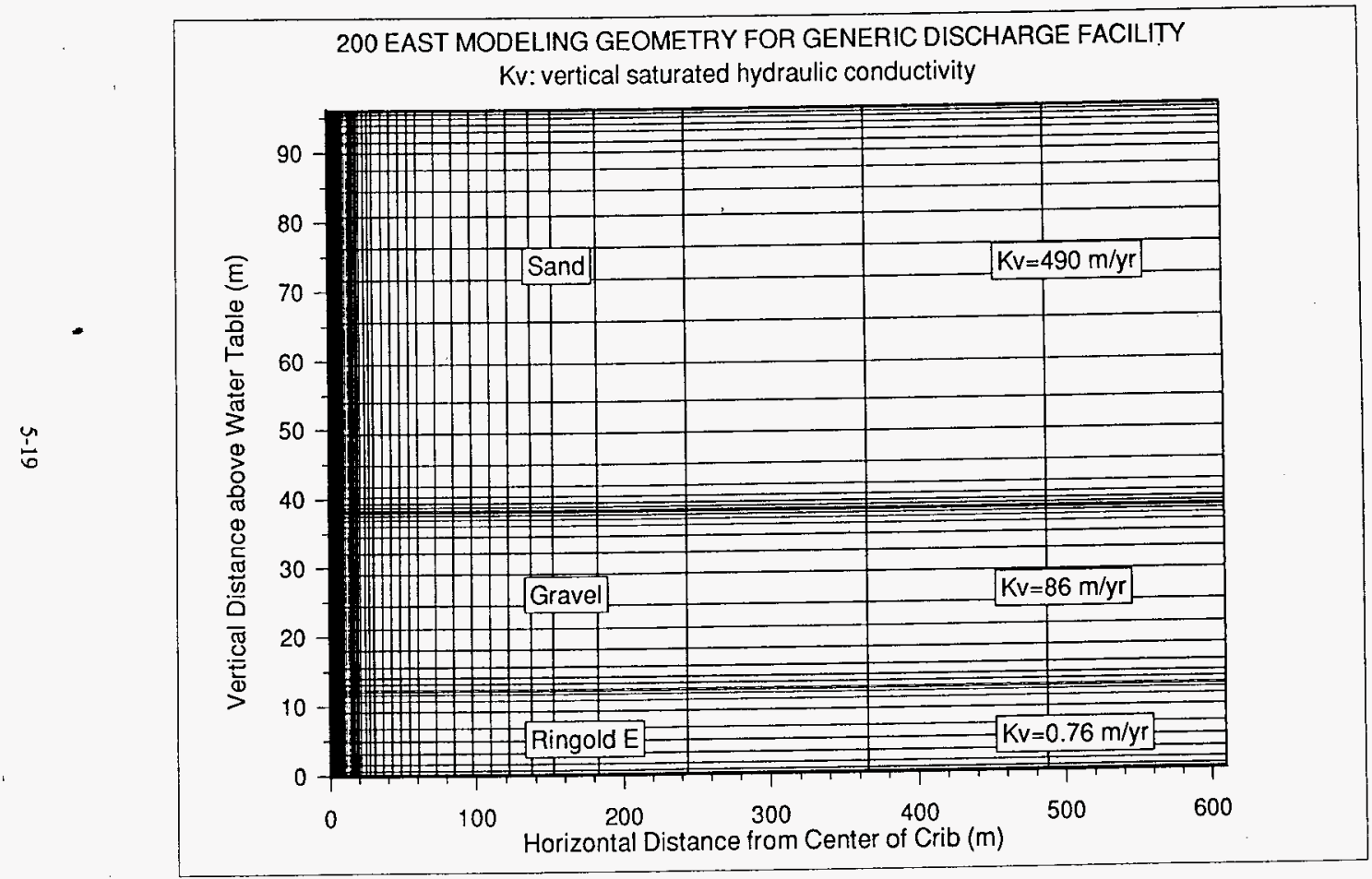


Horizontal lines at the lithologic unit interfaces are closely spaced to represent high contrasts in hydraulic properties at the contacts between different lithologies. Closely-spaced horizontal lines at the top of the spatial domain are refinements needed to simulate the rapid introduction of large volumes of effluent into relatively dry sediments. Closely spaced lines at the bottom of the spatial domain are refinements needed to simulate the transition from relatively dry strata in the vadose zone to saturated conditions in the uppermost aquifer.

Figure 5-13 also identifies the saturated vertical hydraulic conductivities of the three lithologies that were modeled to illustrate their variability. (For unsaturated conditions, the hydraulic conductivities can vary by orders of magnitude.) The contrasts for unsaturated conditions are normally depicted in plots of van Genuchten curve parameters. No curves are available for the 200 East Area parameters because the conductivity values are averages, but the contrasts are similar to those seen for the 200 West Area sediments (see Figures 5-5 and 5-7 through 5-9).

A separate mesh was generated for the model of the miscellaneous waste stream.

The horizontal mesh lines remained the same for all models. The number and location of vertical mesh lines were adjusted to minimize the size of the model, while simultaneously providing adequate coverage of the modeling domain.

\subsubsection{Hydraulic Properties}

The soil hydraulic properties used to represent the 200 East Area were from Performance Assessment of Grouted Double-Shell Tank Waste Disposal at Hanford (Kincaid et al. 1994). The data reported by Kincaid et al. (1994), which are used without change or alteration for this report, are shown in Table 5-3.

Table 5-3. Hydraulic Properties Used as Input Values for the 200 East Area Sediments (After Kincaid et al. 1994).

\begin{tabular}{|c|c|c|c|c|c|}
\hline Sediment Type & $\begin{array}{c}\text { Saturated } \\
\text { Hydraulic } \\
\text { Conductivity } \\
(\mathrm{m} / \mathrm{yr}) \\
\end{array}$ & $\begin{array}{l}\text { Effective } \\
\text { Porosity } \\
\text { (cc/cc) }\end{array}$ & $\begin{array}{l}\text { Residual } \\
\text { Moisture } \\
\text { Content } \\
\text { (cc/cc) }\end{array}$ & $\begin{array}{c}\text { van Genuchten } \\
\text { parameters: alpha } \\
\left(\mathrm{cm}^{-1}\right) ; n \\
\text { (unitless) }\end{array}$ & $\begin{array}{c}\text { Dry Bulk } \\
\text { Density } \\
\text { (g/cc) }\end{array}$ \\
\hline Hanford sand & $\begin{array}{r}\text { V } 488.8 \\
\text { H } 4888.0\end{array}$ & .4203 & .023 & $\begin{array}{c}.1943 \\
1.868\end{array}$ & 1.68 \\
\hline Hanford gravel & $\begin{array}{ll}\text { V } & 86.093 \\
\text { H } & 860.93\end{array}$ & .3584 & .021 & $\begin{array}{l}.0290 \\
1.613\end{array}$ & 1.73 \\
\hline $\begin{array}{l}\text { Ringold } \\
\text { unit } E\end{array}$ & $\begin{array}{cc}\mathrm{V} & 0.763 \\
\mathrm{H} & 7.362\end{array}$ & .4982 & .028 & $\begin{array}{l}0.0176 \\
1.338\end{array}$ & 1.45 \\
\hline
\end{tabular}

$\mathrm{V}=$ vertical; $\mathrm{H}=$ horizontal

\section{$\underline{\text { Hanford Sand }}$}

Hydraulic properties of the Hanford sand in the areas of interest for the 200 East Area were represented by average values developed from several data sets. These data include 28 sets of parameter values from well 299-E-234 on the west edge of the Grout Treatment Facility, five sets from the 241-AP Tank Farm excavation, 21 sets from the U.S. Ecology solid waste burial site, three 
sets from the 200-BP-1 site, and three values of in situ saturated hydraulic conductivity from a borehole permeameter in the bottom of the Grout Treatment Facility excavation.

\section{Hanford Lower Gravel}

Hydraulic properties used in the model for the Hanford lower gravel were averages based on two sets of parameter values from well 299-E25-234, eight sets of data from the 200-BP-1 site, two sets of data from the 241-B Pond, and two sets of data from the U.S. Ecology site. Some parameter values were from samples of the upper gravel sequence of the Hanford formation. However, the upper and lower gravel sequences of the Hanford formation were judged by Kincaid et al. (1994) to be texturally similar and essentially indistinguishable except by stratigraphic position.

\section{Ringold Formation}

Hydraulic properties used in the model for the Ringold unit $E$ were based on the averages from four sets of parameter values for samples taken from the Ringold Formation (undifferentiated) near the 241-B Pond and one set from the U.S. Ecology site.

\subsubsection{Boundary Conditions}

The boundary conditions for the 200 East Area were the same as for the 200 West Area (see Section 5.1.4), except for the upper boundary of the model. Because of the hydraulic behavior of the Hanford sand, it was determined that applying a constant pressure at the upper boundary produced more consistent results for the natural recharge state. The vertical velocities and moisture contents for the uppermost cells of the model were more accurate when prescribing pressure denominated boundary conditions, than when prescribing constant fluxes. The portion of the upper boundary representing the facility was assigned flux boundary conditions in the same manner as for the 200 West Area; i.e., by specifying operational fluxes for the duration of facility discharge.

\subsubsection{Initial Conditions}

The initial conditions were determined by the same means as for the 200 West Area (see Section 5.1.5). The model was run using the natural recharge boundary conditions until steady-state conditions were observed.

\section{$5.3 \quad 300$ AREA}

One past-practice discharge was of interest in the 300 Area because of its proximity to stream discharges. These stream discharges occur near the 316-3 Trenches (see Table 3-2). 


\subsubsection{Sources}

The single past-practice discharge of interest was evaluated with respect to total volume of effluent discharged, average discharge rate, and vertical flux density. The total volume of effluent discharged to the facility of interest in the 300 Area is shown in Figure 5-14. The rate of discharge to the facility, considering the volume of discharge and duration of facility operation, is shown in Figure 5-15. The flux density is shown in Figure 5-16. A representative miscellaneous stream discharge is shown in each figure for comparison.

\subsubsection{Model Geometry}

The stratigraphy used for the 300 Area model was based on the composite section shown in Figure 4-5. The stratigraphy consists of two horizontal strata:

- Hanford gravel from 0 to $40.4 \mathrm{ft}(40.4 \mathrm{ft}$ thick)

- Eolian sand from 40.4 to $50.4 \mathrm{ft}$ (10.0 ft thick).

Figure 5-17 illustrates the mesh representing the spatial discretization of the modeling domain used to analyze past-practice discharges to the 316-3 Trenches. The spacing between vertical lines is narrow near the center of the trenches and near the edge of the trenches. This refinement is needed because of the high contrasts in boundary conditions that occur in these areas -- from the high artificial recharge conditions in the trench to natural recharge conditions surrounding the trenches.

The narrow spacing between horizontal lines near the top of the spatial domain is needed to simulate the rapid introduction of large volumes of water into relatively dry sediments. Narrowly spaced horizontal lines are needed at the interface between the lithologic units to represent the high contrast in hydraulic properties between the different stratigraphic units. Narrowly spaced horizontal lines are present at the bottom of the spatial domain to simulate the transition from relatively dry strata in the vadose zone to saturated sediments in the uppermost aquifer.

Figure 5-17 also illustrates the differences between the saturated vertical hydraulic conductivities of the two lithologies that were modeled (separated by a thick, dashed line in the figure). For unsaturated conditions, the contact between hydraulic conductivities can vary by even more orders of magnitude.

\subsubsection{Hydraulic Properties}

Data available for samples of sediments retrieved from locations near the Columbia River were reviewed to select the best available data for soil hydraulic properties. Only samples from near the river were considered, because they were judged to be more representative of depositional processes and sediments in the area of interest than samples from the 200 Area plateau.

The hydraulic properties of these sediments were measured at the Hanford Geotechnical Engineering Laboratory (HGEL) and at Southwest Research Institute. The applicable HGEL measurements are provided in Appendix A. The Southwest Research Institute measurements were reported by Lockheed Martin (Lockheed Martin 1996). 
WHC-SD-LEF-ER-001, Rev. 0

Figure 5-14. Discharge Volumes for the 300 Area Facility.

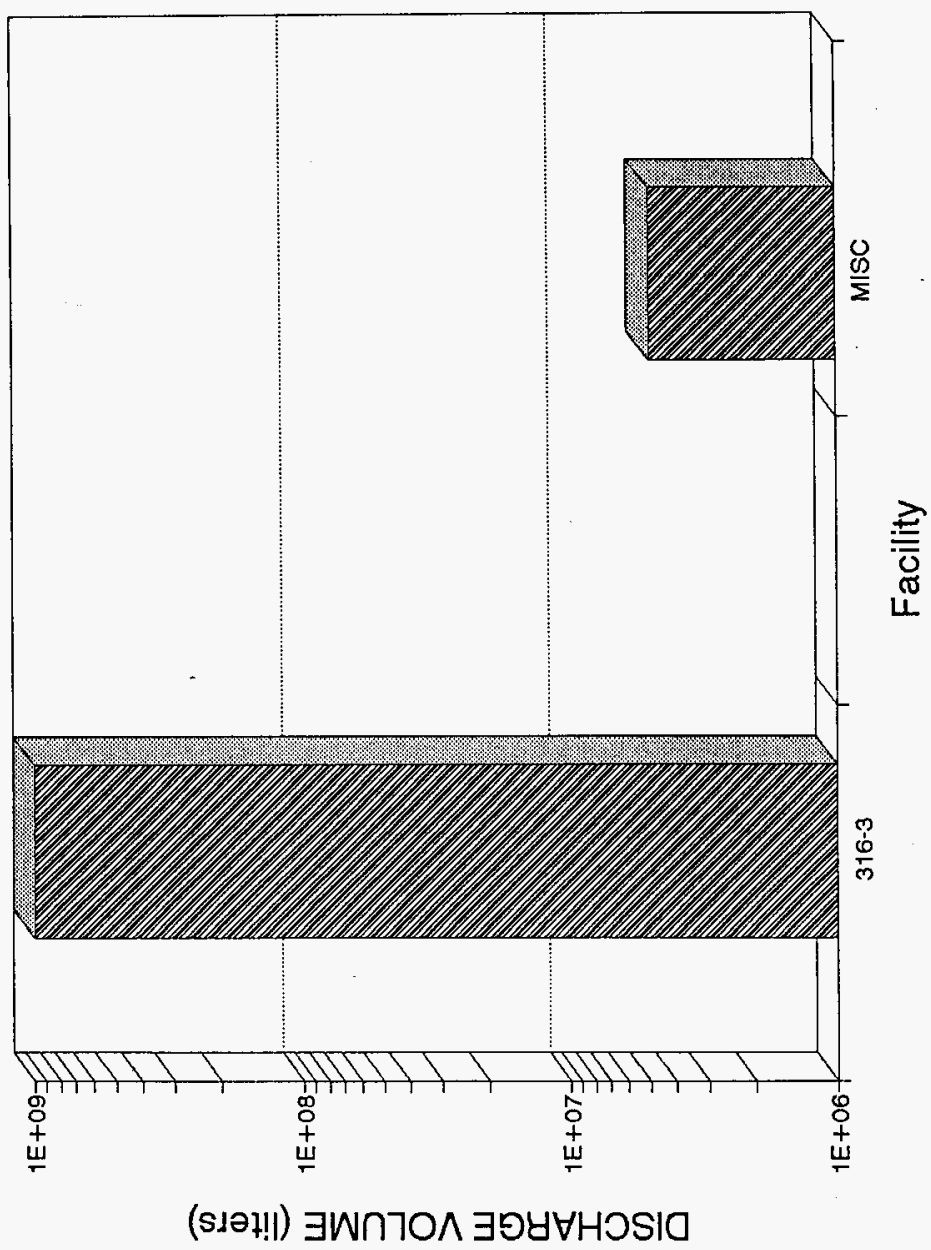


WHC-SD-LEF-ER-001, Rev. 0

Figure 5-15. Discharge Rates for the 300 Area Facility.

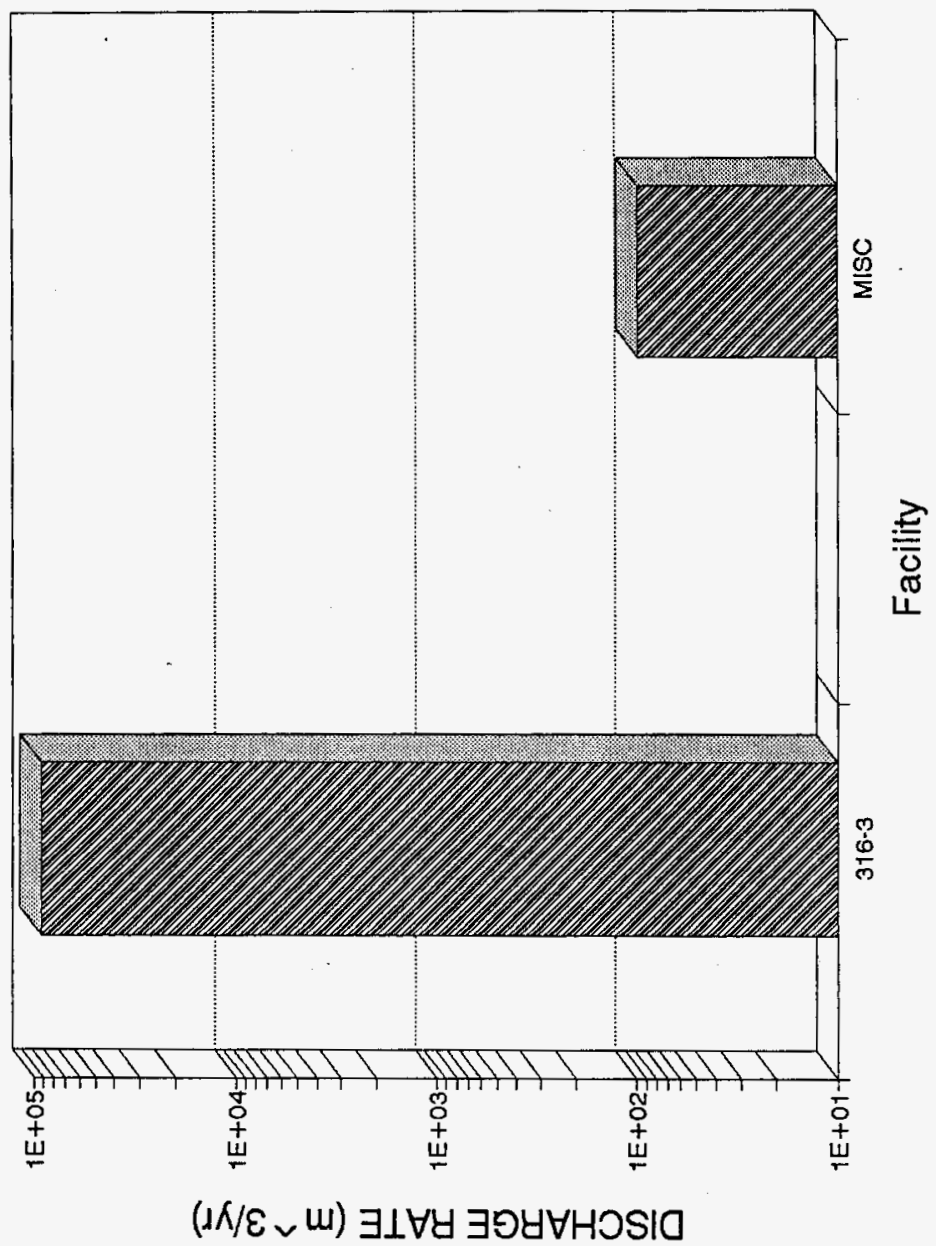


WHC-SD-LEF-ER-001, Rev. 0

Figure 5-16. Flux Densities for the 300 Area Facility.

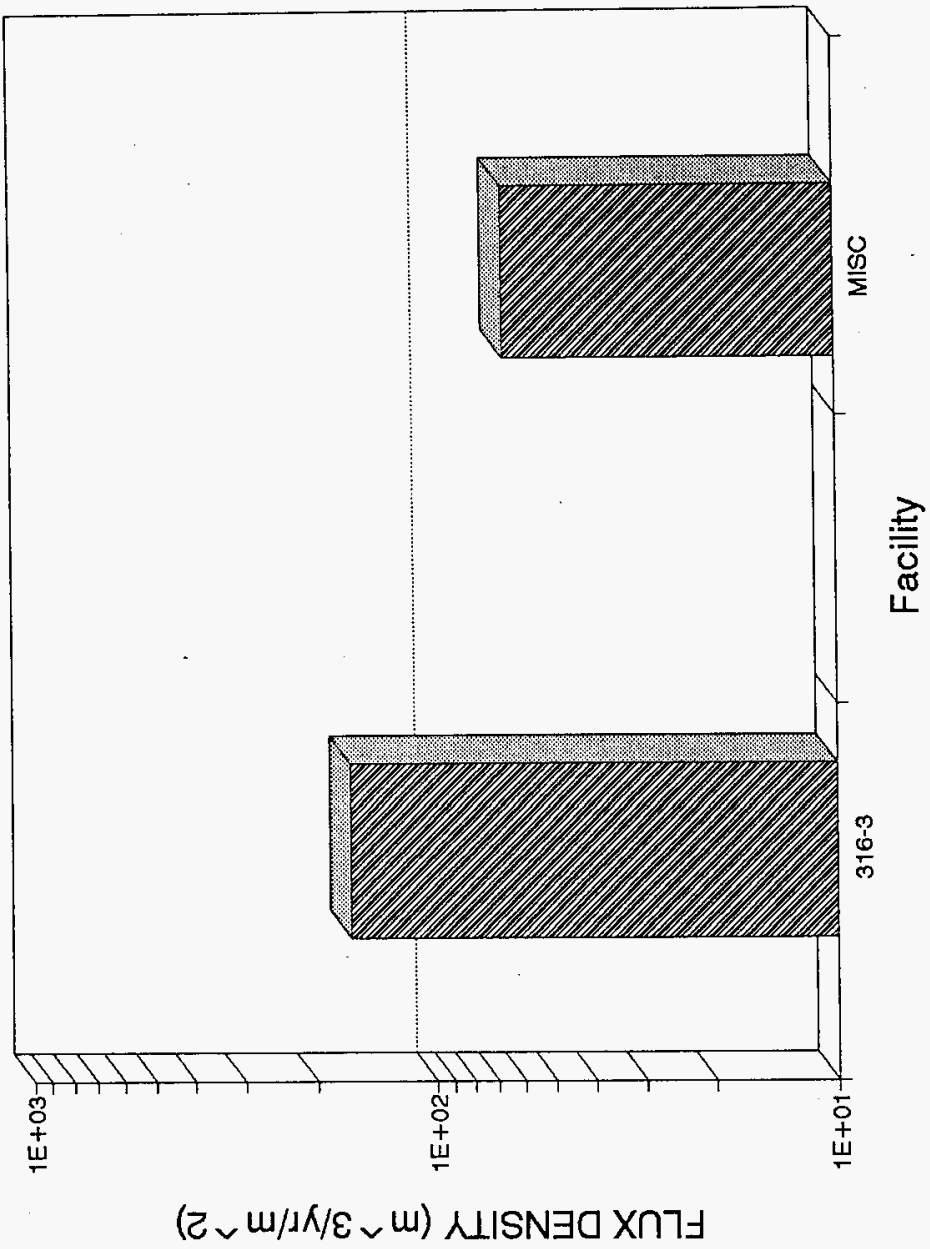




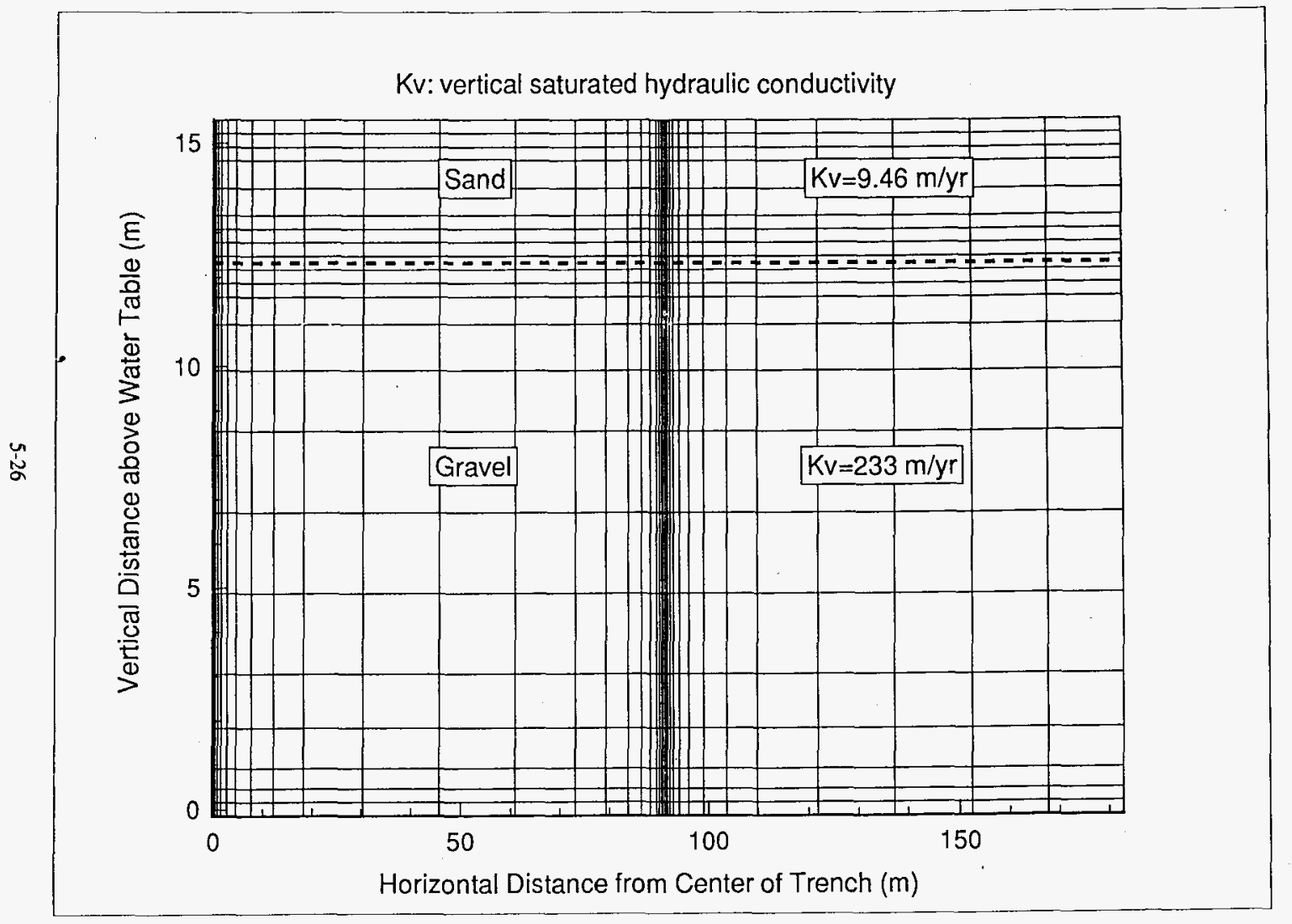

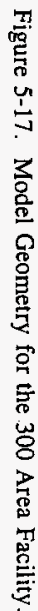


Samples BOGL74 and BOGL85 (Appendix A), respectively, were selected to represent the sand and gravel units shown in Figure $4-5 ; 96.5 \%$ of the sand sample (by weight) passed the \#10 sieve; $5.0 \%$ of the gravel sample (by weight) passed the $\# 10$ sieve.

The van Genuchten parameters for these samples were calculated and are listed in Table 5-4. Table 5-4 also includes other key hydraulic properties for the sand and gravel units.

Table 5-4. Soil Hydraulic Properties Used as Input Values for the 300 Area Sediments.

\begin{tabular}{||c|c|c|c|c|c|}
\hline Sediment Type & $\begin{array}{c}\text { Saturated } \\
\text { Hydraulic } \\
\text { Conductivity } \\
\text { (m/yr) }\end{array}$ & $\begin{array}{c}\text { Effective } \\
\text { Porosity } \\
(\mathrm{cc} / \mathrm{cc})\end{array}$ & $\begin{array}{c}\text { Residual } \\
\text { Moisture } \\
\text { Content } \\
(\mathrm{cc} / \mathrm{cc})\end{array}$ & $\begin{array}{c}\text { van Genuchten } \\
\text { parameters: alpha } \\
\left(\mathrm{cm}^{-1}\right) ; \mathrm{n} \\
(\text { unitless })\end{array}$ & $\begin{array}{c}\text { Dry Bulk } \\
\text { Density } \\
(\mathrm{g} / \mathrm{cc})\end{array}$ \\
\hline Hanford sand & $\begin{array}{r}\mathrm{V} 9.46 \\
\mathrm{H} 94.6\end{array}$ & .346 & 0 & $\begin{array}{l}0.0081 \\
1.4477\end{array}$ & 1.76 \\
\hline Hanford gravel & $\mathrm{V} 233$. & .2084 & 0 & $\begin{array}{l}0.0024 \\
1.7207\end{array}$ & 1.96 \\
\hline
\end{tabular}

$\mathrm{V}=$ vertical; $\mathrm{H}=$ horizontal

\section{Harford Sand}

Hydraulic properties of the sand unit were represented by a sample collected from well 199-N-108A at a depth of $24 \mathrm{ft}(7 \mathrm{~m})$. The overall curve fit for the van Genuchten parameters was judged to be acceptable (Figure 5-18), with the poorest fit being for the dry portion of the curve. The vertical saturated hydraulic conductivity of $3 \mathrm{E}-5 \mathrm{~cm} / \mathrm{sec}$ is at the low end of the range expected for sands.

Because moisture retention measurements were made only on material that passed the $\# 10$ sieve, gravel corrections were required. After making the appropriate gravel corrections, the corrected effective porosities were checked against the total porosity for the unsieved sample. The sand sample, BOGL74 (Appendix A), had a corrected effective porosity of about $49 \%$ and a field total porosity of about $35 \%$. Because the effective porosity was substantially larger than the total porosity, all volumetric moisture data were multiplied by a factor of $0.71(.35 / .49)$.

\section{Hanford Gravel}

Hydraulic properties of the gravel unit were represented by a sample collected from well $199-\mathrm{N}-108 \mathrm{~A}$ at a depth of $63 \mathrm{ft}(19 \mathrm{~m})$. The overall curve fit for the van Genuchten parameters was judged to be acceptable (Figure 5-19). The vertical saturated hydraulic conductivity of $7.4 \mathrm{E}-4 \mathrm{~cm} / \mathrm{sec}$ is within the range expected for a sandy gravel ( $50.8 \%$ gravel by weight).

After making the appropriate gravel corrections, the adjusted effective porosity was checked against the total porosity for the unsieved sample. The gravel sample, BOGL85, had a corrected effective porosity of about $23 \%$ and a field total porosity of about $28 \%$. Because the effective porosity was appropriately smaller than the total porosity, no further adjustments were required. 
Figure 5-18. Moisture Characteristic Plots for Sand in the 300 Area.

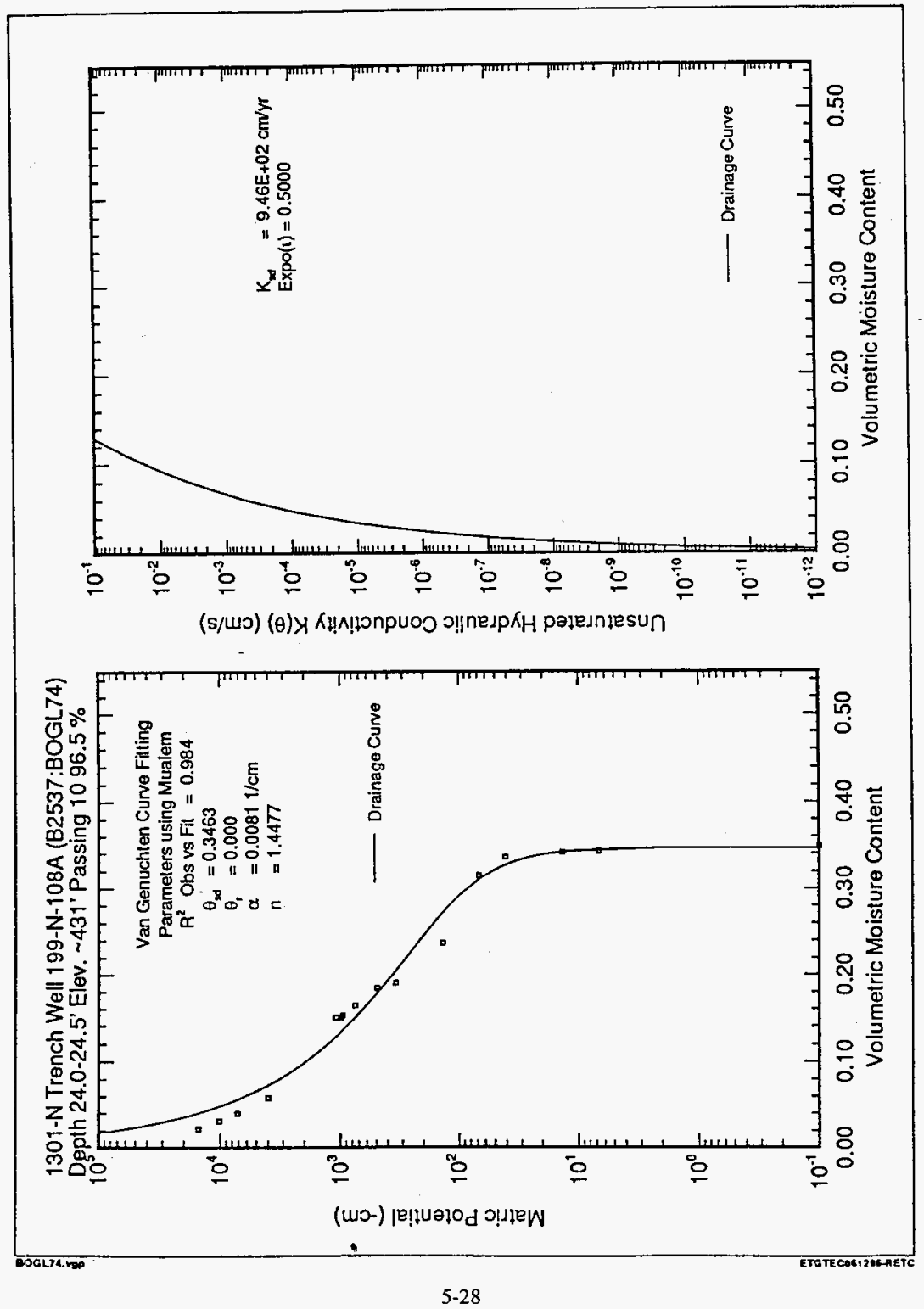


Figure 5-19. Moisture Characteristic Plots for Sand in the 300 Area.

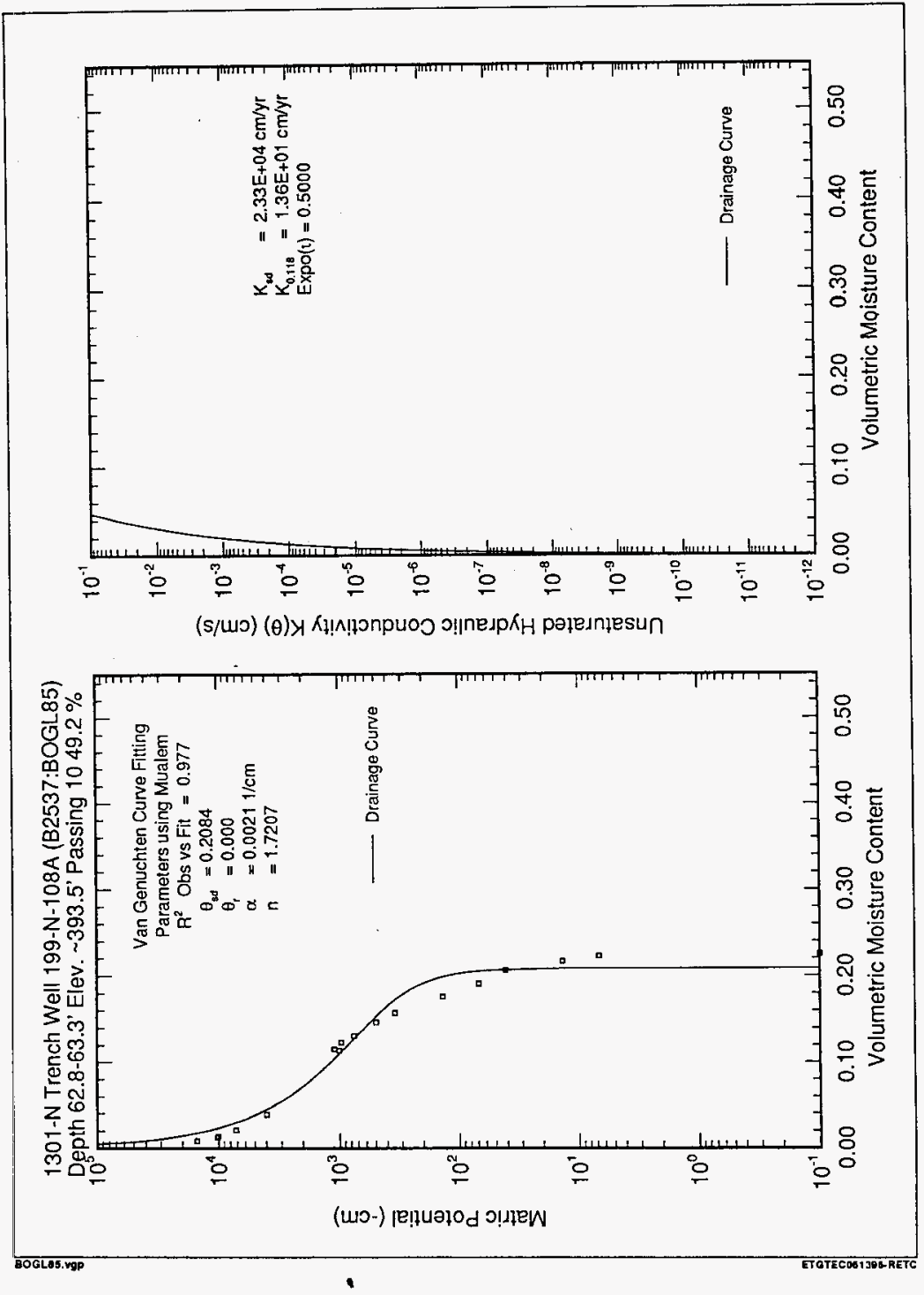




\subsubsection{Boundary Conditions}

The boundary conditions for the 300 Area were the same as for the 200 West Area (see Section 5.1.4), except for the upper boundary of the model. The portion of the upper boundary representing the facility was assigned flux boundary conditions in the same manner as for the 200 West Area; i.e., by specifying operational fluxes for the duration of the facility discharge.

\subsubsection{Initial Conditions}

The initial conditions were determined by the same means as for the 200 West Area (see Section 5.1.5). The simulations were made using the natural recharge boundary conditions until steady-state conditions were observed. 
WHC-SD-LEF-ER-001, Rev. 0

\subsection{MOISTURE PROFILE RESULTS}

\subsection{WEST AREA}

The 200 West Area model was developed using a highly conservative assumption of laterally continuous caliche to represent the Plio-Pleistocene unit. The representative of each facility group was analyzed using this assumption. After examining preliminary modeling results and after further researching the characteristics of the Plio-Pleistocene, it was determined that a less conservative, more representative model would be more appropriate for the facilities represented by the $216-\mathrm{W}-\mathrm{LWC}$ Crib.

The revised model assumed that the caliche in the Plio-Pleistocene unit was $90 \%$ continuous (see Section 4.3 for discussion of the caliche) beyond the outermost edge of the facility. The discontinuities were simulated by introducing a $10-\mathrm{ft}$-wide vertical gap in the caliche after a distance of 90 horizontal feet in which caliche was assumed to be continuously present. The discontinuity was assumed to be infilled with sand from the overlying Hanford formation. The caliche directly beneath the facility was assumed to be continuous. Consequently, the first discontinuity was located $27 \mathrm{~m}(90 \mathrm{ft}$ ) beyond the edge of the facility located at $45.67 \mathrm{~m}$ (150 ft) from the center. Three discontinuities were simulated. Hence, the outer edge of the most distant discontinuity in the caliche was $92 \mathrm{~m}(300 \mathrm{ft})$ from the edge of the facility.

The steady-state moisture profile representing in situ conditions at the start of operations for the simulated 216-W-LWC Crib is shown in Figure 6-1. The same information for the 216-S-20 Crib is shown in Figure 6-2. Effective saturation contours are closely spaced at sediment interfaces and near the water table (and, in some instances, appear as a single thick contour in the figure). In Figure 6-1, the contours are closely spaced at the simulated discontinuities in the Plio-Pleistocene unit. For relatively dry conditions, such as for natural recharge, the simulated discontinuities inhibit flow. For relatively wet conditions, such as during operation of the high-discharge facilities, the discontinuities become flow paths.

The series of horizontally aligned solid black boxes identify sediment interfaces. Only some of these boxes are shown to allow a clearer view of the rest of the figure.

\subsubsection{6-W-LWC Crib}

The maximum lateral distance at which an increase in effective saturation is predicted is $-156 \mathrm{~m}(-512 \mathrm{ft}$ ) (Figure 6-3). This increase is seen in the Plio-Pleistocene unit after 8 years of operations. The edge of the facility depicted in the figure is at a distance of $45.67 \mathrm{~m}(149.84 \mathrm{ft})$ from the left edge of the figure. Consequently, moisture from the facility spreads laterally $\sim 110 \mathrm{~m}$ (361 ft) from the edge of the crib. 
WHC-SD-LEF-ER-001, Rev. 0

Figure 6-1. Pre-operations Moisture Profile for the 216-W-LWC Crib.

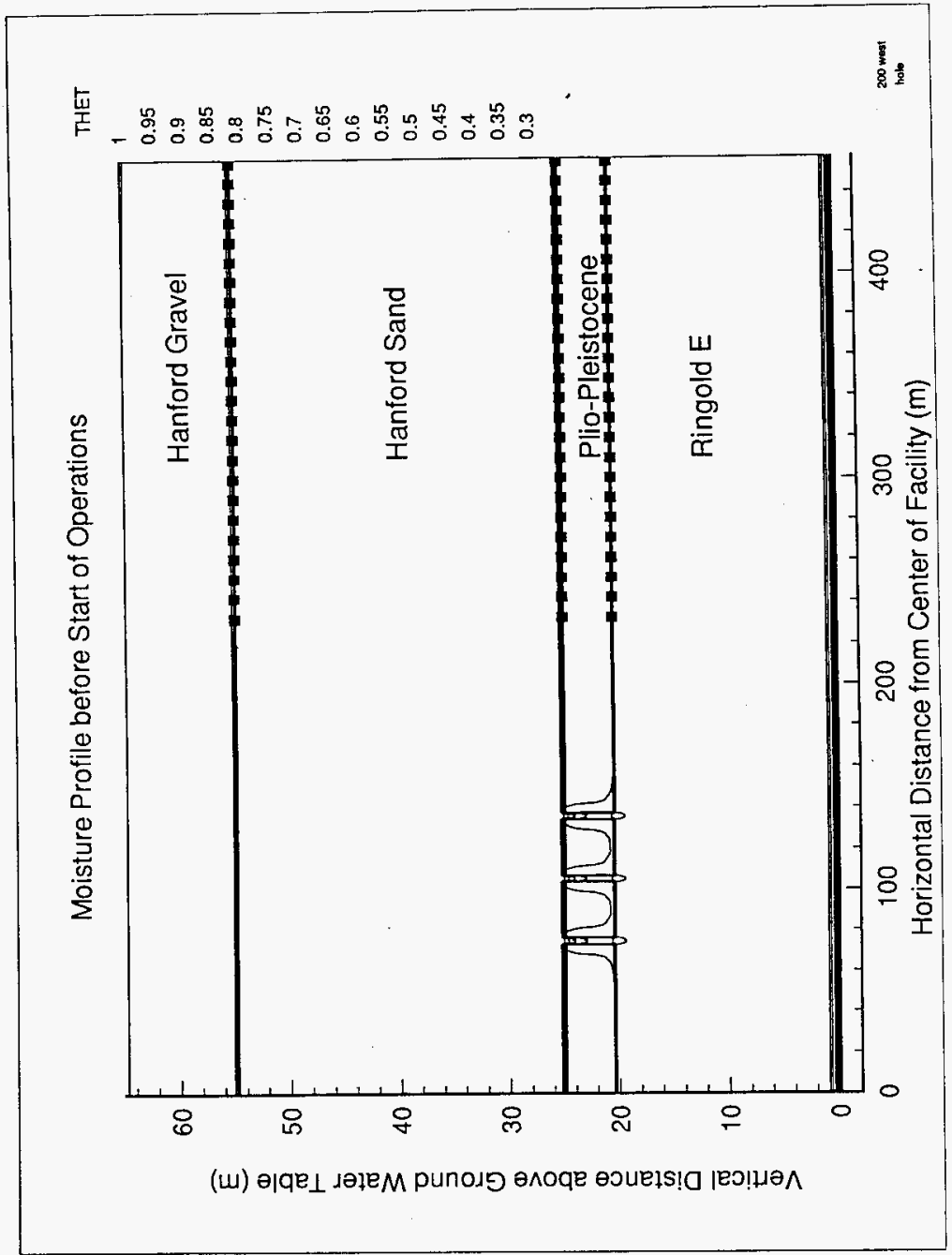




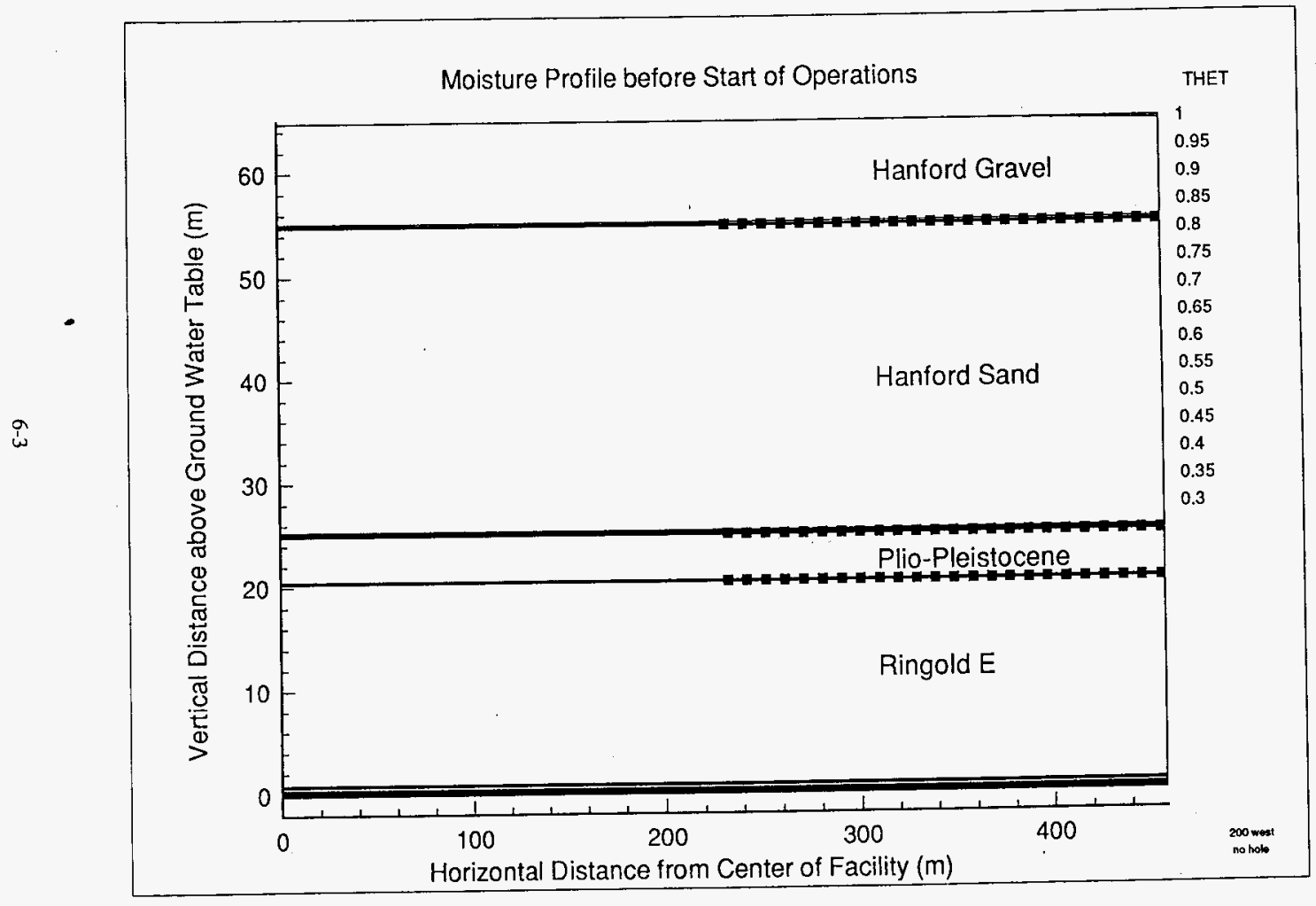

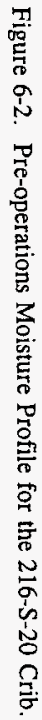


Figure 6-3. Post-operations Moisture Profile for the 216-W-LWC Crib.

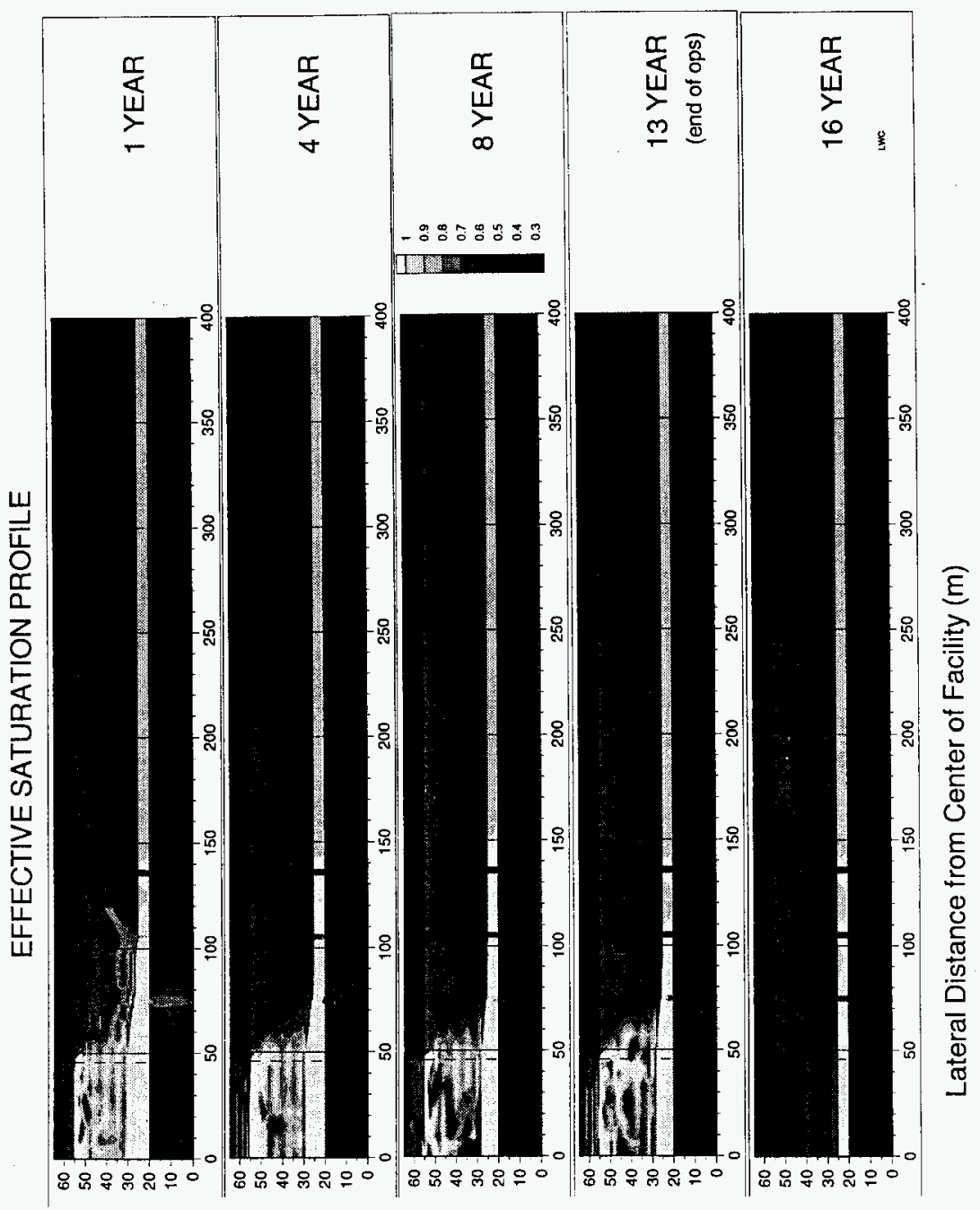

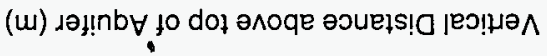




\subsubsection{6-S-20 Crib}

The 216-S-20 Crib was simulated without any discontinuities in the caliche because they were determined to have no effect at the lower-volume discharges represented by this facility. The maximum lateral distance at which an increase in effective saturation is predicted is $\sim 42 \mathrm{~m}$ $(138 \mathrm{ft}$ ) (Figure 6-4). This increase is seen in the Plio-Pleistocene unit at the end of 16 years of operations. In all lithologies except the Plio-Pleistocene unit, no lateral spreading was observed.

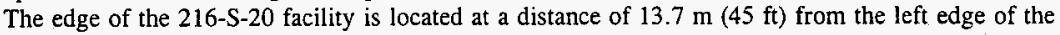
figure. Consequently, $\sim 31 \mathrm{~m}(102 \mathrm{ft})$ of lateral spreading from the edge of the facility is predicted.

\subsubsection{Miscellaneous Stream}

The miscellaneous stream was simulated for three discharge facility configurations. The first configuration was a two-dimensional vertical cross section for which discharge to a 6-m $x$ 6-m (20-ft $\mathrm{x} 20$-ft) facility was simulated. The second configuration was an axisymmetric simulation of a 6-m-diameter ( 20 -ft-diameter) discharge facility with a vertical axis of symmetry. This configuration was used to determine the degree of conservatism of the first configuration. The third configuration was an axisymmetric simulation of a 1.2-m-diameter (4-ft-diameter) discharge facility. This configuration was used to verify that the larger size of the $6.1-\mathrm{m}(20-\mathrm{ft})$ facility had negligible impact on the predicted extent of lateral spreading.

For each configuration, the maximum extent of lateral spreading of the effluent was predicted to occur in the Plio-Pleistocene unit (Figures 6-5 through 6-7). Results for each configuration are shown in Table 6-1.

Table 6-1. Lateral Spreading of Moisture for Various Miscellaneous Stream Configurations.

\begin{tabular}{|l|c|}
\hline \multicolumn{1}{|c|}{ Configuration of Infiltration Surface } & Predicted Maximum Lateral Spread of Effluent \\
\hline Two-dimensional: $6.1-\mathrm{m}(20-\mathrm{ft})$ long & $51 \mathrm{~m}(15.5 \mathrm{ft})$ \\
\hline Axisymmetric: $6.1-\mathrm{m}(20-\mathrm{ft})$ diameter & $30 \mathrm{~m}(9.1 \mathrm{ft})$ \\
\hline Axisymmetric: $1.2-\mathrm{m}(4-\mathrm{ft})$ diameter & $30 \mathrm{~m}(9.1 \mathrm{ft})$ \\
\hline
\end{tabular}

\subsection{EAST AREA}

The steady-state moisture profile representing in situ conditions at the start of operations for the facilities in the 200 East Area is shown in Figure 6-8. Effective saturation contours are closely spaced at sediment interfaces and near the water table.

\subsubsection{6-A-5 Crib}

The simulation for this facility did not encompass the entire time of facility operation because of the complexity of the problem and limitations on computer resources. Time steps as small as 3 seconds were often required. However, the simulation was completed for sufficient time to predict that lateral spreading of effluent will extend to $92 \mathrm{~m}$ (300 ft) beyond the edge of the facility (Figure 6-9). 


\section{EFFECTIVE SATURATION PROFILE}

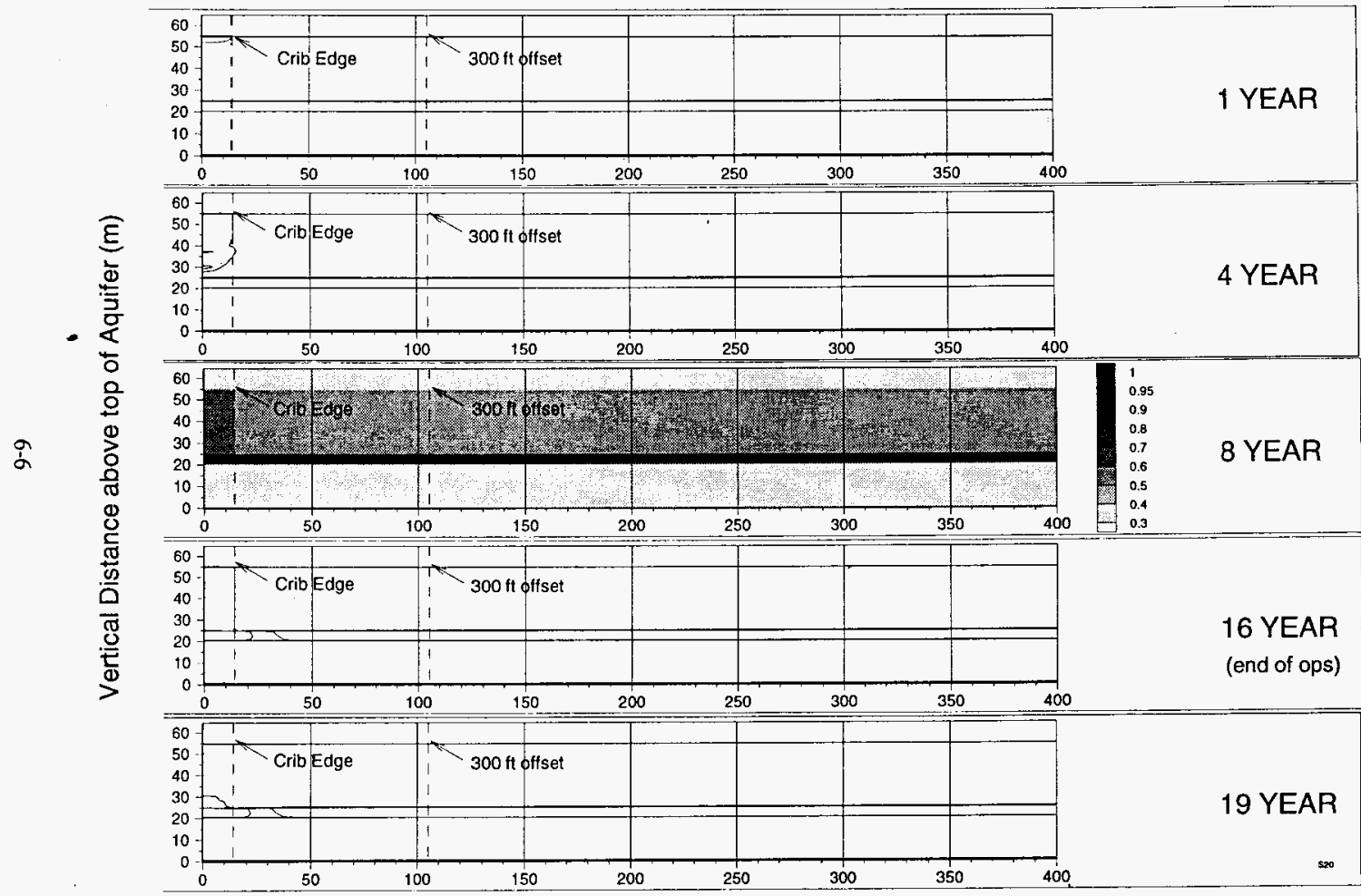

Lateral Distance from Center of Facility $(\mathrm{m})$ 
WHC-SD-LEF-ER-001, Rev. 0

Figure 6-5. Two-Dimensional Moisture Profile for a 20-Ft-Wide Miscellaneous Stream in the 200 West Area.

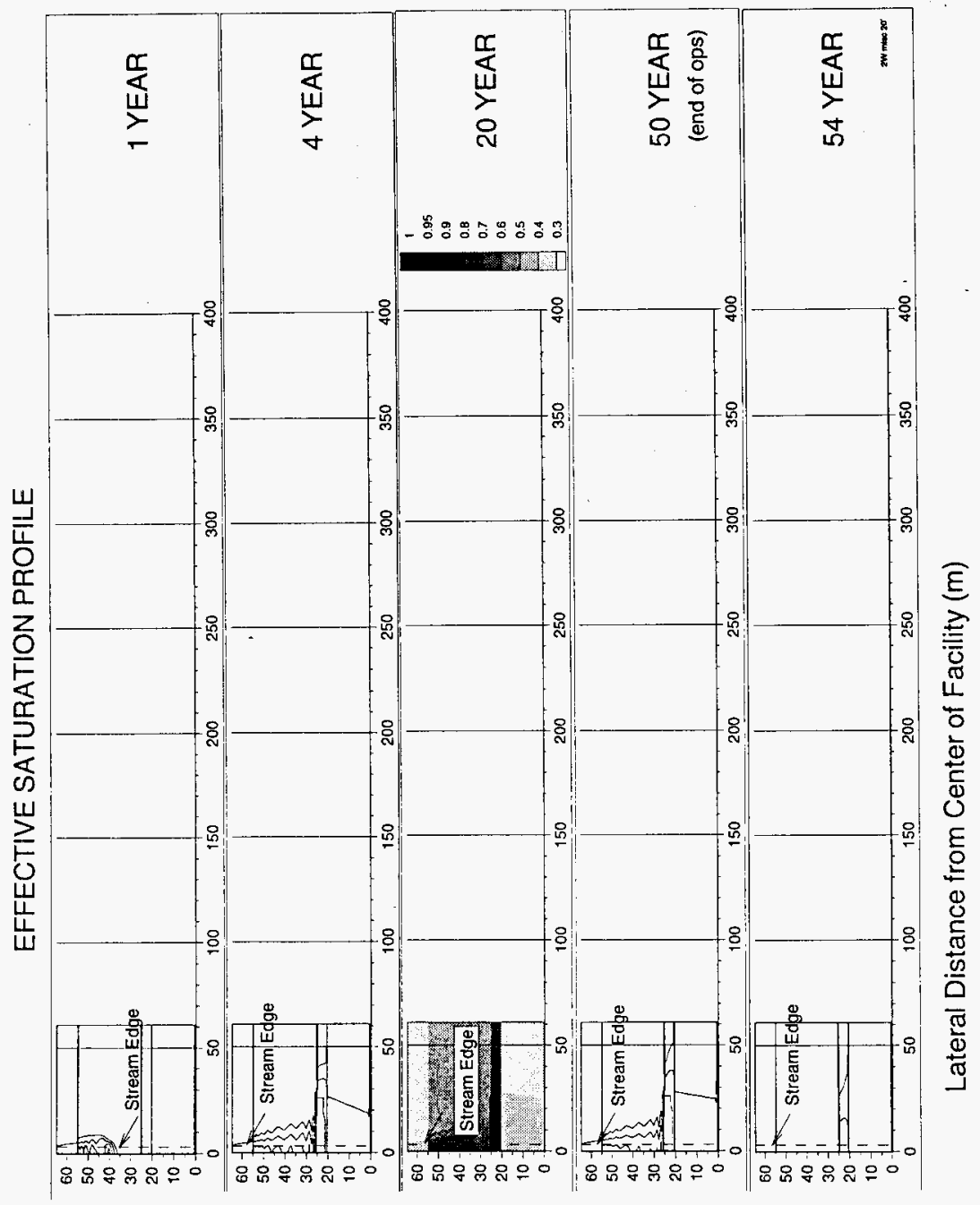

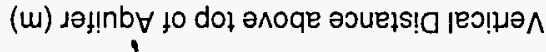


Figure 6-6. Axisymmetric Moisture Profile for a 20-Ft-Diameter Miscellaneous Stream in the 200 West Area.

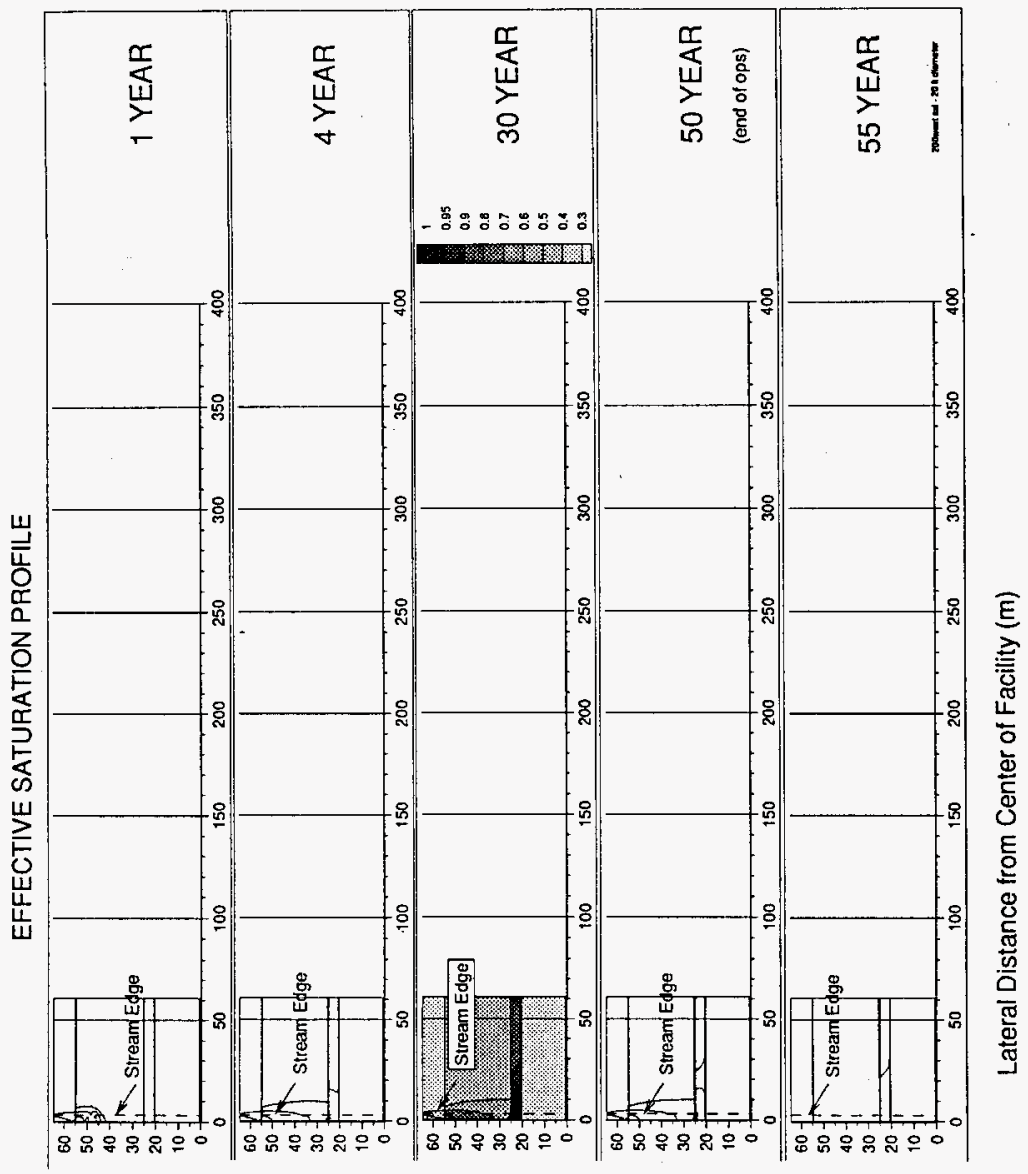

(u) ja!!nb 
WHC-SD-LEF-ER-001, Rev. 0

Figure 6-7. Axisymmetric Moisture Profile for a 4-Ft-Diameter Miscellaneous Stream in the 200 West Area.

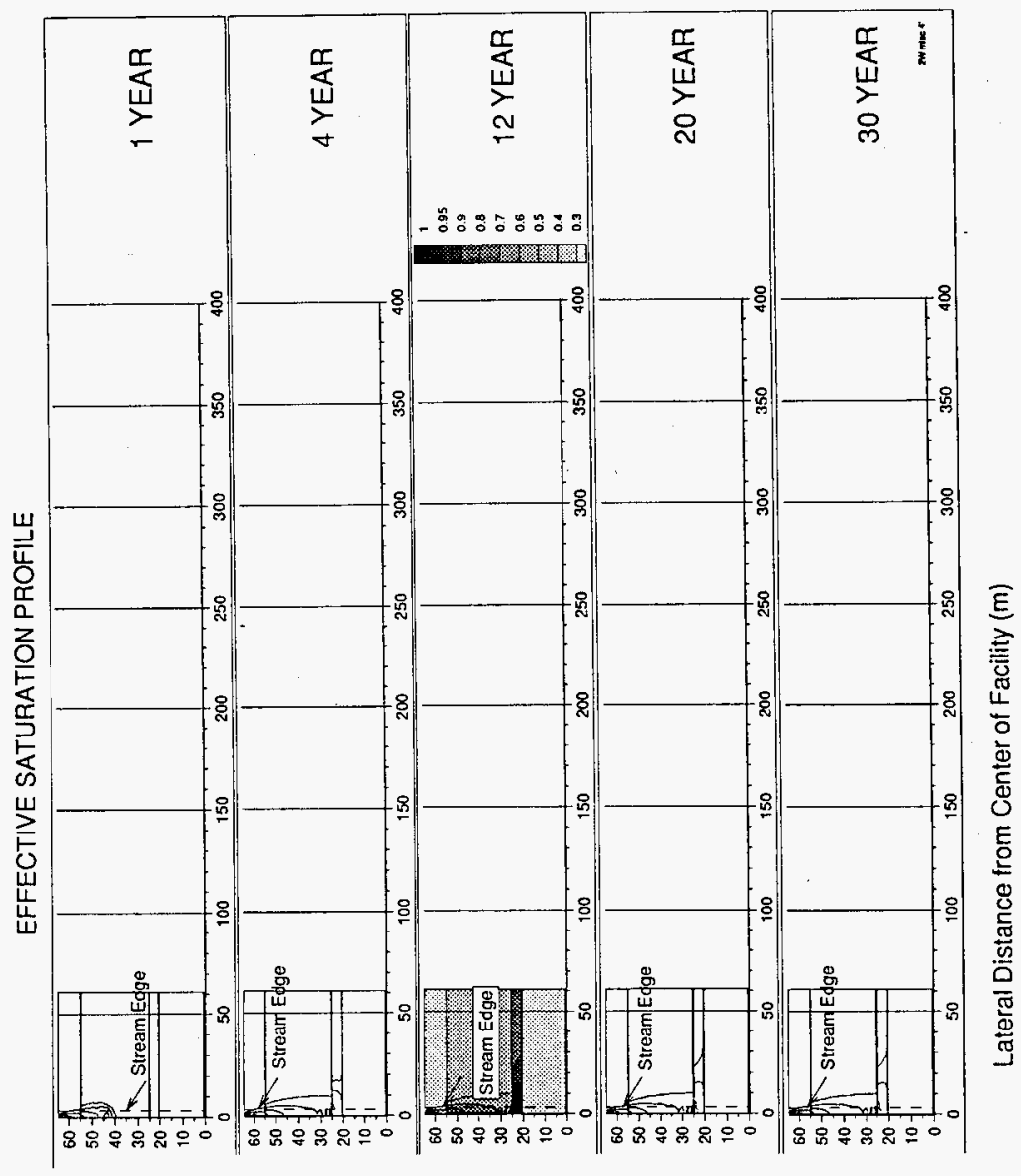

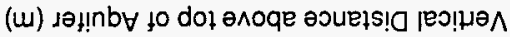


WHC-SD-LEF-ER-001, Rev. 0

Figure 6-8. Pre-operations Moisture Profile for the 200 East Area Model.

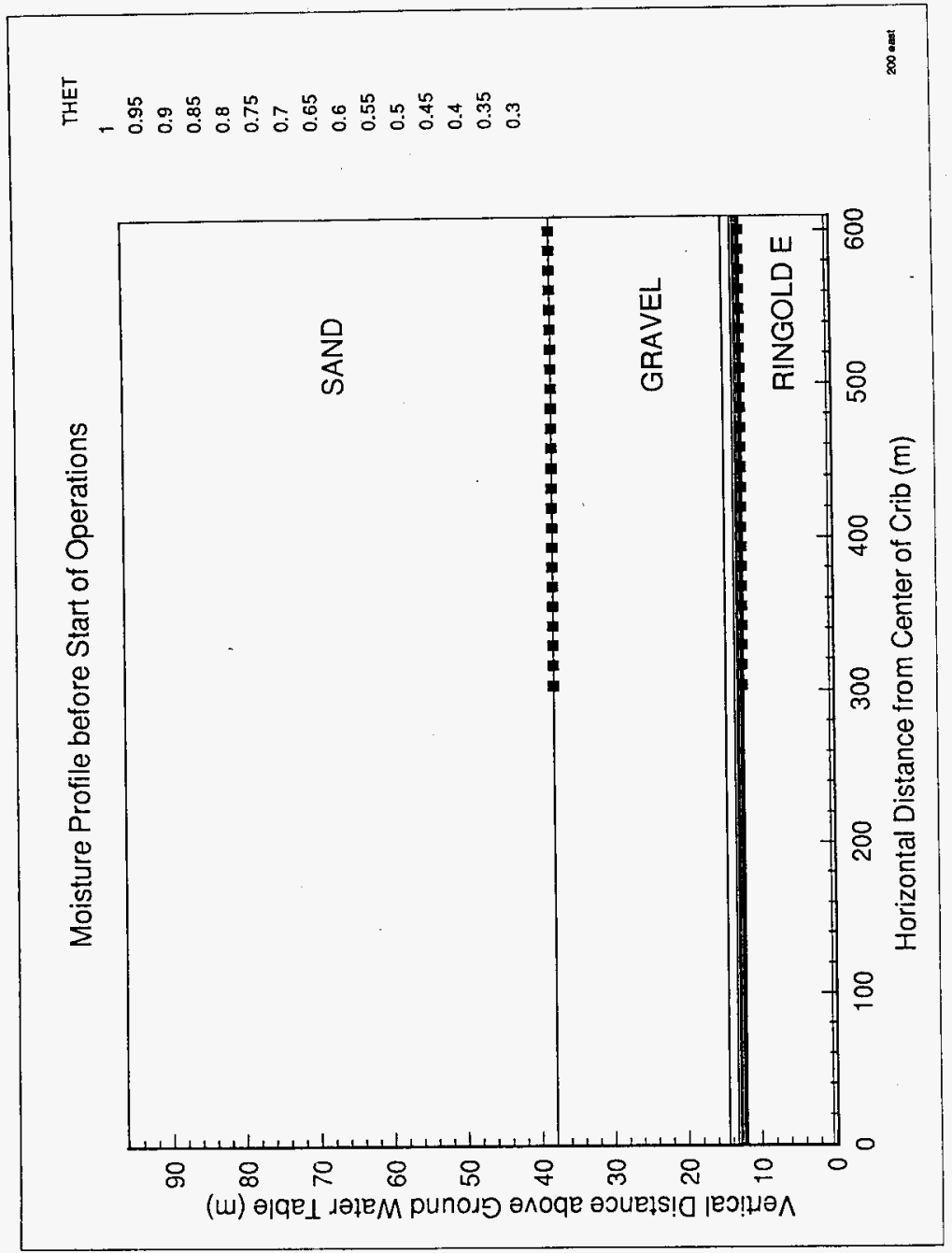


WHC-SD-LEF-ER-001, Rev. 0

Figure 6-9. Moisture Profile for the 216-A-5 Crib.

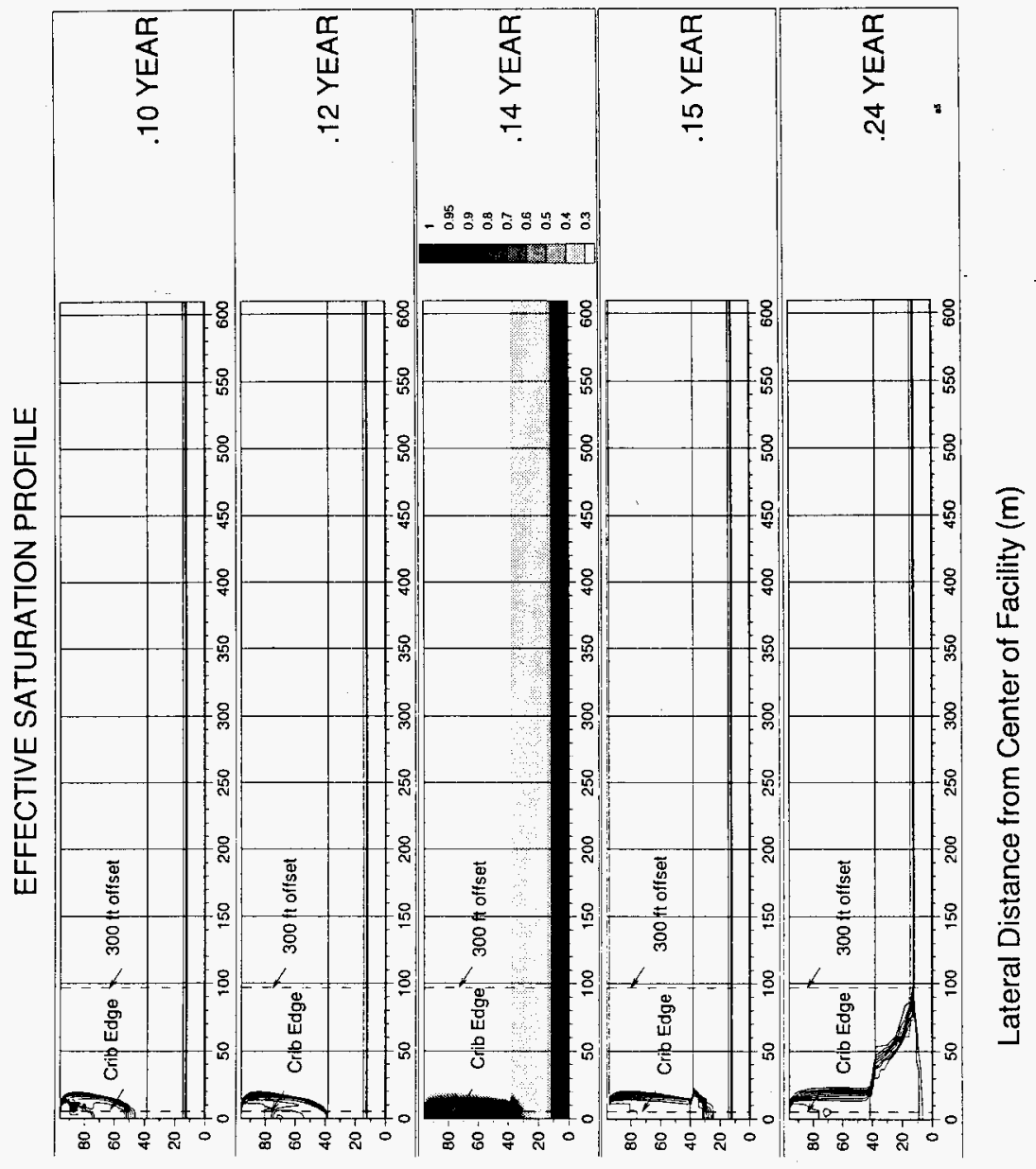

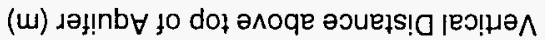


At 0.24 years after operation of this facility began, the effluent is predicted to have migrated nearly to the water table. After the effluent establishes a highly conductive pathway through the. vadose zone, the rate of lateral spreading in the vadose zone would decrease because the effluent would travel most readily through the established pathway.

\subsubsection{6-A-21 Crib}

The model did not encompass the entire time of facility operation because of the complexity of the problem and limitations on computer resources. Time steps as small as 3 seconds were often required. However, the simulation was completed for sufficient time to predict that lateral spreading of effluent will extend to $92 \mathrm{~m}$ ( $300 \mathrm{ft}$ ) beyond the edge of the facility.

At about 0.66 years after operation of the facility began, the effluent is predicted to have reached the water table. After reaching the water table, the rate of lateral spreading in the vadose zone would decrease because the effluent would travel most readily through the highly conductive pathway (Figure 6-10).

\subsubsection{6-A-36A Crib}

The maximum lateral distance at which an increase in effective saturation is predicted is $-38 \mathrm{~m}(125 \mathrm{ft}$ ) (Figure 6-11). This increase is seen at the Hanford gravel/Ringold unit $\mathrm{E}$ interface at 2.9 years after facility startup, or 0.9 years after the end of facility operation. The edge of the facility in the figure is at a distance of $15.24 \mathrm{~m}(50 \mathrm{ft})$ from the left edge of the figure.

Consequently, $-23 \mathrm{~m}$ ( $75 \mathrm{ft}$ ) of lateral spreading from the edge of the facility is predicted.

\subsubsection{Miscellaneous Stream}

The maximum lateral distance at which an increase in effective saturation is predicted is $-60 \mathrm{~m}$ (197 ft) (Figure 6-12). This increase is seen in the Hanford lower gravel unit at 20 to 50 years after facility startup. At these time intervals, the 0.40 effective-saturation contour line has raised slightly above its preexisting position for shorter durations because of the buildup of moisture along the contact with the Ringold Formation. If a less conservative, axisymmetric model were used (like for the 200 West Area) (see Figures 6-5 and 6-6), this apparent effect would likely disappear, resulting in a lateral spread of $\sim 44 \mathrm{~m}(144 \mathrm{ft})$ or less.

\subsection{AREA}

The simulated steady-state moisture profile representing in situ conditions at the start of operations for the facilities of interest in the 300 Area is shown in Figure 6-13. Effective saturation gradients increase (as shown by the closely spaced contours) at the contact between stratigraphic units and near the water table. 
WHC-SD-LEF-ER-001, Rev. 0

Figure 6-10. Moisture Profile for the 216-A-21 Crib.

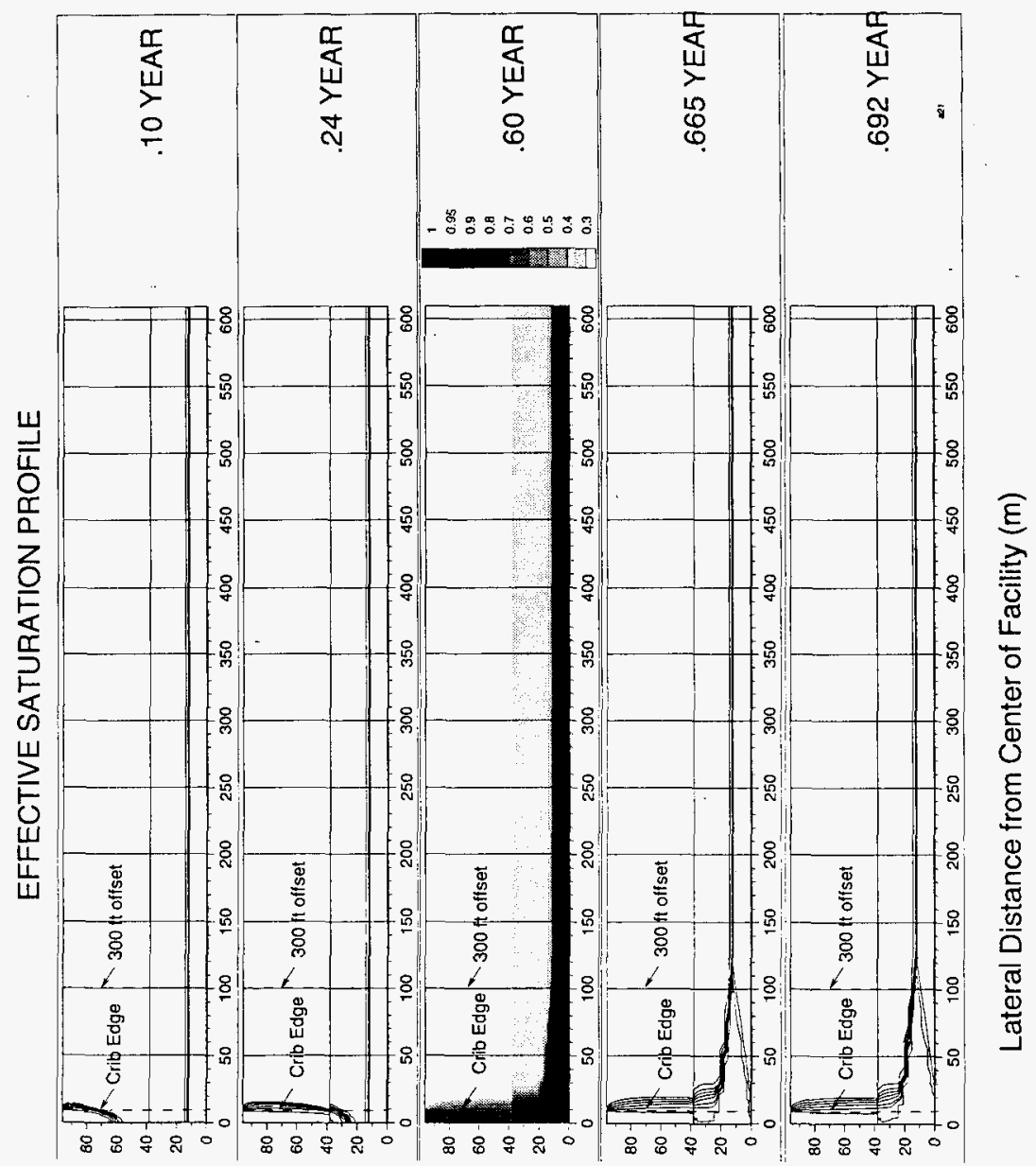

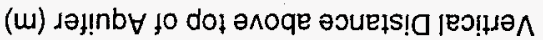


WHC-SD-LEF-ER-001, Rev. 0

Figure 6-11. Moisture Profile for the 216-A-36A Crib.

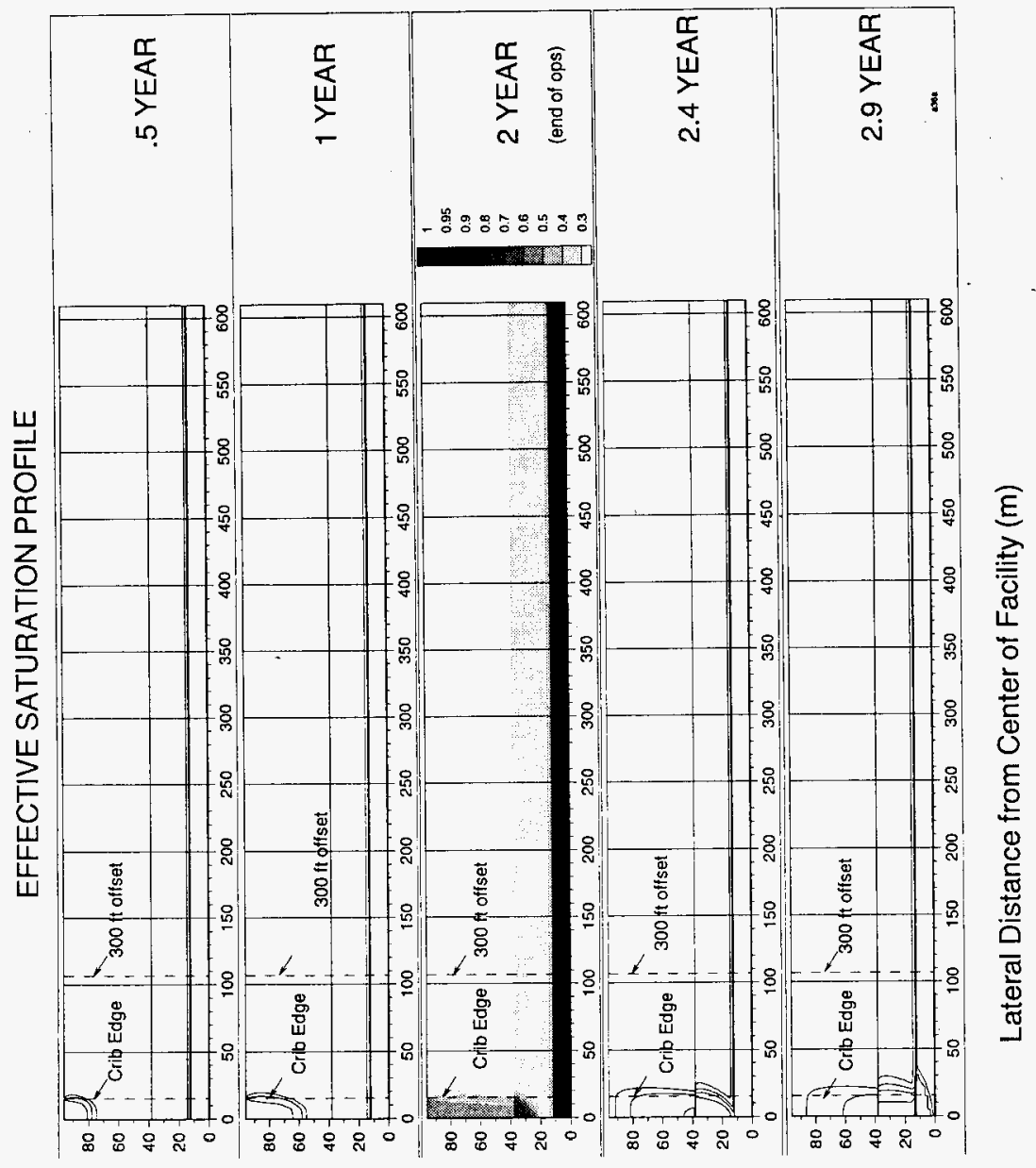

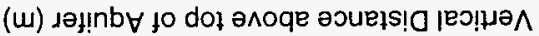


Figure 6-12. Two-Dimensional Moisture Profile for a 20-Ft-Wide Miscellaneous Stream in the 200 East Area.

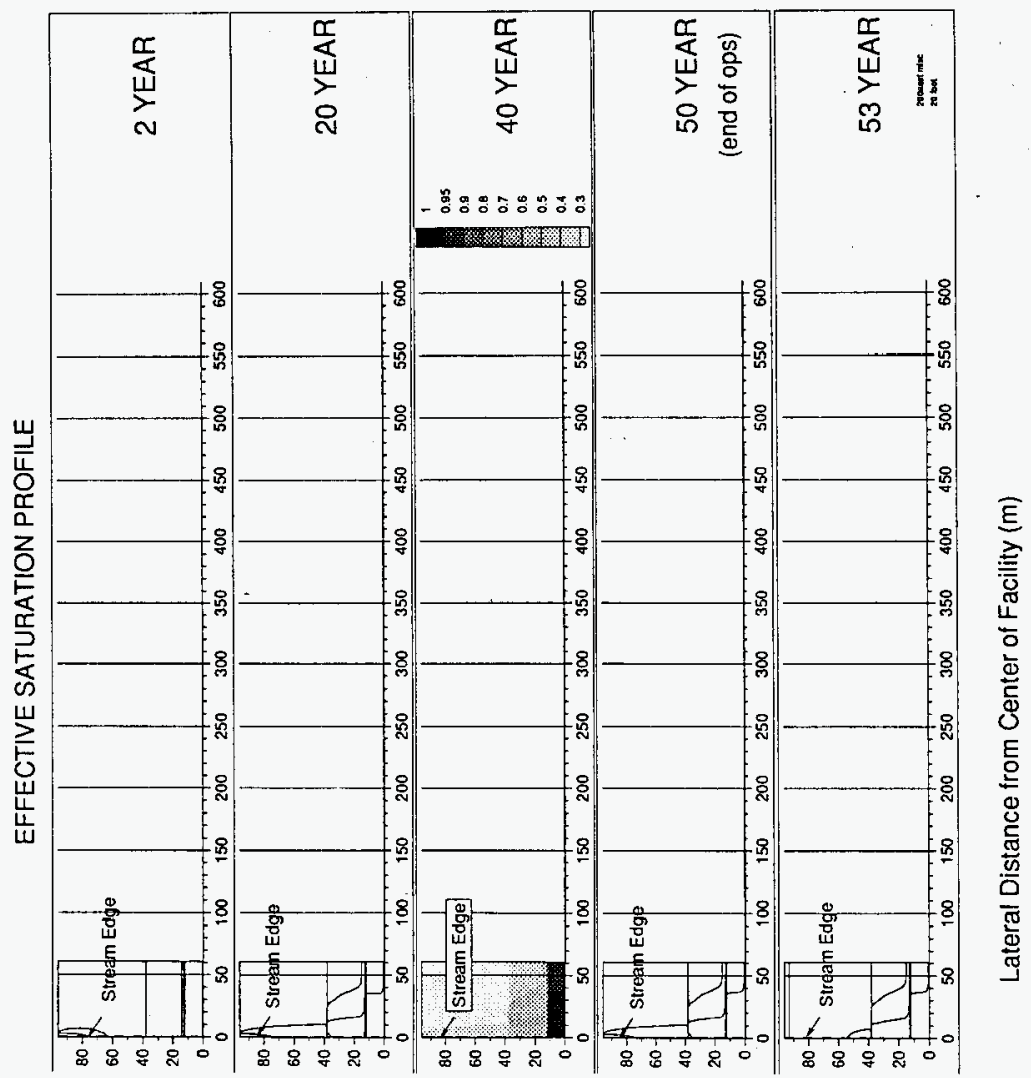

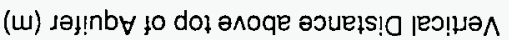




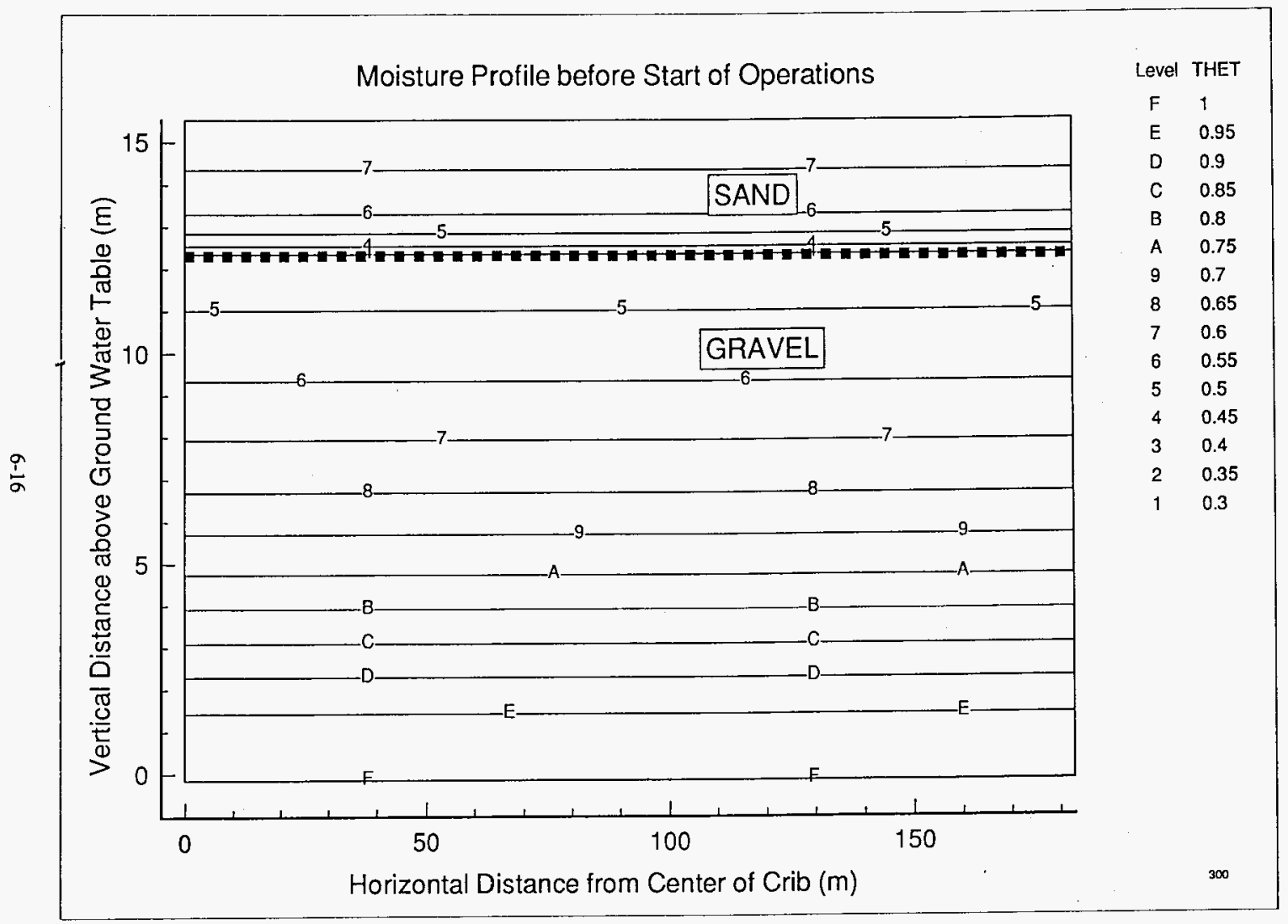




\subsubsection{6-3 Trenches}

The duration simulated for the 316-3 Trenches did not encompass the entire time of facility operations because of the complexity of the problem and limitations on computer resources. Time steps as small as 1 second were often required. However, a sufficient duration was simulated to demonstrate that steady-state conditions were achieved. The lateral spreading of effluent was shown to extend to about $160 \mathrm{ft}(49 \mathrm{~m})$ beyond the edge of the facility (Figure 6-14).

\subsubsection{Miscellaneous Stream}

The maximum lateral distance at which an increase in effective saturation is predicted is abcut $118 \mathrm{ft}(36 \mathrm{~m}$ ) (Figure 6-15). This increase is seen in the upper layer of sand within 5 years after the discharge began. The plots of effective saturation for 5,8 , and 10 years are identical, indicating that steady-state conditions were achieved. After 5 years, the 0.60 effective-saturation contour line had receded slightly from its pre-operational location. A less conservative, axisymmetric model would predict reduced lateral spreading. 
WHC-SD-LEF-ER-001, Rev. 0

Figure 6-14. Moisture Profile for the 316-3 Trenches.

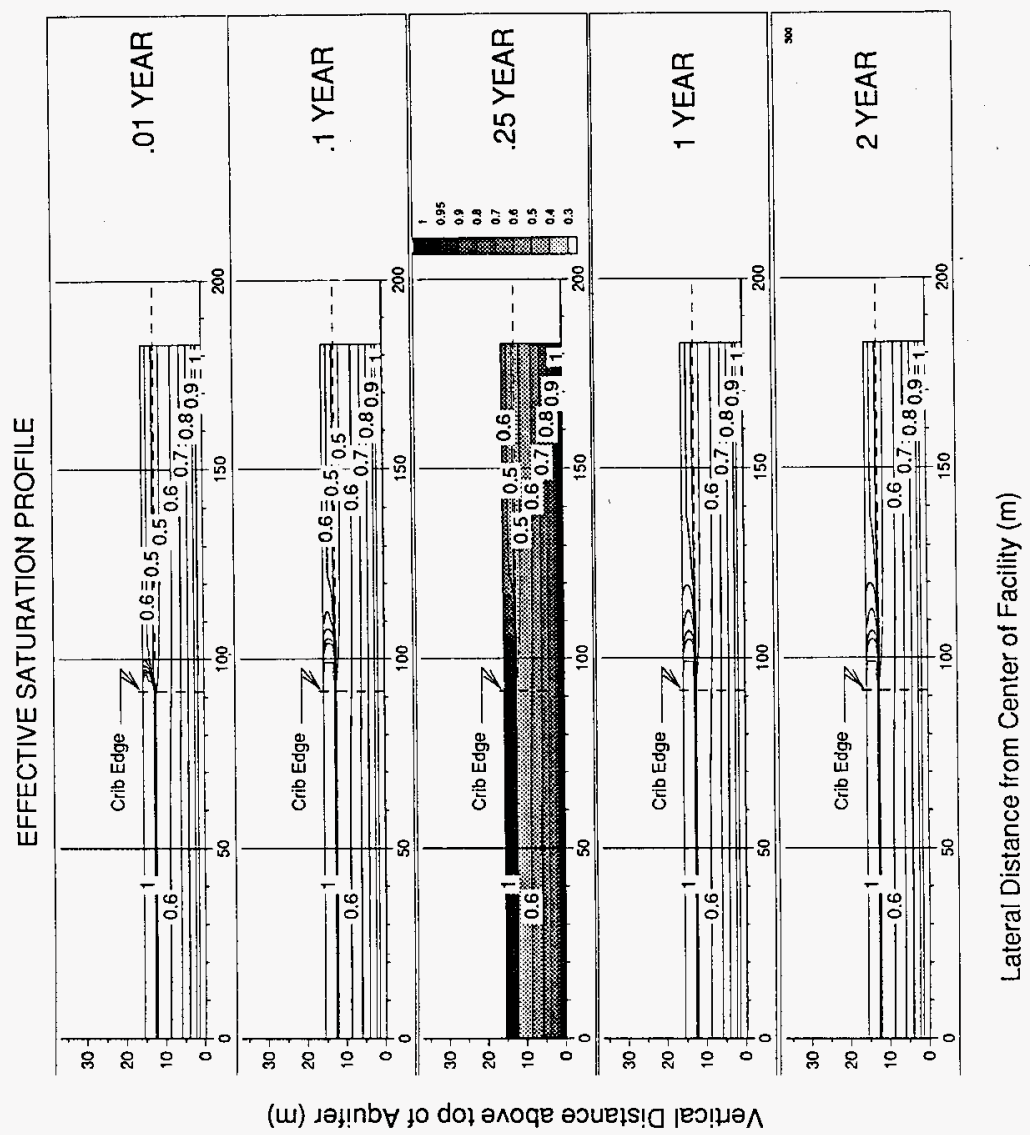




\section{EFFECTIVE SATURATION PROFILE}

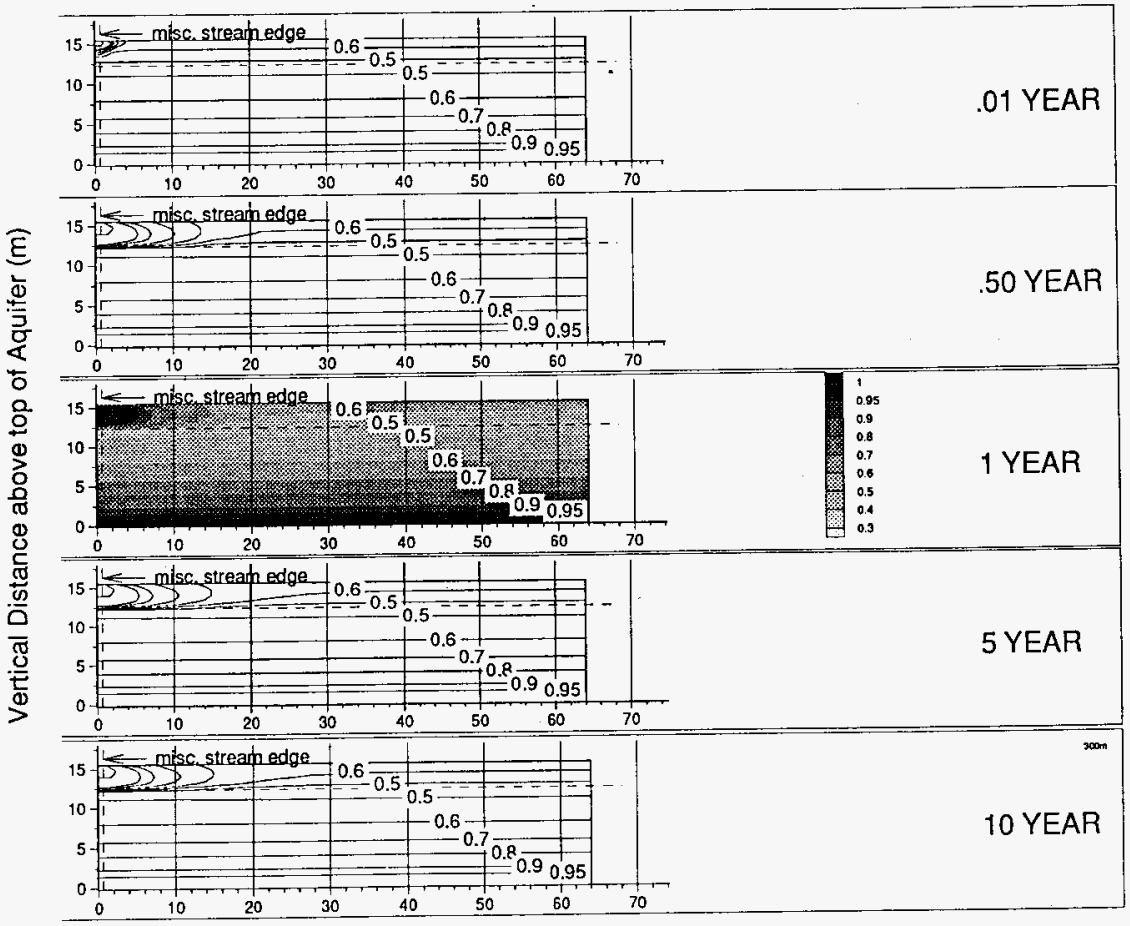

Lateral Distance from Center of Facility (m) 
WHC-SD-LEF-ER-001, Rev. 0

Intentionally left blank. 


\subsection{REFERENCES}

Bjornstad, B. N., 1990, Geohydrology of the 218-W-5 Burial Ground, 200 West Area, Hanford Site, PNL-7336, Pacific Northwest Laboratory, Richland, Washington.

Connelly, M. P., B. H. Ford, and J. V. Borghese, 1992, Hydrogeologic Model for the 200 West Groundwater Aggregate Area, WHC-SD-EN-TI-014, Rev. 0, Westinghouse Hanford Company, Richland, Washington.

Delaney, C. D., K. A. Lindsey, and S. P. Reidel, 1991, Geology and Hydrology of the Hanford Site: A Standardized Text for Use in Westinghouse Hanford Company Documents and Reports, WHC-SD-ER-TI-003, Rev. 0, Westinghouse Hanford Company, Richland, Washington.

DOE, 1988, Consultation Draft, Site Characterization Plan, Reference Repository Location, Hanford Site, Washington, DOE/RW-0164, Vols. 1-9, Office of Civilian Radioactive Waste Management, U.S. Department of Energy, Washington, D.C.

DOE-RL, 1994, Plan and Schedule for Disposition and Regulatory Compliance for Miscellaneous Streams, DOE/RL-93-94, Rev. 1, U.S. Department of Energy, Richland Operations Office, Richland, Washington.

DOE-RL, 1995, Inventory of Miscellaneous Streams, DOE/RL-95-82, Rev. 0, U.S. Department of Energy, Richland Operations Office, Richland, Washington.

DOE-RL, 1996, Miscellaneous Streams Best Management Practices (BMP) Report, DOE/RL-96-40, Rev. 0, U.S. Department of Energy, Richland Operations Office, Richland, Washington.

Ecology and DOE, 1991, Consent Order, Washington State Department of Ecology and U.S. Department of Energy, Washington, D.C.

Fayer, M. J., and T. B. Walters, 1995, Estimated Recharge Rates at the Hanford Site, PNL-10285, Pacific Northwest Laboratory, Richland, Washington.

Gaylord, D. R., and E. P. Poeter, 1991, Geology and Hydrology of the 300 Area and Vicinity, Hanford Site, South-Central Washington, WHC-EP-0500, Westinghouse Hanford Company, Richland, Washington.

Khaleel, R. and E. J. Freeman, 1995, Variability and Scaling of Hydraulic Properties for 200 Area Soils, Hanford Site, Westinghouse Hanford Company, Richland, Washington.

Kincaid, C. T., J. W. Shade, G. A. Whyatt, M. G. Piepho, K. Rhoads, J. A. Voogd, J. H. Westsid, Jr., M. D. Freshley, K. A. Blanchard, and B. G. Lauzon, 1994, Performance Assessment of Grouted Double-Shell Tank Waste Disposal at Hanford, WHC-SD-WM-EE-004, Rev. 1, Westinghouse Hanford Company, Richland, Washington.

Last, G. V., and V. J. Rohay, 1993, Refined Conceptual Model for the Volatile Organic Compounds Arid Integrated Demonstration and 200 West Area Carbon Tetrachloride Expedited Response Action, PNL-8597, Pacific Northwest Laboratory, Richland, Washington. 
Lindberg, J. W., 1995, "300 Area Process Trenches" in Annual Report for RCRA Groundwater Monitoring Projects at Hanford Site Facilities for 1994, DOE/RL-94-136, Rev. O, U.S. Department of Energy, Richland Operations Office, Richland, Washington.

Lindsey, K. A., 1991, Revised Stratigraphy for the Ringold Formation, Hanford Site, South-Central Washington, WHC-SD-EN-EE-004, Rev. 0, Westinghouse Hanford Company, Richland, Washington.

Lindsey, K. A., B. N. Bjornstad, J. W. Lindberg, and K. M. Hoffman, 1992, Geologic Setting of the 200 East Area: An Update, WHC-SD-EN-TI-012, Westinghouse Hanford Company, Richland, Washington.

Lindsey, K. A. and R. B. Mercer, 1994, Geologic Setting of the Low-Level Burial Grounds, WHC-SD-EN-T1-290, Rev. 0, Westinghouse Hanford Company, Richland, Washington.

Lockheed Martin, 1996, Analytical Data Report, for Bechtel Hanford, Inc., Lockheed Martin document file No. 0126596, analyses by Southwest Research Institute, San Antonio, Texas.

Myers, C. W., S. M. Price, J. A. Caggiano, M. P. Cochran, W. J. Czimer, N. J. Davidson, R. C. Edwards, K. R. Fecht, G. E. Holmes, M. G. Jones, J. R. Kunk, R. D. Landon, R. K. Ledgerwood, J. T. Lillie, P. E. Long, T. H. Mitchell, E. H. Price, S. P. Reidel, and A. M. Tallman, 1979, Geologic Studies of the Columbia Plateau: A Status Report, RHO-BWI-ST-4, Rockwell Hanford Operations, Richland, Washington.

Reidel, S. P., K. A. Lindsey, and K. R. Fecht, 1992, Field Trip Guide to the Hanford Site, WHC-MR-0391, Westinghouse Hanford Company, Richland, Washington.

Rohay, V. J., K. J. Swett, and G. V. Last, 1994, 1994 Conceptual Model of the Carbon Tetrachloride Contamination in the 200 West Area at the Hanford Site, WHC-SD-EN-TI-248, Rev. 0, Westinghouse Hanford Company, Richland, Washington.

Runchal, A. K., B. Sagar, and N. W. Kline, 1992, PORFLOW-3: A Mathematical Model for Fluid Flow, Heat, and Mass Transport in Variably Saturated Geologic Media, WHC-EP-0385. Westinghouse Hanford Company, Richland, Washington.

Schalla, R., R. W. Wallace, R. L. Aaberg, S. P. Airhart, D. J. Bates, J. V. M. Carlile, C. S. Cline, D. I. Dennison, M. D. Freshley, P. R. Heller, E. J. Jensen, K. B. Olsen, R. G. Parkhurst, J. T. Rieger, and E. J. Westergard, 1988, Interim Characterization Report for the 300 Area Process Trenches, PNL-6716, Pacific Northwest Laboratory, Richland, Washington.

Slate, J. L., 1996, Report for Virginia Rohay on Boreholes in the 200 West Area Regarding the Nature and Variability of the 'Caliche', Unpublished Report for IT Hanford Company, Richland, Washington.

Swanson, L. C., 1992, Phase I Hydrogeologic Summary of the 300-FF-5 Operable Unit, 300 Area, WHC-SD-EN-TI-052, Westinghouse Hanford Company, Richland, Washington.

Swanson, L. C., 1994, Infiltration Rate and Hydraulic Conductivity Results, Westinghouse Hanford Company Internal Memo 86B20-94-001, Westinghouse Hanford Company, Richland, Washington. 
WHC-SD-LEF-ER-001, Rev. 0

Wright, J., J. L. Conca, and X. Chen, 1994, Hydrostratigraphy and Recharge Distributions from Direct Measurements of Hydraulic Conductivity Using the UFA Method, PNL-9424, Pacific Northwest Laboratory, Richland, Washington. 
WHC-SD-LEF-ER-001, Rev. 0

Intentionally left blank. 
WHC-SD-LEF-ER-001, Rev. 0

APPENDIX A

300 AREA SOIL HYDRAULIC DATA 
WHC-SD-LEF-ER-001, Rev. 0

Intentionally left blank. 
Figure A-1. Particle Size Distribution for Sand Sample BOGL74.

\begin{tabular}{|c|c|c|c|c|c|c|}
\hline \multicolumn{7}{|c|}{$\begin{array}{l}\text { GEOTECHNICAL ENGINEERING LABORATORY } \\
\text { GEL-07 } \\
\text { SIEVE ANALYSIS }\end{array}$} \\
\hline WELL \# & $1301 \mathrm{~N} / 1325-\mathrm{N}$ & DEPTH & $23.0-25.0$ & LAB\# & BOGL74 & WELL \# \\
\hline \multicolumn{2}{|c|}{ TESTED BY PRH } & CONTACT & D. Weeks & PHONE & $372-9326$ & $01 / 09 / 96$ \\
\hline $\begin{array}{l}\text { SAMPLE } \\
\text { WT }(g)\end{array}$ & $\begin{array}{l}\text { SIEVE } \\
\text { SIZE IN. }\end{array}$ & $\begin{array}{c}\text { CUMULATIVE } \\
\text { WEIGHT }\end{array}$ & $\begin{array}{l}\% \text { WEIGHT } \\
\text { RETAINED }\end{array}$ & $\begin{array}{c}\% \\
\text { PASSING }\end{array}$ & $\begin{array}{c}\text { Grain Size } \\
(\mathrm{mm})\end{array}$ & COMMENTS \\
\hline \multirow[t]{6}{*}{$\begin{array}{r}192.7 \\
\end{array}$} & $4^{\prime \prime}$ & 0.0 & 0.0 & 100.0 & 101.6 & \\
\hline & $1.5^{\prime \prime}$ & 0.0 & 0.0 & 100.0 & 38.1 & \\
\hline & $1^{\prime \prime}$ & 0.0 & 0.0 & 100.0 & 25.0 & \\
\hline & $3 / 4^{4}$ & 0.0 & 0.0 & 100.0 & 19.0 & \\
\hline & $3 / 8^{\prime \prime}$ & 4.8 & 2.5 & 97.5 & 9.5 & \\
\hline & $\# 4$ & 6.2 & 3.2 & 96.8 & 4.75 & \\
\hline \multirow{2}{*}{$\begin{array}{l}\text { WT.\#10 } \\
\text { SAMP.(g) } \\
\end{array}$} & $\# 10$ & 6.8 & 3.5 & 96.5 & 2.00 & \\
\hline & $\# 20$ & 9.3 & 4.8 & 91.8 & 0.850 & split \\
\hline \multirow[t]{4}{*}{$\begin{array}{r}192.7 \\
\end{array}$} & $\# 35$ & 12.0 & 6.2 & 90.5 & 0.425 & \\
\hline & $\# 50$ & 17.2 & 8.9 & 87.9 & 0.250 & \\
\hline & $\# 100$ & 41.0 & 21.3 & 75.9 & 0.150 & \\
\hline & $\# 200$ & 132.0 & 68.5 & 30.4 & 0.075 & \\
\hline
\end{tabular}

Sieve Analysis Data for Sample BOGL74

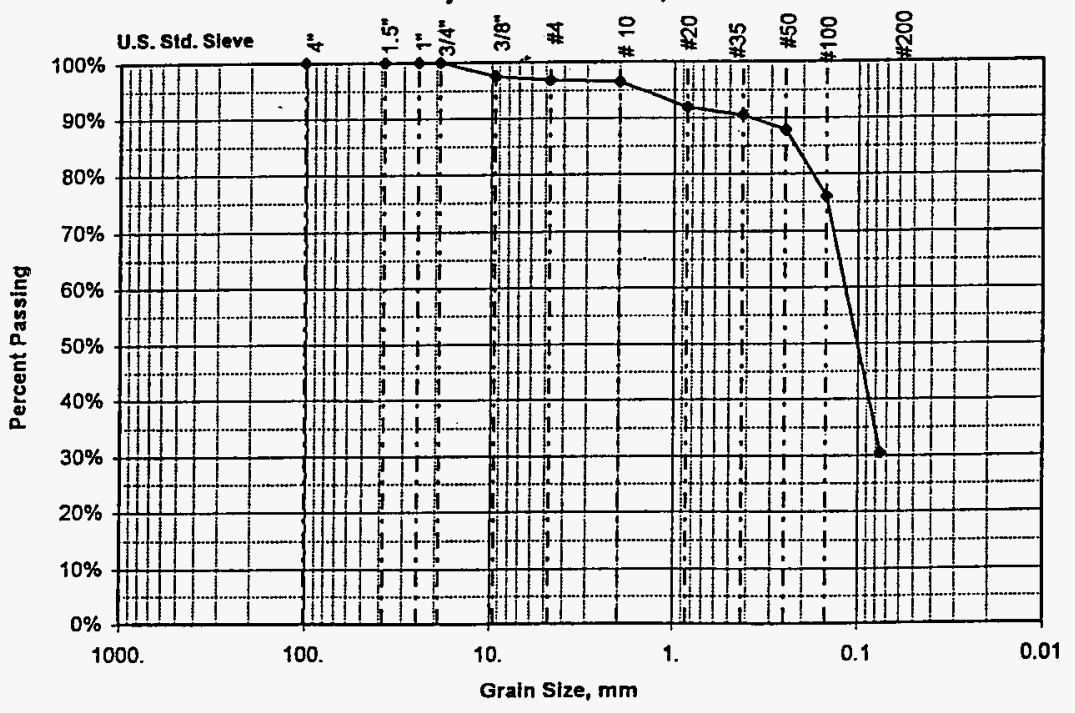


Figure A-2. Particle Size Distribution for Gravel Sample BOGL85.

\begin{tabular}{|c|c|c|c|c|c|c|}
\hline \multicolumn{7}{|c|}{$\begin{array}{l}\text { GEOTECHNICAL ENGINEERING LABORATORY } \\
\text { GEL-07 } \\
\text { SIEVE ANALYSIS }\end{array}$} \\
\hline WELL \# & $1301 \mathrm{~N} / 1325-\mathrm{N}$ & DEPTH & $60.0-63.8$ & LAB\# & BOGL85 & WELL \# \\
\hline TESTED BY & PRH & CONTACT & D. Weeks & PHONE & $372-9326$ & $01 / 09 / 96$ \\
\hline $\begin{array}{l}\text { SAMPLE } \\
W T(g) \\
\end{array}$ & $\begin{array}{c}\text { SIEVE } \\
\text { SIZE IN. }\end{array}$ & $\begin{array}{c}\text { CUMULATIVE } \\
\text { WEIGHT }\end{array}$ & $\begin{array}{l}\text { \% WEIGHT } \\
\text { RETAINED }\end{array}$ & $\begin{array}{c}\% \\
\text { PASSING }\end{array}$ & $\begin{array}{c}\text { Grain Size } \\
(\mathrm{mm})\end{array}$ & COMMENTS \\
\hline \multirow[t]{6}{*}{2259.8} & $4^{4}$ & 0.0 & 0.0 & 100.0 & 101.6 & \\
\hline & $1.5^{\prime \prime}$ & 115.7 & 5.1 & 94.9 & 38.1 & \\
\hline & 11 & 420.2 & 18.6 & 81.4 & 25.0 & \\
\hline & $3 / 4^{n}$ & 571.4 & 25.3 & 74.7 & 19.0 & \\
\hline & $3 / 8^{\prime \prime}$ & 826.1 & 36.6 & 63.4 & 9.5 & \\
\hline & $\# 4$ & 978.1 & 43.3 & 56.7 & 4.75 & \\
\hline \multirow{2}{*}{$\begin{array}{l}\text { WT. } \# 10 \\
\text { SAMP.(g) }\end{array}$} & $\# 10$ & 1147.8 & 50.8 & 49.2 & 2.00 & \\
\hline & $\# 20$ & 35.9 & 14.3 & 42.2 & 0.850 & split \\
\hline \multirow[t]{4}{*}{250.5} & $\# 35$ & 94.8 & 37.8 & 30.6 & 0.425 & \\
\hline & $\# 50$ & 133.7 & 53.4 & 22.9 & 0.250 & \\
\hline & $\# 100$ & 165.4 & 66.0 & 16.7 & 0.150 & \\
\hline & $\# 200$ & 214.9 & 85.8 & 7.0 & 0.075 & \\
\hline
\end{tabular}

Sieve Analysis Data for Sample BOGL85

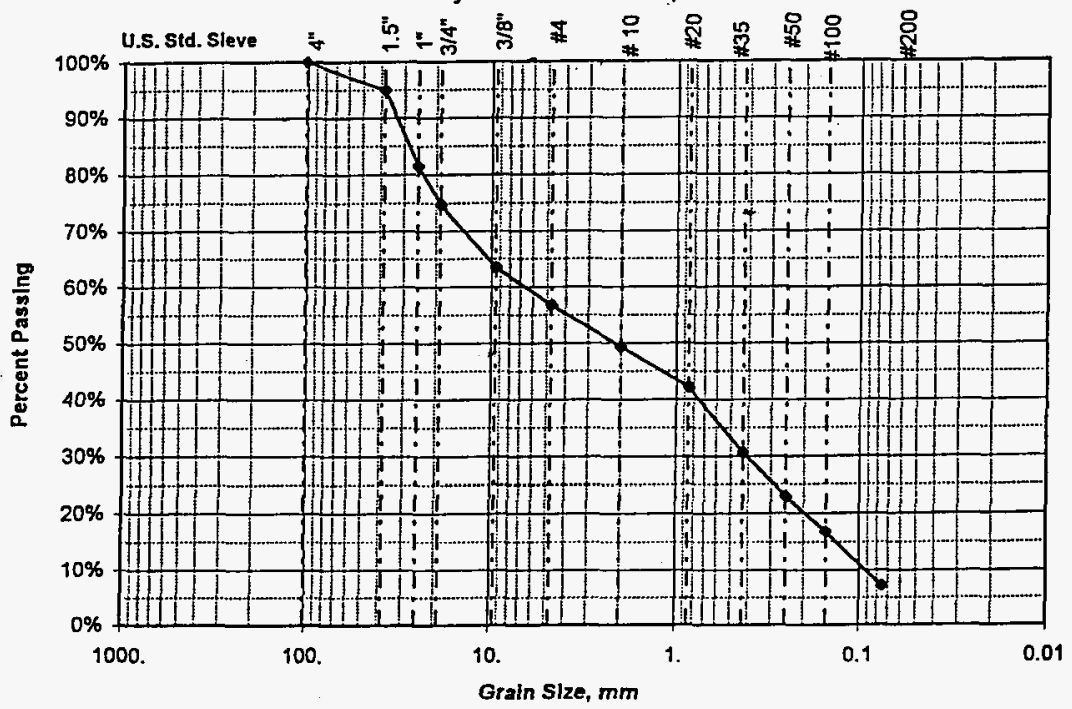

Al dała are accuraiely and completely recorded. The test operator was trained and used calibrated instruments.

Checked By:




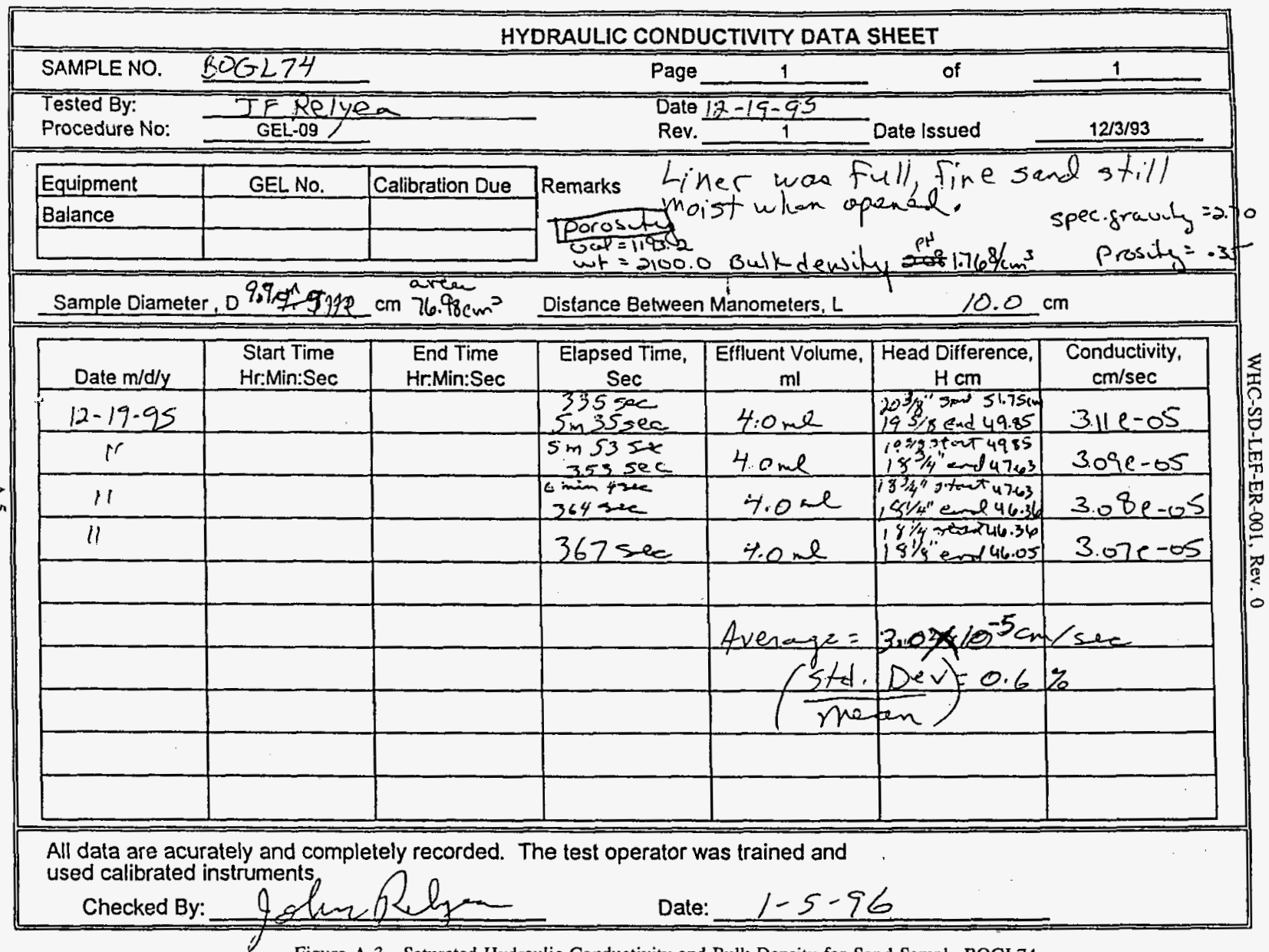

Figure A-3. Saturated Hydraulic Conductivity and Bulk Density for Sand Sample BOGL74. 


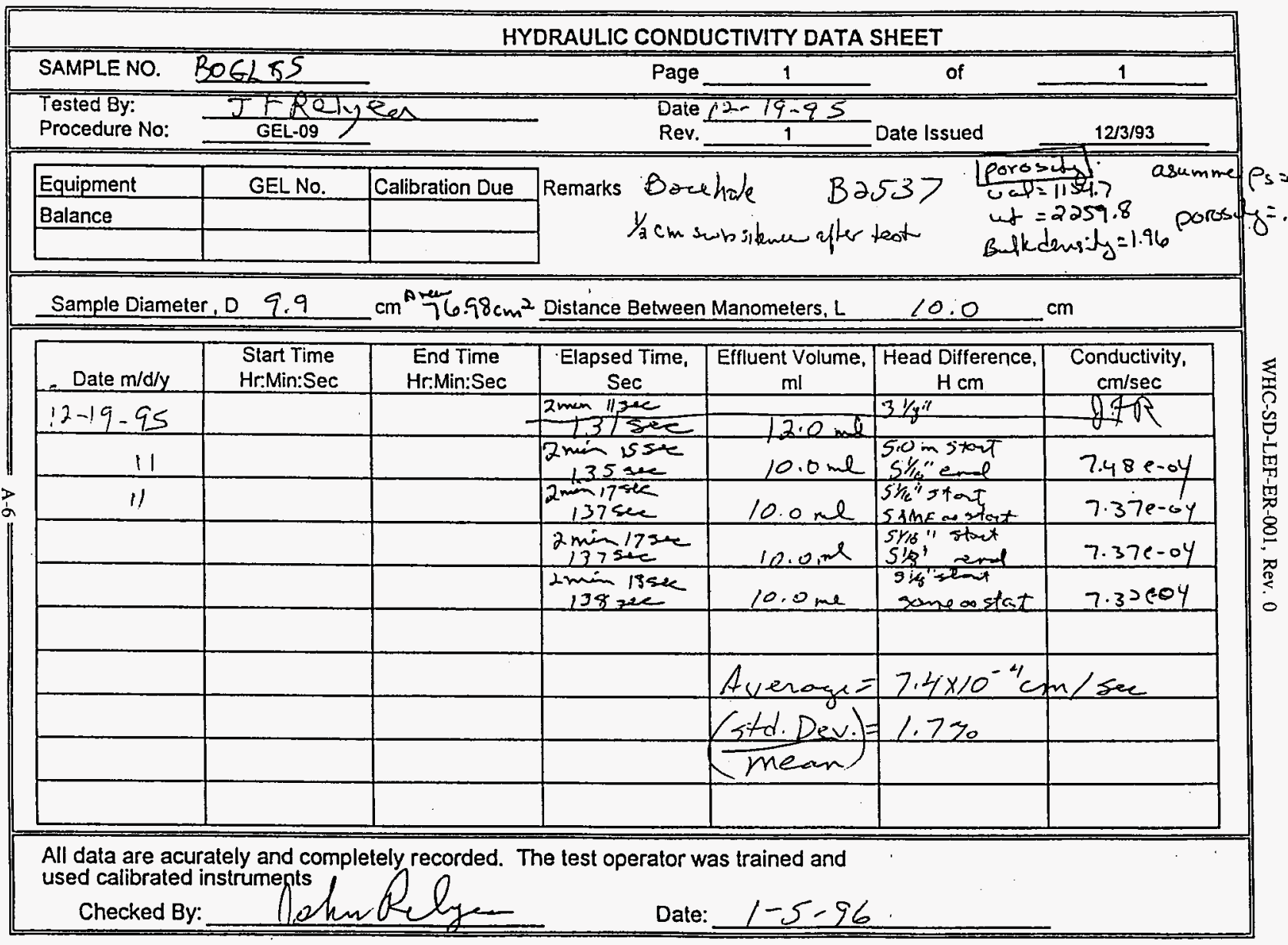

Figure A-4. Saturated Hydraulic Conductivity and Bulk Density for Gravel Sample BOGL85. 